Reprinted from Luyendyk, B. P., Cann, J. R.

Initial Reports of the Deep Sea Drilling Project, Volume XLIX, Washington (U.S. Government Printing Office)

\title{
21. THE PETROLOGY, GEOCHEMISTRY, AND MINERALOGY OF NORTH ATLANTIC BASALTS: A DISCUSSION BASED ON IPOD LEG 49
}

D.A. Wood, ${ }^{1}$ J. Varet, ${ }^{2}$ H. Bougault, ${ }^{3}$ O. Corre, ${ }^{3}$ J.L. Joron, ${ }^{4}$ M. Treuil, ${ }^{4}$ H. Bizouard, ${ }^{5}$ M.J. Norry, ${ }^{6}$ C.J. Hawkesworth, and J.C. Roddick

\begin{abstract}
- Whole-rock geochemical data were obtained for 178 samples selected from the petrologically freshest parts of most of the flow units recovered from the nine holes. These data include 170 major element analyses (XRF) and 174 trace-element analyses (XRF and INAA). We include representative microprobe analyses of the primary minerals and fresh basaltic glasses (where present) in $\mathbf{4 0}$ selected samples. We also present ${ }^{87} \mathrm{Sr} /{ }^{88} \mathrm{Sr}$ ratios for 14 samples selected from the holes at $63^{\circ} \mathrm{N}$.

These analytical data, together with petrographic data obtained from the study of some 500 thin sections, have enabled us to establish a detailed lithostratigraphy for each basement section. -
\end{abstract}

\section{INTRODUCTION}

Leg 49 drilling penetrated basaltic basement in nine holes grouped in three widely spaced areas of the North Atlantic Ocean. The hole locations have enabled us to study the petrological and geochemical variation on several scales: (1) on a regional scale (longitudinally) between the three different areas, viz., $63^{\circ} \mathrm{N}, 45^{\circ} \mathrm{N}$, and $36^{\circ} \mathrm{N}$; (2) within a single area, using other published data from the areas concerned - e.g., comparing the data from Holes 407 , 408 , and 409 with data from Iceland, the Reykjanes Ridge, and Leg 38 (northeast of Iceland) (Figure 1); (3) within a single hole to establish the degree of vertical variation in the basaltic crust on a local scale. Petrological and geochemical studies on all three scales contribute significantly to our knowledge of the nature of crustal Layer 2 in the Atlantic Ocean.

Previous research has suggested that the Mid-Atlantic Ridge (MAR) consists of "normal ridge segments" together with "anomalous hot spot areas" (viz., Iceland and the Azores) and transitional zones between them (e.g., the Reykjanes Ridge and the MAR to the south of the Azores, i.e., $35^{\circ}$ to $39^{\circ} \mathrm{N}$ ) (Morgan, 1971; Vogt, 1972; Schilling, 1975). It has been proposed that temporal fluctuations in hot-spot activity may account for the large longitudinal and transverse geochemical variations in the crustal rocks of the North Atlantic Ocean (Vogt, 1972; Schilling and Noe-Nygaard, 1974; White et al., 1975). The is 2 .

'Bedford College, University of London, England. Present address $2 \mathrm{D}$

France.

${ }^{3}$ C.O.B., B.P. 337, 29273 Brest, France.

"Laboratoire Pierte Sue, groupe des Sciences de la Terre CEN Saclay, Gif/Yvette, France.

sUniversité de Paris Sud, Bat. 510, 91405 Orsay, France.

'Dept. of Earth Sciences, University of Leeds, England.

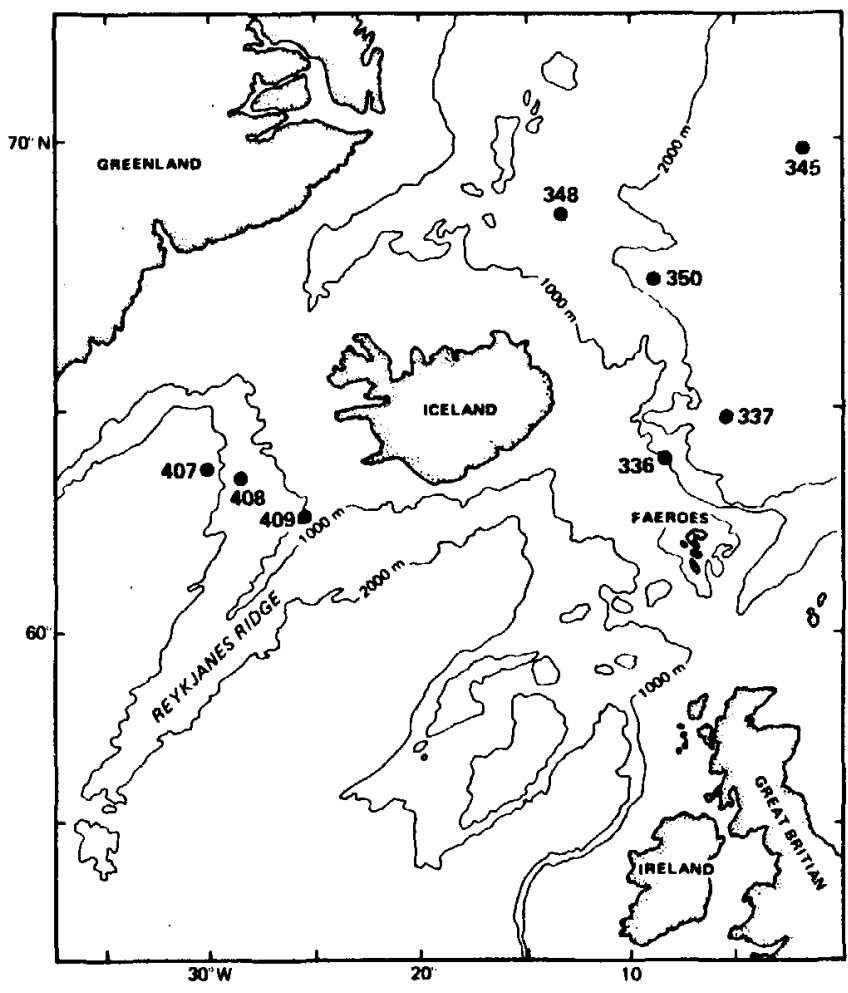

Figure 1. Map showing the locations of Sites 407, 408, and 409 with respect to the Reykjanes Ridge. Some DSDP Leg 38 sites around Iceland are included.

positioning of the Leg 49 sites was influenced by these concepts.

Sites 407 to 409 were placed on an east-west transect in order to investigate the nature of activity at a single segment of the Reykjanes Ridge from pre-Miocene (supposedly preceding the hot-spot influence) to the present. Similarly, Sites 411 to 413 were placed (together with Sites 332 to 335 
of Leg 37) in order to elucidate the nature of activity with time at the $36^{\circ}$ to $37^{\circ} \mathrm{N}$ segment of the MAR. Although dredged basalts from the MAR at $45^{\circ} \mathrm{N}$ show considerable petrological and geochemical diversity (Aumento et al., 1971), this area was selected to investigate longitudinal variation because of its position between Iceland and the Azores on a bathymetrically normal segment of the MAR (supposedly uninfluenced by hot-spot activity).

We will present a hole-by-hole account of the petrology, mineralogy, and geochemistry of the three areas. Then we will compare the areas and offer a general discussion on petrogenesis of North Atlantic basalts.

\section{SAMPLING AND ANALYTICAL TECHNIQUES}

Thin sections were made on board from almost all the cores recovered (about 500 sections); this permitted a petrographic distinction of flow units. Additional thin sections, made subsequently, have more accurately defined the petrographic boundaries. Samples for systematic geochemical analyses were taken from most flow units (see Appendices I, II, and III at the back of this volume). Preliminary geochemical results were used to establish the main lithologic boundaries and to select 48 samples from the major rock types for complete analyses of the rare-earth elements (REE) and for microprobe studies. Fourteen samples from Holes 407 to 409 were selected from those analyzed for REE to be analyzed for $\mathrm{Sr}$ isotopes. Fresh basaltic glass was sampled where present, and has been analyzed by the microprobe.

The major-element oxides and the elements $\mathrm{Ti}, \mathrm{V}, \mathrm{Cr}$, $\mathrm{Mn}, \mathrm{Fe}, \mathrm{Co}, \mathrm{Ni}, \mathrm{Rb}, \mathrm{Sr}, \mathrm{Y}, \mathrm{Zr}$, and $\mathrm{Nb}$ have been analyzed by $\mathrm{X}$-ray fluorescence (XRF) at Brest (Bougault et al., in press). The elements $\mathrm{Sc}, \mathrm{Co}, \mathrm{Ni}, \mathrm{Rb}, \mathrm{Zr}, \mathrm{Sb}, \mathrm{Cs}, \mathrm{Ba}, \mathrm{La}$, $\mathrm{Ce}, \mathrm{Eu}, \mathrm{Tb}, \mathrm{Hf}, \mathrm{Ta}, \mathrm{Th}$, and $\mathrm{U}$ have been analyzed by instrumental neutron activation (INAA) at Saclay (Treuil et al., 1972; Chayla et al., 1973). The elements Ce, Nd, Sm, $\mathrm{Eu}, \mathrm{Gd}, \mathrm{Tb}, \mathrm{Tm}, \mathrm{Yb}, \mathrm{Lu}, \mathrm{Hf}$, and $\mathrm{Th}$ have been analyzed by INAA at Bedford College, London (Wood, 1976).

$\mathrm{Sr}$ isotopes have been analyzed by mass spectrometry at Leeds. To overcome the effects of sea-water/rock interaction on the $\mathrm{Sr}$ isotopes, the leaching technique of O'Nions and Pankhurst (1976) has been used. Three hundred $\mathrm{mg}$ of rock powder were placed with $10 \mathrm{~cm}^{3}$ of $6 \mathrm{M}$ hydrochloric acid in an autoclave overnight. The residue (which X-ray diffraction analyses have shown to consist almost totally of clinopyroxene, other phases being dissolved) was washed and centrifuged four times.

Microprobe analyses were carried out using the energy-dispersive system (EDS) at Cambridge (Wood) (Reed and Ware, 1975) and the wave-dispersive system (WDS) (Cameca type, Camebax microprobe) at Orsay (Bizouard) (Rucklidge et al., 1970). The two microprobe studies were complementary: the EDS was used to establish the general range of phenocryst compositions in most of the lithostratigraphic units, i.e., by making few (about 25) analyses in many samples; the WDS was used for detailed study of four samples from the $36^{\circ} \mathrm{N}$ holes and other samples from this area.

\section{MAR 63ํN: HOLES 407, 408, AND 409 - GENERAL}

Figure 1 is a map of the North Atlantic Ocean in the vicinity of Iceland, and shows the locations of the Leg 49 sites and some of the Leg 38 sites to the northeast of Iceland. The east-west transect of Leg 49 was at $63^{\circ} \mathrm{N}$, to correspond to the midpoint of the geochemical gradient suggested by dredged rocks from the Reykjanes Ridge (Schilling, 1973; Hart et al., 1973; Sun et al., 1975). It is questionable whether a gradient based on single samples collected at widely spaced intervals on a longitudinal traverse would still be clear after more detailed sampling at a particular latitude. Recent studies in Iceland have shown that a significant range of basalt types (i.e., with different ratios of a hygromagmatophile element [HYG element in this study] versus an element with a higher bulk partition coefficient [D] for peridotitic and basaltic mineral assemblages [but still with D significantly less than 1]) may be erupted from a single eruptive complex or fissure swarm (Treuil and Varet, 1973; Wood, 1976; Sigvaldason et al., 1976). This results in substantial variation in the basalt types with depth at any one locality. The presence of basalts with very low HYG-element ratios, ${ }^{7}$ together with basalts with high HYG-element ratios, also indicates that the geochemical gradient may not be as simple as was originally suggested.

The relatively good penetration and recovery from the three holes, especially Holes 407 and 409 , has revealed that various petrographic basalt types exist within a single hole (Figure 2). To emphasize the scale of the petrographic and geochemical variations, each hole will be considered in more detail.

\section{Hole 407}

This hole is on magnetic anomaly 13 (about 35 to 40 m.y.) in a water depth of 2472 meters; the hole penetrated 154.5 meters into basaltic basement. This location is to the south of the minimum bathymetric anomaly of the Iceland-Greenland Ridge (Figure 1), and was selected to correspond to the minimum of proposed mantle plume activity (Vogt, 1972).

Detailed descriptions of each flow unit (Site Report chapter, Site 407) have enabled four main lithostratigraphic units to be defined by petrographic and geochemical data (Figure 3 ). The boundary between Units 2 and 3 corresponds to a major change in magnetic polarity.

Unit 1: This upper unit is a ferrobasalt (about $15 \mathrm{wt} . \%$ $\mathrm{FeO} ; 5$ wt.\% $\mathrm{MgO}$ ) which consists of four lava flows interlayered with sediment. The upper two flows are sparsely plagioclase and olivine ${ }^{8}$ microporphyritic, and the

${ }^{7}$ E.g., $(\mathrm{Ce} / \mathrm{Yb}) \mathrm{N}<0.5$, where $N$ denotes that the elements have been normalized by chondrite values (Nakamura. 1974) similar to basalts erupted from the "normal" mid-ocean ridge segments - i.e., MORB (Hart, et al., 1972; Frey et al., 1974) in the active zones of Iceland (O'Nions et al., 1976) and even at the tip of the Reykjanes Peninsula (Wood, in press).

${ }^{8}$ Olivine is totally replaced by smectite in all the holocrystalline basalts in this hole. 


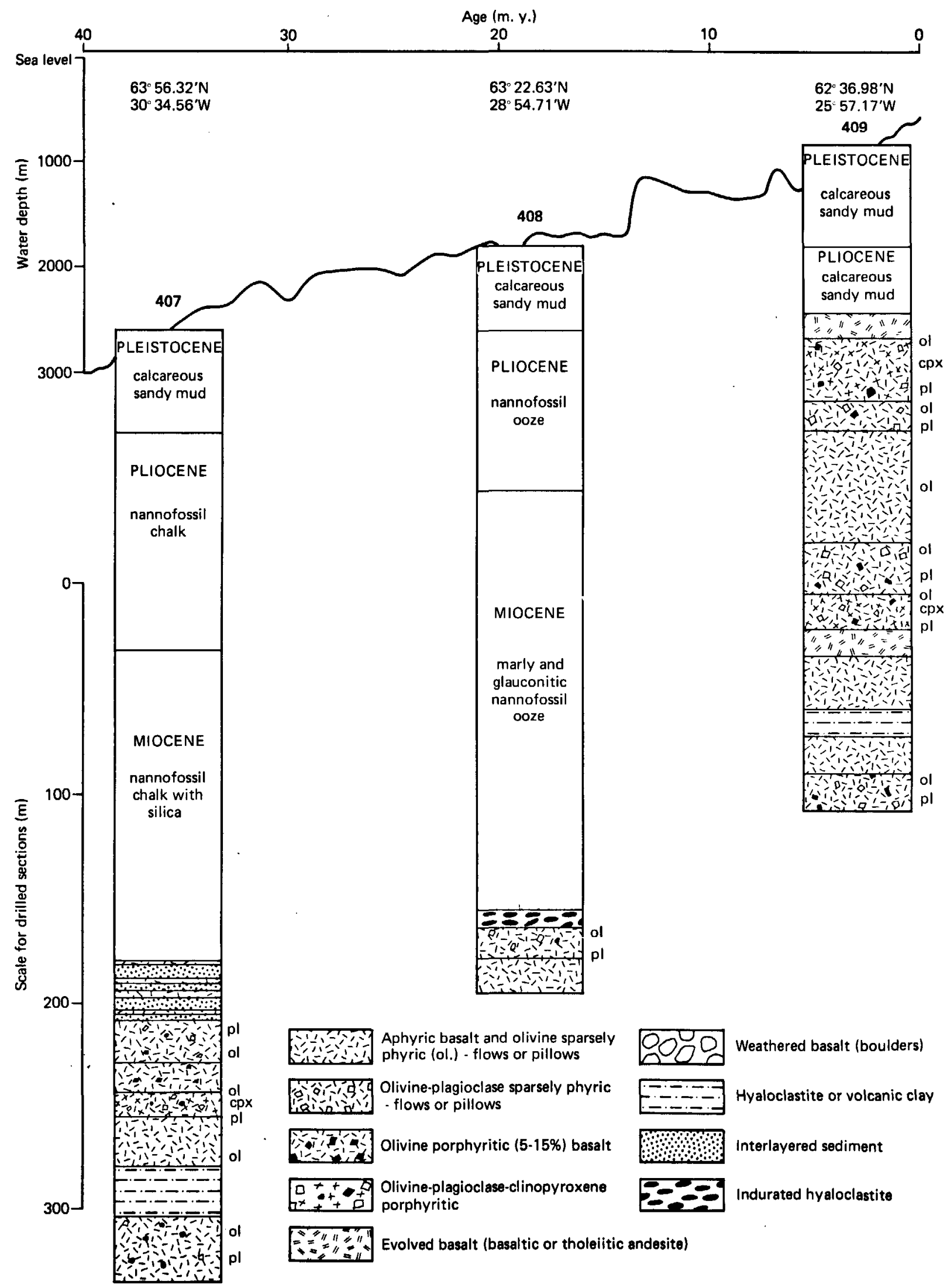

Figure 2. Simplified stratigraphic sections of Sites 407,408 , and 409 , reported on the age-depth curve, with seafloor topography along track of Glomar Challenger reconstructed from echo sounder records (W. A. Duffield, this volume). Main petrographic units of the basement are distinguished. 


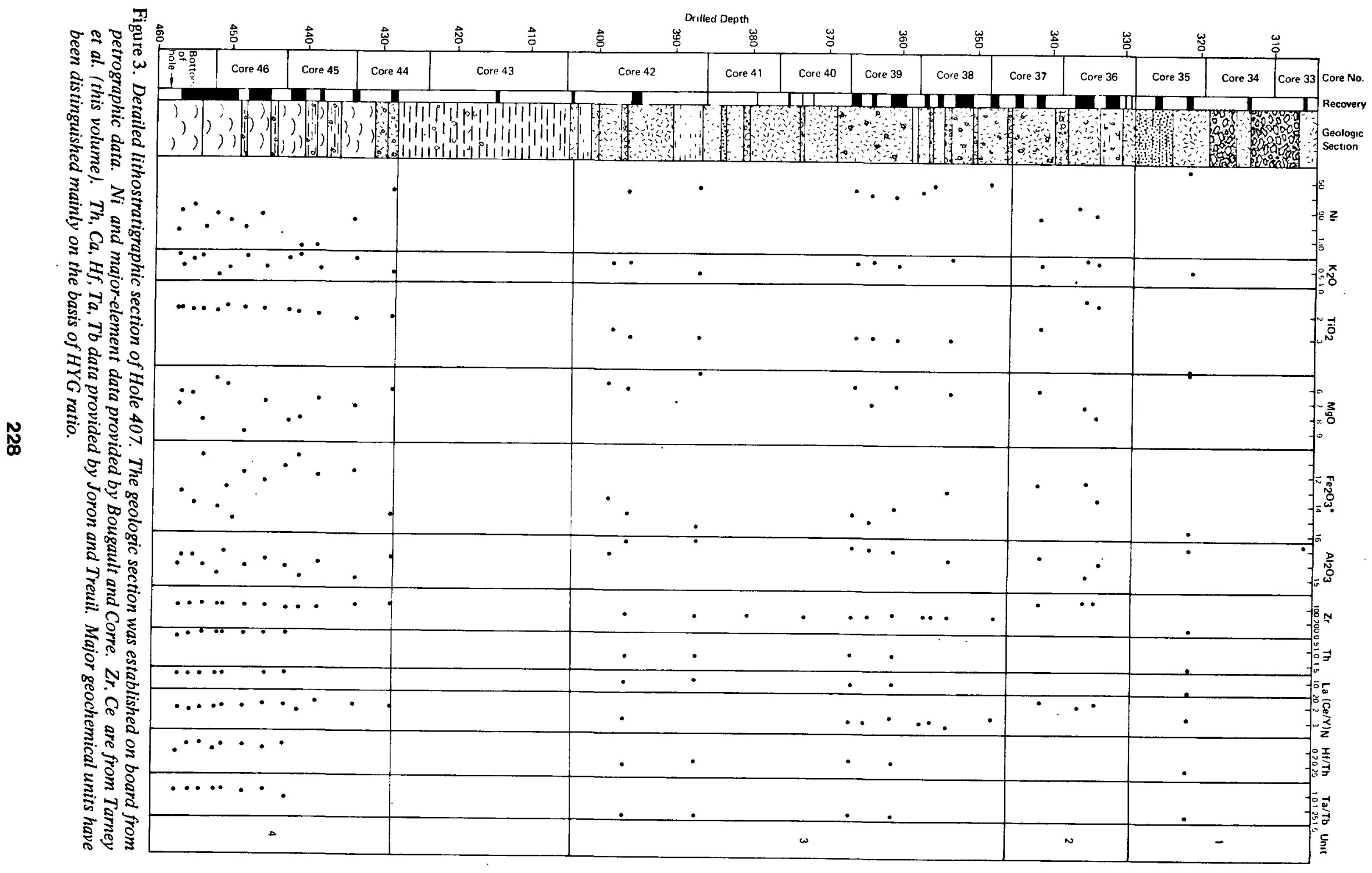


lower two are aphyric. The evolved nature of this ferrobasalt is also evident from the high $\mathrm{Ti}, \mathrm{K}$, and HYG-element concentrations. The high values of the HYG-element ratios $\mathrm{Ce} / \mathrm{Y}, \mathrm{Ta} / \mathrm{Tb}$, and $\mathrm{Th} / \mathrm{Hf}$ cannot be attribted to its evolved nature, because these ratios cannot be significantly modified by closed-system crystal fractionation of phenocryst phases present in basaltic liquids (Treuil and Varet, 1973; Treuil and Joron, 1975) except by unrealistic proportions of clinopyroxene or garnet fractionation.

Unit 2: This unit consists of two flows each about 5 meters thick. The upper flow is plagioclase and olivine glomerophyric with a sub-ophitic texture (Plate 1, Figure 1 ), and is relatively magnesian. The plagioclase phenocrysts are zoned with very calcic cores (up to Ang4) (Table 1). Clinopyroxene microphenocrysts have a relatively magnesian composition (Table 2), reflecting the rather primitive nature of the basalt. The lower flow is slightly more evolved, and has high $\mathrm{Fe}$ and $\mathrm{Ti}$ concentrations. Both flows have the same HYG-element ratios, which are lower than those of the other units sampled in this hole.

Unit 3: This unit consists of 12 flows overlying a 25-meter-thick sedimentary unit. These flows vary from sparsely plagioclase, olivine, and augite phyric to aphyric. The plagioclase and augite microphenocrysts have a relatively constant composition (about $\mathrm{An}_{76}$; ionic $\mathrm{Mg} / \mathrm{Mg}$ $+\mathrm{Fe}=0.74$ to 0.76 , respectively, Tables 1 and 2 ). There is slight geochemical variation within this unit, notably an inverse correlation between $\mathrm{Fe}_{2} \mathrm{O}_{3} *$ (* refers to total $\mathrm{Fe}$ as either $\mathrm{FeO}$ or $\mathrm{Fe}_{2} \mathrm{O}_{3}$ ) and $\mathrm{Al}_{2} \mathrm{O}_{3}$ (Figure 3), which can probably be explained in terms of the uneven distribution of plagioclase phenocrysts. The flows of this unit have the same HYG-element ratios as Unit 1 , but are generally more magnesian.

Unit 4: This consists of a pillow complex of olivine, and olivine and plagioclase phyric basalt with common chilled glass margins and clastic zones. The glass is mainly altered

TABLE 1

Representative Plagioclase Analyses (Hole 407), Normalized to Eight Oxygens

\begin{tabular}{|c|c|c|c|c|c|c|c|c|}
\hline $\begin{array}{c}\text { Sample } \\
\text { (Interval in } \mathrm{cm} \text { ) }\end{array}$ & $\begin{array}{l}0 \\
0 \\
0 \\
0 \\
0 \\
0 \\
0 \\
0\end{array}$ & 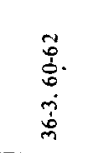 & 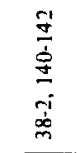 & $\begin{array}{l}\bar{a} \\
\dot{0} \\
\infty \\
\dot{1} \\
\dot{\nabla}\end{array}$ & 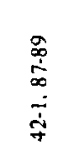 & 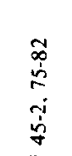 & 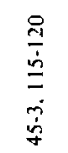 & 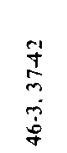 \\
\hline $\mathrm{SiO}_{2}$ & 45.89 & 51.82 & 50.05 & 50.62 & 49.61 & 48.18 & 51.00 & 49.46 \\
\hline $\mathrm{Al}_{2} \mathrm{O}_{3}$ & 34.50 & 30.30 & 30.56 & 31.46 & 31.31 & 33.11 & 30.66 & 31.46 \\
\hline $1+\mathrm{eO}^{*}$ & 0.41 & 0.81 & 0.59 & 0.70 & 0.74 & 0.62 & 0.64 & 0.80 \\
\hline $\mathrm{CaO}$ & 18.30 & 13.76 & 14.86 & 14.56 & 14.90 & 15.88 & 14.65 & 15.74 \\
\hline $\mathrm{N}_{\mathrm{i}_{2}} \mathrm{O}$ & 0.67 & 3.31 & 2.57 & 2.46 & 2.53 & 2.00 & 2.55 & 2.28 \\
\hline Total & 99.77 & 100.00 & 98.62 & 99.81 & 99.10 & 99.79 & 99.77 & 99.73 \\
\hline Si & 2.12 & 2.36 & 2.31 & 2.31 & 2.29 & 2.21 & 2.32 & 2.27 \\
\hline $\mathrm{Al}$ & 1.88 & 1.63 & 1.67 & 1.69 & 1.70 & 1.79 & 1.65 & 1.70 \\
\hline $\mathrm{Ie}$ & 0.02 & 0.03 & 0.02 & 0.03 & 0.03 & 0.02 & 0.02 & 0.03 \\
\hline $\mathrm{Ca}$ & 0.90 & 0.67 & 0.74 & 0.71 & 0.74 & 0.78 & 0.72 & 0.77 \\
\hline $\mathrm{Na}$ & 0.06 & 0.29 & 0.23 & 0.22 & 0.23 & 0.18 & 0.23 & 0.20 \\
\hline An & 93.75 & 69.69 & 76.16 & 76.56 & 76.48 & 81.41 & 76.06 & 79.23 \\
\hline $\mathrm{Ab}$ & 6.25 & 30.31 & 23.84 & 23.44 & 23.52 & 18.59 & 23.94 & 20.77 \\
\hline $\begin{array}{l}\text { Crystal } \\
\text { type }\end{array}$ & $\mathbf{p}$ & $g$ & $p$ & $m p$ & $m p$ & $\mathbf{p}$ & $\mathrm{mp}$ & $p$ \\
\hline
\end{tabular}

Note: $\mathrm{p}=$ phenocryst, $m p=$ microphenocryst, $g=$ groundmass. These abbreviations are used in wll the mineralogical tables.
TABLE 2

Representative Clinopyroxene Analyses (Hole 407), Normalized to Six Oxygens

\begin{tabular}{|c|c|c|c|c|c|}
\hline $\begin{array}{c}\text { Sample } \\
\text { (Interval in } \mathrm{cm} \text { ) }\end{array}$ & 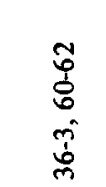 & 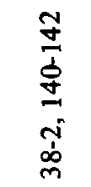 & $\begin{array}{l}\vec{a} \\
\dot{\infty} \\
\frac{1}{\dot{\sigma}}\end{array}$ & $\begin{array}{l}\infty \\
\infty \\
\infty \\
\frac{1}{\dot{1}} \\
\frac{i}{+}\end{array}$ & 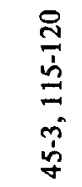 \\
\hline $\mathrm{SiO}_{2}$ & 53.49 & 50.47 & 52.25 & 52.35 & 50.55 \\
\hline $\mathrm{Al}_{2} \mathrm{O}_{3}$ & 1.68 & 3.48 & 1.95 & 1.78 & 4.24 \\
\hline $\mathrm{FeO}^{*}$ & 7.81 & 9.87 & 8.42 & 8.95 & 9.13 \\
\hline $\mathrm{MnO}$ & - & - & - & - & 0.19 \\
\hline $\mathrm{MgO}$ & 17.59 & 14.11 & 16.34 & 16.11 & 13.97 \\
\hline $\mathrm{CaO}$ & 18.82 & 20.27 & 19.71 & 19.71 & 20.24 \\
\hline $\mathrm{TiO}_{2}$ & 0.37 & 1.34 & 0.90 & 0.90 & 1.30 \\
\hline $\mathrm{Cr}_{2} \mathrm{O}_{3}$ & 0.24 & 0.25 & $\rightarrow$ & - & 0.33 \\
\hline Total & 100.00 & 99.82 & 99.56 & 99.80 & 99.95 \\
\hline $\mathrm{Si}$ & 1.96 & 1.89 & 1.94 & 1.94 & 1.88 \\
\hline $\mathrm{Al}^{\mathrm{IV}}$ & 0.04 & 0.11 & 0.06 & 0.06 & 0.12 \\
\hline $\mathrm{Al}^{\mathrm{VI}}$ & 0.03 & 0.04 & 0.03 & 0.02 & 0.07 \\
\hline $\mathrm{Fe}$ & 0.24 & 0.31 & 0.26 & 0.28 & 0.28 \\
\hline $\mathrm{Mn}$ & - & - & - & - & 0.01 \\
\hline $\mathbf{M g}$ & 0.96 & 0.79 & 0.90 & 0.89 & 0.77 \\
\hline $\mathrm{Ca}$ & 0.74 & 0.81 & 0.78 & 0.78 & 0.81 \\
\hline $\mathrm{Ti}$ & 0.01 & 0.04 & 0.02 & 0.02 & 0.04 \\
\hline $\mathrm{Cr}$ & 0.01 & 0.01 & - & - & 0.01 \\
\hline $\mathrm{Mg} / \mathrm{Mg}+\mathrm{Fe}^{2+} \%$ & 80.05 & 71.81 & 77.57 & 76.23 & 73.16 \\
\hline Wo & 38.10 & 42.59 & 40.23 & 40.14 & 43.25 \\
\hline En & 49.55 & 41.22 & 46.37 & 46.63 & 41.52 \\
\hline Fs & 12.35 & 16.19 & 13.40 & 14.23 & 15.23 \\
\hline $\begin{array}{l}\text { Crystal } \\
\text { type }\end{array}$ & $\mathrm{mp}$ & g & $\mathrm{mp}$ & $\mathrm{mp}$ & $\mathrm{mp}$ \\
\hline
\end{tabular}

to palagonite, but some fresh glass has been preserved (Plate 1, Figure 2). Microprobe analyses of these glasses and others from the Leg 49 holes are given in Table 3 . There are some significant chemical variations within this unit, e.g., $\mathrm{Ni}$ and $\mathrm{MgO}$ have an inverse correlation with $\mathrm{Fe}_{2} \mathrm{O}_{3} *$. $\mathrm{MgO}$ varies from about 9 to 6 wt. per cent and $\mathrm{Fe}_{2} \mathrm{O}_{3}$ from 11 to $15 \mathrm{wt}$. per cent, with a general increase towards the top of the unit, accompanied by a general increase in HYG-element concentrations. The fresh glass analyses from this unit (Table 3) correspond in composition to the low-MgO whole-rock analyses from this unit.

Microprobe analyses of the plagioclase and olivine phenocrysts in the glasses are given in Tables 1 and 4, respectively; they are relatively constant in composition (An81-76; Fos1-80). The olivine phenocrysts contain small, rare crystals of titaniferous magnesiochromites; microprobe analyses of these are included in Table 5.

All samples analyzed from this unit have relatively constant HYG-element ratios which are intermediate between the values for Units 2 and 3. At least part of the chemical variation within this unit may be explained by uneven distribution of olivine and plagioclase phenocrysts. Secondary alteration is probably also responsible for some of the variation.

A major-element variation diagram (Figure 4), an AFM diagram (Figure 5), and a biaxial HYG-element versus less 
TABLE 3

Basal tic Glass Analyses From Holes 407, 409, 410A, 411, 412, and 413

\begin{tabular}{|c|c|c|c|c|c|c|c|c|c|c|c|c|c|}
\hline $\begin{array}{c}\text { Sample } \\
\text { (Interval in } \mathrm{cm} \text { ) }\end{array}$ & 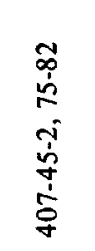 & 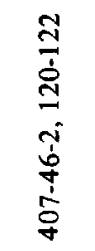 & \begin{tabular}{l}
\multirow{+}{+}{} \\
$\dot{m}$ \\
$\dot{m}$ \\
$\dot{0}$ \\
$\dot{+}$ \\
$\dot{+}$ \\
$\dot{q}$
\end{tabular} & 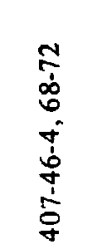 & $\begin{array}{l}\frac{ \pm}{2} \\
\dot{0} \\
0 \\
0 \\
0 \\
\frac{1}{d} \\
\dot{d}\end{array}$ & 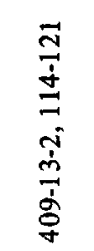 & $\frac{5}{\frac{5}{3}}$ & 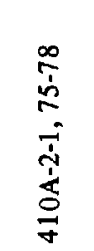 & 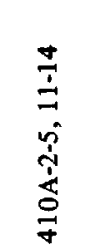 & 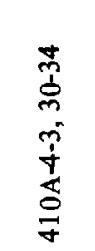 & $\begin{array}{l}\stackrel{m}{J} \\
\dot{J} \\
\stackrel{\sim}{J} \\
\dot{J}\end{array}$ & 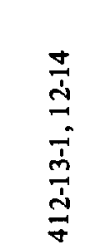 & 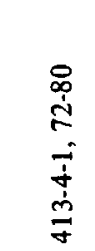 \\
\hline $\mathrm{SiO}_{2}$ & 49.04 & 49.44 & 49.46 & 49.63 & 50.43 & 49.99 & 52.13 & 51.80 & 51.70 & 50.69 & 49.29 & 51.15 & 48.92 \\
\hline $\mathrm{TiO}_{2}$ & 1.92 & 2.06 & 1.92 & 1.90 & 1.53 & 1.53 & 1.25 & 1.21 & 1.51 & 1.24 & 0.81 & 1.27 & 0.83 \\
\hline $\mathrm{Al}_{2} \mathrm{O}_{3}$ & 15.69 & 14.20 & 14.05 & 14.48 & 13.63 & 13.26 & 15.72 & 15.92 & 15.73 & 16.61 & 16.12 & 14.15 & 17.33 \\
\hline $\mathrm{FeO}^{*}$ & 11.93 & 12.45 & 12.61 & 12.11 & 12.19 & 12.25 & 8.18 & 8.31 & 8.17 & 7.97 & 9.32 & 11.24 & 10.01 \\
\hline $\mathrm{MnO}$ & 0.15 & 0.23 & 0.22 & 0.22 & 0.17 & 0.21 & - & 0.15 & - & 0.14 & 0.14 & 0.19 & 0.18 \\
\hline $\mathrm{MgO}$ & 6.23 & 6.69 & 6.52 & 6.61 & 6.24 & 6.10 & 6.90 & 6.95 & 7.05 & 7.12 & 9.33 & 7.49 & 9.44 \\
\hline $\mathrm{CaO}$ & 10.93 & 11.20 & 11.42 & 11.24 & 11.06 & 11.38 & 10.79 & 10.90 & 10.64 & 11.00 & 12.70 & 12.21 & 11.58 \\
\hline $\mathrm{Na}_{2} \mathrm{O}$ & 2.49 & 2.54 & 2.48 & 2.60 & 2.48 & 2.13 & 2.61 & 2.86 & 2.46 & 2.80 & 2.02 & 2.11 & 2.37 \\
\hline $\mathrm{K}_{2} \mathrm{O}$ & 0.19 & 0.21 & 0.25 & 0.21 & 0.13 & 0.18 & 0.45 & 0.63 & 0.51 & 0.85 & 0.12 & 0.10 & 0.10 \\
\hline $\mathrm{P}_{2} \mathrm{O}_{5}$ & 0.30 & 0.32 & 0.31 & 0.36 & 0.20 & 0.31 & 0.30 & 0.31 & 0.26 & 0.34 & - & - & - \\
\hline Total & 98.87 & 99.34 & 99.24 & 99.36 & 98.26 & 97.34 & 98.33 & 99.04 & 98.03 & 98.76 & 100.00 & 100.00 & 100.00 \\
\hline
\end{tabular}

TABLE 4

Olivine Analyses (Hole 407), Normalized to Four Oxygens

\begin{tabular}{|c|c|c|c|}
\hline $\begin{array}{c}\text { Sample } \\
\text { (Interval in } \mathrm{cm} \text { ) }\end{array}$ & 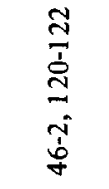 & $\begin{array}{l}n \\
d \\
m \\
m \\
d \\
d\end{array}$ & $\begin{array}{l}n \\
m \\
\dot{n} \\
0\end{array}$ \\
\hline $\mathrm{SiO}_{2}$ & 39.11 & 38.70 & 38.73 \\
\hline FeO* & 18.18 & 17.57 & 17.92 \\
\hline $\mathrm{MnO}$ & 0.20 & - & 0.34 \\
\hline $\mathrm{MgO}$ & 41.79 & 41.71 & 41.10 \\
\hline $\mathrm{CaO}$ & 0.28 & 0.41 & 0.24 \\
\hline $\mathrm{CoO}$ & 0.49 & 0.39 & - \\
\hline $\mathrm{NiO}$ & - & - & 0.23 \\
\hline Total & 100.05 & 98.79 & 98.56 \\
\hline $\mathbf{S i}$ & 1.00 & 1.00 & 1.00 \\
\hline $\mathrm{Fe}$ & 0.39 & 0.38 & 0.39 \\
\hline Mn & 0.00 & - & 0.01 \\
\hline $\mathbf{M g}$ & 1.59 & 1.60 & 1.59 \\
\hline $\mathrm{Ca}$ & 0.01 & 0.01 & 0.01 \\
\hline Co & 0.01 & 0.01 & - \\
\hline $\mathrm{Ni}$ & - & - & 0.00 \\
\hline $\mathrm{Mg} / \mathrm{Mg}+\mathrm{Fe}^{2+} \%$ & 80.38 & 80.88 & 80.35 \\
\hline $\begin{array}{l}\text { Crystal } \\
\text { type }\end{array}$ & $\mathrm{p}$ & p & $\mathbf{p}$ \\
\hline
\end{tabular}

incompatible trace-element diagram (Figure 6) for all the samples analyzed from this hole illustrate that there is considerable chemical variation within this 154.5-meter vertical section. Such variation places severe limitations on the value of chemical gradients established from analyses of one or two dredged samples from a particular latitude. An analogy can be drawn between vertical variation in Hole
TABLE 5

Titaniferous Magnesiochromites From Holes 407 and 410A, Normalized to 32 Oxygens

$\left(\mathrm{Fe}^{2+}\right.$ and $\mathrm{Fe}^{3+}$ estimated from stoichiometry)

\begin{tabular}{|c|c|c|c|c|}
\hline $\begin{array}{c}\text { Sample } \\
\text { (Interval in } \mathrm{cm} \text { ) }\end{array}$ & 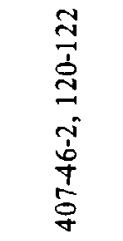 & 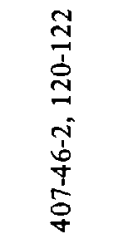 & 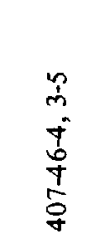 & 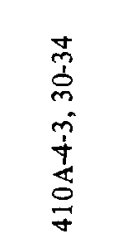 \\
\hline $\mathrm{SiO}_{2}$ & 0.21 & 0.26 & 0.46 & 0.26 \\
\hline $\mathrm{TiO}_{2}$ & 2.50 & 2.77 & 2.18 & 0.82 \\
\hline $\mathrm{Al}_{2} \mathrm{O}_{3}$ & 17.60 & 16.60 & 17.38 & 25.67 \\
\hline $\mathrm{Cr}_{2} \mathrm{O}_{3}$ & 32.02 & 32.94 & 32.29 & 35.21 \\
\hline $\mathrm{Fe}_{2} \mathrm{O}_{3}$ & 18.94 & 19.69 & 17.56 & 9.83 \\
\hline $\mathrm{FeO}$ & 18.33 & 17.63 & 17.99 & 12.91 \\
\hline $\mathrm{MnO}$ & 0.55 & 0.49 & 0.40 & 0.40 \\
\hline $\mathrm{MgO}$ & 10.22 & 9.87 & 10.20 & 14.70 \\
\hline $\mathrm{CoO}$ & 0.52 & 0.26 & 0.45 & 0.50 \\
\hline Total & 100.89 & 100.61 & 99.01 & 100.30 \\
\hline $\mathrm{Si}$ & 0.053 & 0.066 & 0.121 & 0.062 \\
\hline $\mathrm{Ti}$ & 0.467 & 0.530 & 0.422 & 0.146 \\
\hline $\mathrm{Al}$ & 5.262 & 4.973 & 5.871 & 7.202 \\
\hline $\mathrm{Cr}$ & 6.422 & 6.625 & 6.567 & 6.630 \\
\hline $\mathrm{Fe}^{3+}$ & 3.616 & 3.767 & 3.399 & 1.958 \\
\hline $\mathrm{Fe}^{2+}$ & 3.888 & 3.754 & 3.869 & 2.312 \\
\hline $\mathrm{Mn}$ & 0.119 & 0.105 & 0.087 & 0.080 \\
\hline $\mathbf{M g}$ & 3.856 & 3.741 & 3.910 & 5.222 \\
\hline $\mathrm{Co}$ & 0.105 & 0.052 & 0.091 & 0.096 \\
\hline $\mathrm{Mg} / \mathrm{Mg}+\mathrm{Fe}^{2+}$ & 0.498 & 0.499 & 0.503 & 0.693 \\
\hline $\mathrm{Cr} / \mathrm{Cr}_{\mathrm{r}}+\mathrm{Al}$ & 0.550 & 0.571 & 0.555 & 0.479 \\
\hline $\mathrm{Fe}^{3+} / \mathrm{Fe}^{3+}+\mathrm{Cr}+\mathrm{Al}$ & 0.236 & 0.245 & 0.223 & 0.124 \\
\hline $\begin{array}{l}\mathrm{Mg} / \mathrm{Mg}+\mathrm{Fe}^{2+} \\
\text { of host } \mathrm{Ol}\end{array}$ & 0.804 & 0.804 & 0.803 & 0.861 \\
\hline
\end{tabular}




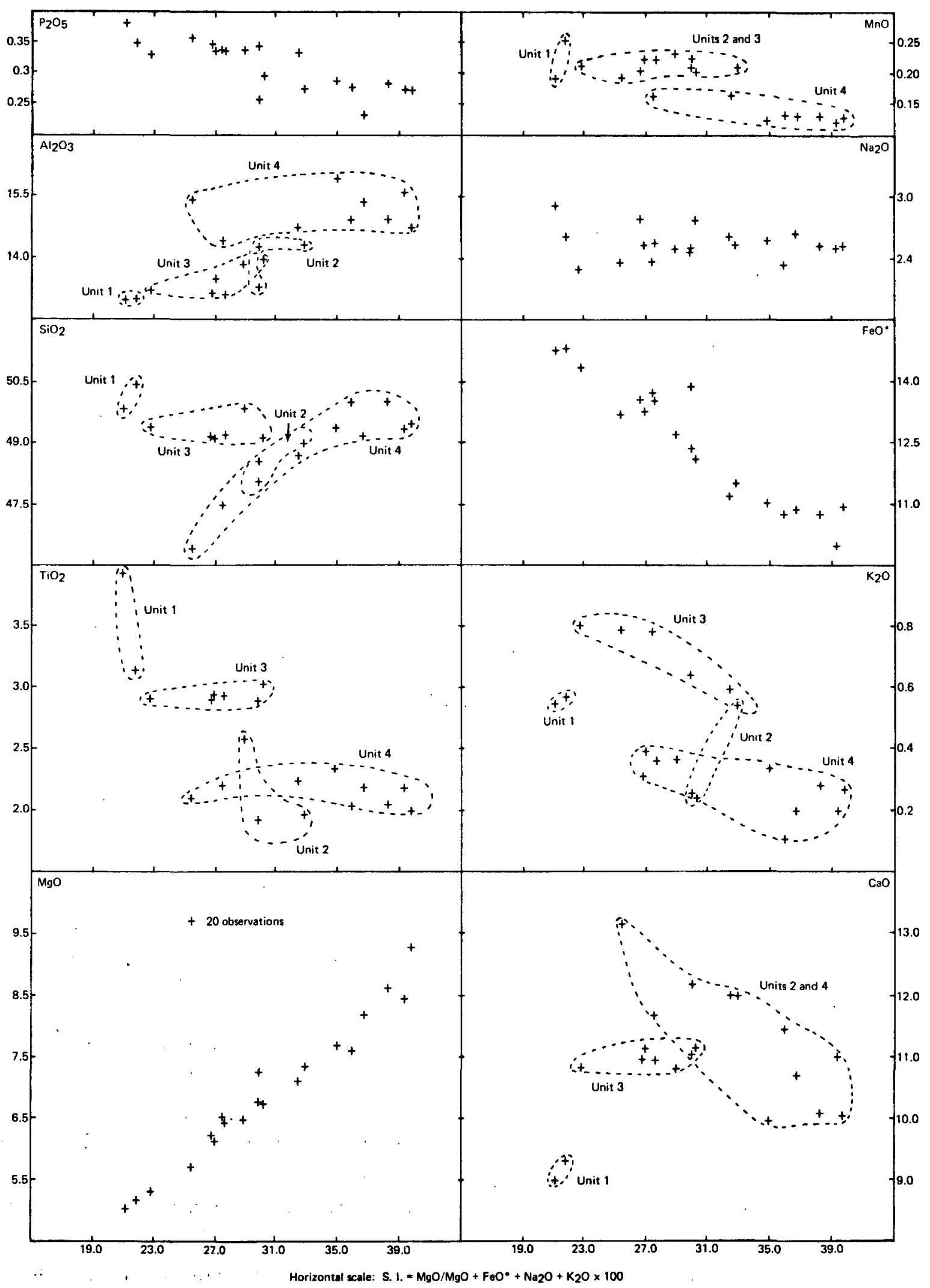

Figure 4. Variation diagram for major elements in Hole 407, using Solidification Index (S.I. $=\mathrm{MgO} / \mathrm{MgO}+$ $\mathrm{FeO}^{*}+\mathrm{Na}_{2} \mathrm{O}+\mathrm{K}_{2} \mathrm{O}$ ). The geochemical units shown in Figure 3 have been distinguished. 


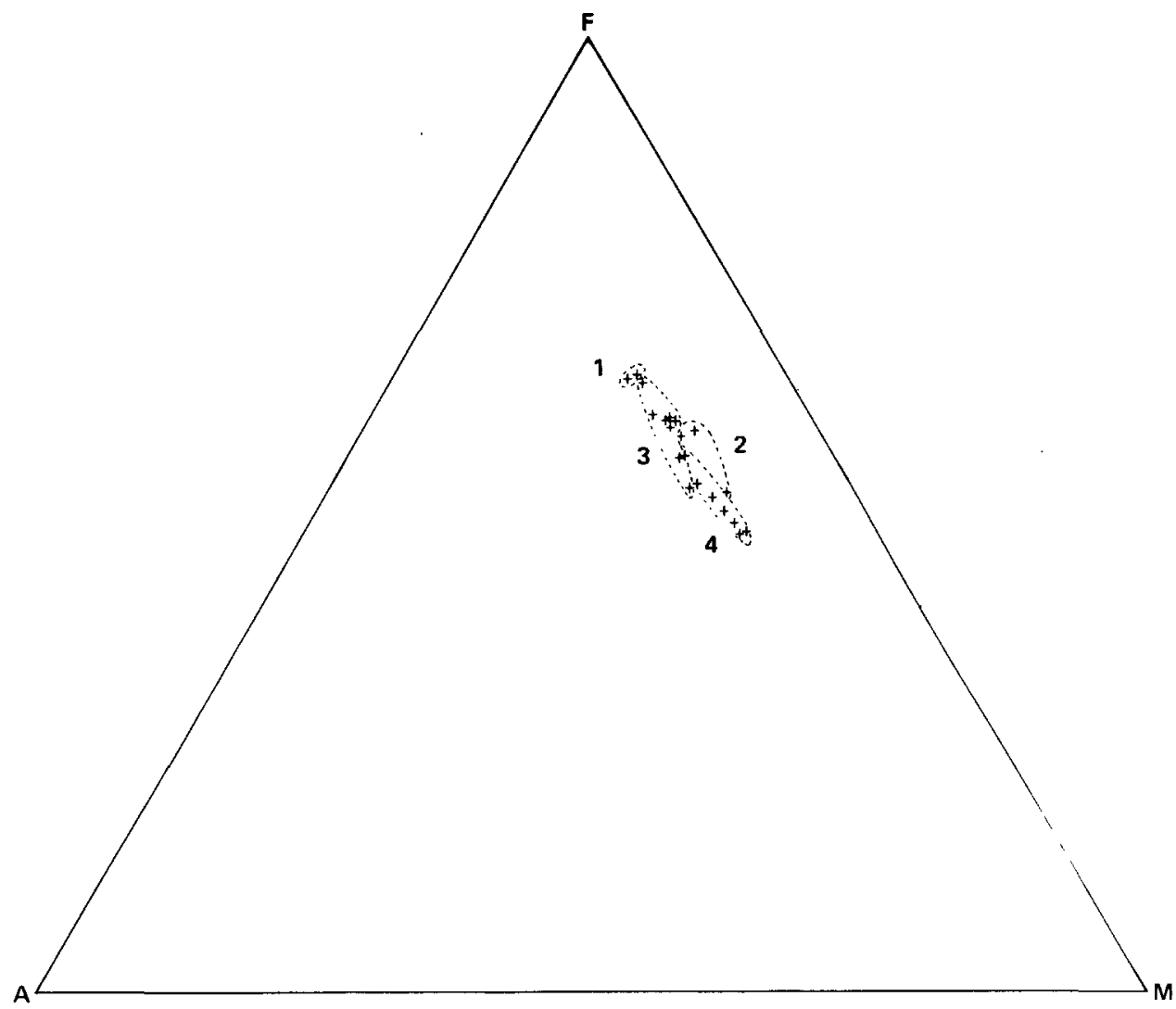

Figure 5. AFM diagram for Hole 407. The four geochemical units have been distinguished (see Figure 3).

407 and vertical variation at a given locality in the dissected Tertiary lava pile of Eastern Iceland (Figure 7). It is significant that the range of $(\mathrm{Ce} / \mathrm{Yb})_{\mathrm{N}}$ ratio in Hole 407 is identical to that observed in Eastern Iceland (Wood, in press $)$. Basalts with $(\mathrm{Ce} / \mathrm{Yb})_{\mathrm{N}}$ ratios similar to the Hole 407 basalts have also been reported for Holes 336,345 , and 350 of Leg 38 (Figure 1) (Schilling, 1977).

Figure 6 shows that the basalts of Units 1 and 3 have similar HYG-element ratios. A least-squares mixing computer program (Wright and Doherty, 1970) has been used to demonstrate that the ferrobasalt of Unit 1 may be derived from the basalt of Unit 3 by crystal fractionation of a realistic mineral assemblage (Table 6). The fractionating mineral proportions are comparable to those calculated for similar "liquid" intervals in the Eastern Iceland series (Wood, in press), with approximately equal proportions of augite and plagioclase involved in the solutions. This solution is compatible with the transition metal concentrations in the two units. The similarity of Co concentrations in the two units (about 50 ppm) precludes the fractionation of large proportions of olivine (the olivine/liquid partition coefficient for Co $\mathrm{K}_{\mathrm{Co}}^{\mathrm{O} / 1}-$ is close to 3 [Bougault and Hekinian, 1974]). The concentrations of $\mathrm{Cr}$ and $\mathrm{Ni}$ in the basalts place constraints on the proportions of olivine and augite in the fractionating assemblage ( $\mathrm{K}_{\mathrm{Cr}}^{\mathrm{aug} / 1}$ and $\mathrm{K}_{\mathrm{Ni}}^{\mathrm{ol} / 1}$ are similar, i.e., both about 12 [Bougault and Hekinian, 1974, Fig. 3]). Cr decreases from Unit 3 to Unit 1 by a factor of 4 , whereas Ni only decreases by a factor of 2 , suggesting that augite fractionation is greater than olivine fractionation.

The similar compositions of Units 1 and 3 of Hole 407 and the most abundant basalt type found in Eastern Iceland make it possible to estimate the composition of the more magnesian liquids from which these relatively evolved basalts $(\mathrm{MgO}=5$ and $6.5 \mathrm{wt} . \%)$ have been derived. Table 7 presents a least-squares mixing solution for the most primitive basalt of Unit 3 (viz., Sample 407-42-1, 87-89 $\mathrm{cm}$ ) and the most primitive Eastern Iceland basalt with the same $(\mathrm{Ce} / \mathrm{Yb})_{\mathrm{N}}$ and other HYG-element ratios (sample V 10 , Wood, in press). The realistic calculated mineral assemblage ( $\mathrm{Pl}<\mathrm{Ol}<$ Aug; cf. Tables 1, 2, and 4 for phenocryst compositions) suggests that the crystal fractionation processes responsible for production of Units 1 and 3 of Hole 407 were similar to those operating in Eastern Iceland. The predominance of plagioclase over olivine in the fractionating assemblage explains the tholeiitic $\mathrm{Fe}$ enrichment trend shown by the Hole 407 basalts (Figure 5).

\section{Hole 408}

This hole is on a topographic high within magnetic anomaly 6 (about $20 \mathrm{~m} . \mathrm{y}$. ), corresponding in age approximately to the oldest subaerially erupted lavas in Iceland, and hence to enhanced activity of the supposed mantle plume. The hole was drilled in a water depth of 1624 meters, and penetrated 23.3 meters into basaltic basement. The relatively short basement section recovered from this 


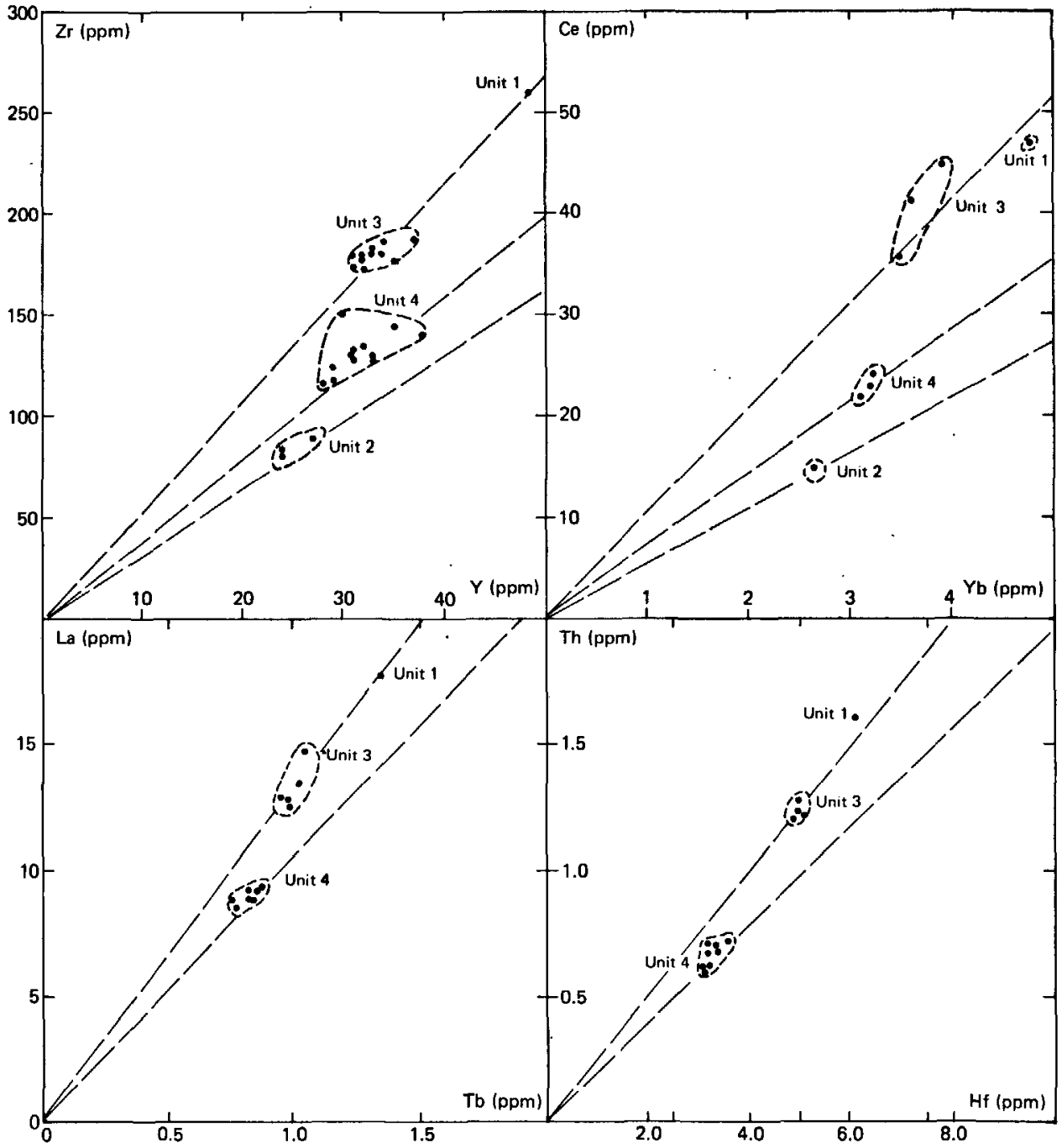

Figure 6. HYG-element plots for Hole 407. Zr from Tarney et al. (this volume). Ce and $Y b$ data provided by Wood. Ca, Tb, Th, and $\mathrm{H}$ f are from Treuil and Joron (see appendices). All data show that magma types of Units 2, 3, and 4 are different, whereas magma type of Unit 1 is similar to Unit 3, but more fractionated.

hole consists of aphyric to sparsely plagioclase and olivine phyric basalt, petrographically similar to Units 3 and 4 of Hole 407. The section is more altered than others recovered on Leg 49; abundant calcite, smectite, and celadonite (in that order) occur in veins and vesicles. Olivine is preserved only in some of the chilled margins, and is usually pseudomorphed by secondary minerals in the holocrystalline sections of the cores. Two lithostratigraphic units have been distinguished on the bases of petrographic and chemical data (Figure 8), and the boundary corresponds to a change in magnetic inclination.

Unit 1: This upper unit consists of at least three flows and one indurated hyaloclastite at the top. The hyaloclastite and the upper flow are aphyric, with rare plagioclase microphenocrysts, whereas the lower flows are sparsely plagioclase and olivine phyric and contain more calcic plagioclase (bytownite) than the upper flows. Figure 8 indicates that the upper flows of Unit 1 show greater chemical variation and generally have lower $\mathrm{MgO}$ and higher $\mathrm{Fe}_{2} \mathrm{O}_{3}$ * and $\mathrm{HYG}$-element concentrations than the lower flows. At first glance, the variation in the upper part of this unit appears to be the result of crystal fractionation, but the very high $\mathrm{CaO}$ and low $\mathrm{SiO}_{2}$ of these flows, revealed by the major-element variation diagram (Figure 9), as well as higher absolute abundances of HYG elements in some of the more $\mathrm{Mg}$-rich basalts, suggest that alteration is largely responsible for this variation. The modal abundance of calcite and other secondary phases in these flows confirms this.

Unit 2: This unit consists of either a succession of basaltic pillows or very thin flows separated by glassy margins. The glass is almost totally altered. The basalt is aphyric with a variolitic texture and generally has higher concentrations of HYG elements Ti, P, Y and of heavy REE than Unit 1 , but also higher $\mathrm{MgO}, \mathrm{Ni}, \mathrm{Co}$ and lower $\mathrm{CaO}$ and $\mathrm{K}_{2} \mathrm{O}$ than Unit 1 (Figures 8 and 9). This chemical variation between Units 1 and 2 is tentatively explained by alteration, especially because of the variable distribution of 


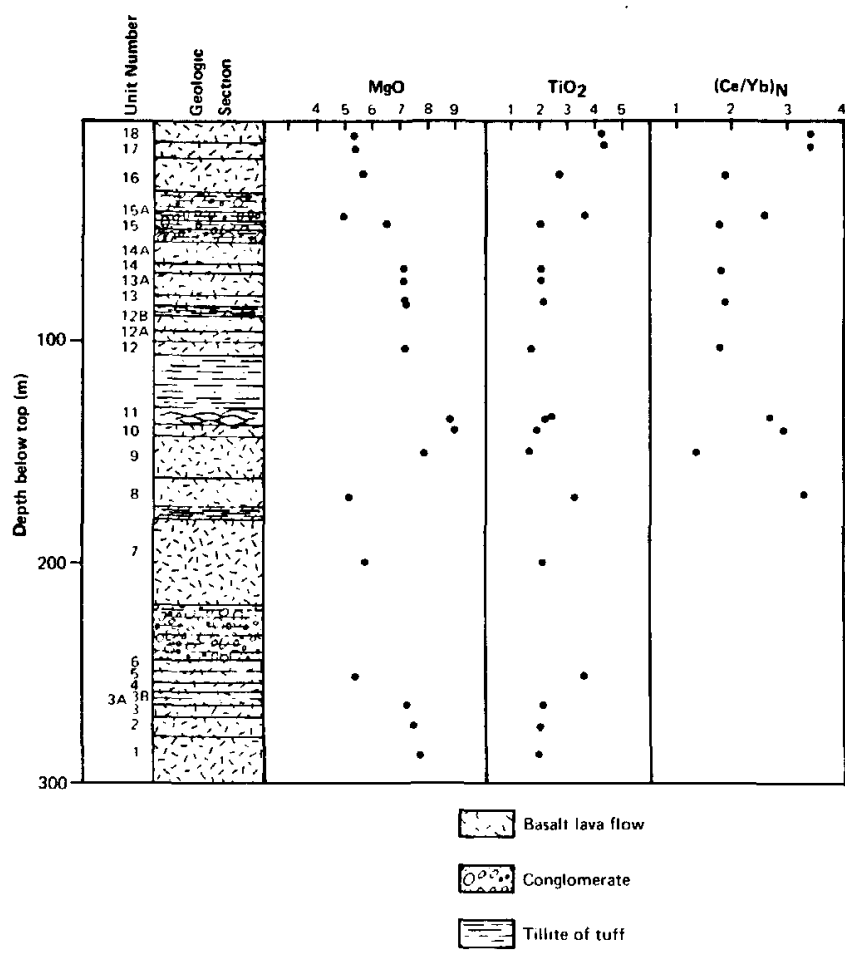

Figure 7. Geological profile in eastern Iceland (geomagnetic traverse Profile $V$ of Watkins and Walker (1977). Compare geological profile and geochemical variations with Hole 407 profile of Figure 3. Geochemical data are from Wood (unpublished).

TABLE 6

Least-Squares Crystal Fractionation Solution for Units 1 and 3 of Hole 407

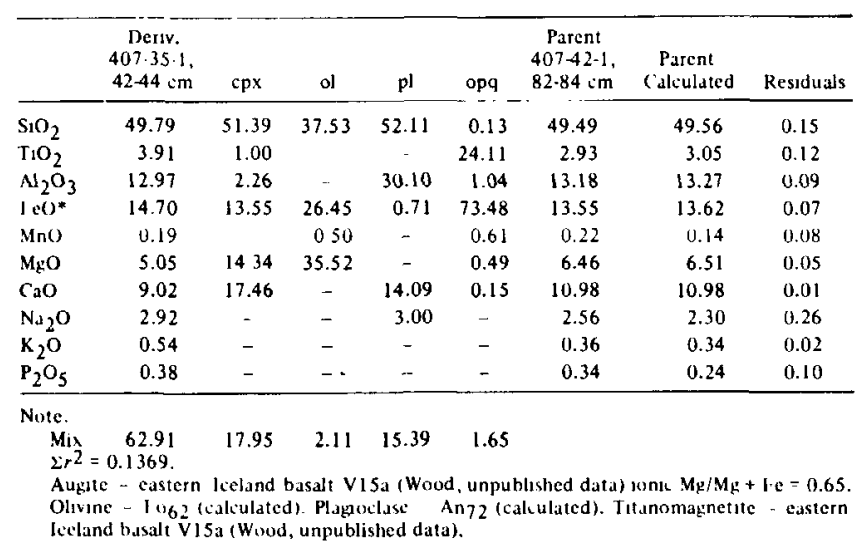

calcite: Unit 2 is more homogeneous and less altered than Unit 1. Both units have the same $\mathrm{Ce} / \mathrm{Yb}, \mathrm{Zr} / \mathrm{Y}$, etc., ratios (Figure 10). More detailed plots of Th versus other less incompatible elements, e.g., $\mathrm{Hf}$ and $\mathrm{Tb}$ (Figure 11) reveal that there are differences between the two units. However, it is not clear whether these small differences or the differences in $\mathrm{K}_{2} \mathrm{O}$, $\mathrm{TiO}_{2}$, and $\mathrm{P}_{2} \mathrm{O}_{5}$ between the two units (Figure 9) are results of magmatic processes (i.e., crystal fractionation or different parental liquids) or hydrothermal processes (i.e., elemental mobility or dilution of element concentrations by high modal abundances of secondary minerals).
TABLE 7

Least-Squares Crystal Fractionation Solution for Eastern Iceland Parental Basalt V10 (Wood, in press) and Unit 3 of Hole 407

\begin{tabular}{|c|c|c|c|c|c|c|c|}
\hline & $\begin{array}{c}\text { Deriv. } \\
407-42-1 \text {, } \\
82-84 \mathrm{~cm}\end{array}$ & cpx & ol & pl & $\begin{array}{l}\text { Parent } \\
\text { E. Iceland } \\
\text { V10 }\end{array}$ & $\begin{array}{c}\text { Parent } \\
\text { Calculated }\end{array}$ & Residuals \\
\hline $\mathrm{SiO}_{2}$ & 49.41 & 53.54 & 39.20 & 48.93 & 48.19 & 48.46 & 0.27 \\
\hline $\mathrm{IiO}_{2}$ & 2.93 & 0.59 & - & - & 1.91 & 1.92 & 0.01 \\
\hline $\mathrm{Al}_{2} \mathrm{O}_{3}$ & 13.18 & 0.92 & - & 32.42 & 15.42 & 15.48 & 0.06 \\
\hline $\mathrm{FeO}^{*}$ & 13.55 & 10.70 & 18.22 & 0.57 & 11.13 & 11.12 & 0.01 \\
\hline $\mathrm{MnO}$ & 0.22 & 0.20 & 0.40 & - & 0.18 & 0.19 & 0.01 \\
\hline $\mathrm{MgO}$ & 6.46 & 17.73 & 41.89 & - & 9.06 & 9.08 & 0.02 \\
\hline $\mathrm{CaO}$ & 10.98 & 16.32 & 0.28 & 15.96 & 11.39 & 11.20 & 0.19 \\
\hline $\mathrm{Na}_{2} \mathrm{O}$ & 2.56 & - & - & 2.12 & 2.31 & 2.10 & 0.20 \\
\hline $\mathrm{K}_{2} \mathrm{O}$ & 0.36 & - & - & - & 0.23 & 0.23 & 0.00 \\
\hline $\mathrm{P}_{2} \mathrm{O}_{5}$ & 0.34 & - & - & - & 0.18 & 0.22 & 0.03 \\
\hline $\begin{array}{l}\text { Note: } \\
\text { Mix } \\
\Sigma r^{2}\end{array}$ & $\begin{array}{l}64.53 \\
.1563 .\end{array}$ & 4.09 & 9.99 & 21.39. & & & \\
\hline
\end{tabular}

\section{Hole 409}

This hole is close to the crest of the Reykjanes Ridge, within magnetic anomaly $2^{\prime}$, close to the boundary between the Matuyama and Gauss magnetic epochs (about 2.3 m.y.). According to the mantle-plume interpretation of the Reykjanes Ridge bathymetric anomaly (Vogt, 1972), basalts erupted in this area should be influenced by overspill from the Iceland mantle source. The position of the site close to the crest of the ridge has provided material with which to assess the geochemical gradient proposed from dredged samples (Schilling, 1973) in terms of variation at one location along the trend. Figure 12 clearly shows that the variation of the elements and ratios used by Schilling (1973) to define the geochemical gradient is very large in this hole.

Hole 409 penetrated 240 meters into basaltic basement (the deepest single bit hole to date), although it was also drilled in the shallowest water $(832 \mathrm{~m})$ for a DSDP site. Some 58 basaltic flows were penetrated, according to interpretations made on board (Site Report chapter. Site 409), with an average thickness of 3 to 4 meters. All the flows consist of fine-grained, aphyric to sparsely plagioclase phyric (and more rarely with olivine microphenocrysts) basalt, generally fresh and highly vesicular. Vesicularity is variable, reaching 30 per cent in some flows (Duffield, this volume), and was undoubtedly an important contributing factor to the deep penetration of the hole. Four main lithostratigraphic units have been distinguished, using the petrographic and geochemical data (Figure 13).

Unit 1: This unit consists of 10 flows with variable petrography, including aphyric, plagioclase phyric, and plagioclase, olivine, and augite phyric types. The variability is also reflected in the chemistry. The glassy contact between sediment and the uppermost porphyritic basalt flow (Plate 1, Figure 4) has been analyzed by microprobe (Table 3 ). The phenocryst compositions in this glass (plagioclase Ango-71, olivine Fos1, augite with ionic $\mathrm{Mg} / \mathrm{Mg}+\mathrm{Fe}=80$ ) (Tables 8,9 , and 10) cannot be taken as representative of the unit as a whole, because wider variations were noted by microscopic determinations. A clear inverse correlation 


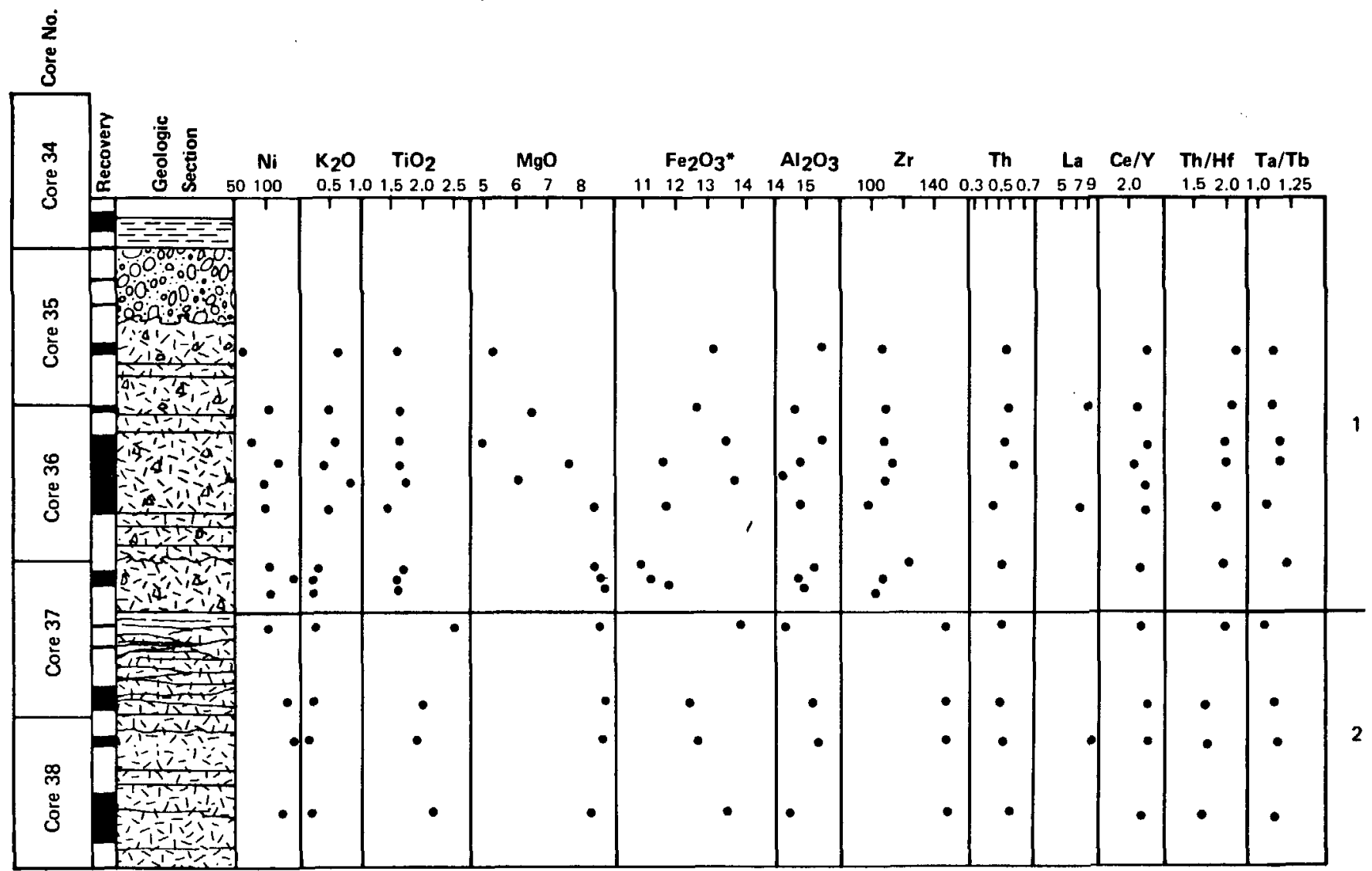

Figure 8. Detailed lithostratigraphic section of Hole 408. For source of analytical data see Figure 3.

exists between $\mathrm{MgO}$ and $\mathrm{Fe}_{2} \mathrm{O}_{3} *$ (Figure 13), and one sample $(409-10-2,22-24 \mathrm{~cm})$ reaches a ferrobasalt composition ( $\mathrm{MgO} 4 \% ; \mathrm{Fe}_{2} \mathrm{O}_{3} 19.6 \%$ ). The correlation between major- and trace-element variation within this unit, and the constant values of the HYG-element ratios (Figure 13), suggest that all the flows may be related by crystal fractionation.

Unit 2: This unit consists of seven flows mainly of sparsely plagioclase and olivine phyric basalt with rare pyroxene phenocrysts (Tables 8,9 , and 10). In the upper part of the unit, one flow is aphyric and another is olivine phyric. Chemical analyses confirm the relatively constant composition of this unit (Figure 13), and indicate that it is similar to the most basic flows of Unit 1. The similar HYG-element ratios of Units 1 and 2 (Figure 13) suggest that they may be linked by crystal fractionation. Table 11 gives a least-squares solution for a crystal fractionation calculation involving a basic composition from Unit 2 and a more evolved composition from Unit 1 .

Unit 3: This unit consists of some 40 flows, and includes almost all the remaining cores recovered. The uppermost flows (above Core 19) are petrographically homogeneous aphyric olivine basalt with a sub-ophitic texture. These flows are also chemically homogeneous. There is more petrographic and chemical variation between Cores 19 and 27 , including aphyric, plagioclase sparsely phyric, plagioclase and olivine sparsely phyric, and plagioclase, olivine, and augite sparsely phyric types. The lowest part of this unit consists of aphyric basalt of constant petrography.

Unit 4: This unit cannot be distinguished petrographically from Unit 3, but one sample from Core 32 has major- and trace-element chemistry intermediate between that of Unit 2 and that of Unit 3.

A major-element variation diagram for Hole 409 (Figure 14) reveals that Unit 3 forms a group distinct from Units 1 and 2. This is particularly evident for $\mathrm{SiO}_{2}, \mathrm{TiO}_{2}, \mathrm{P}_{2} \mathrm{O}_{5}$, $\mathrm{K}_{2} \mathrm{O}, \mathrm{FeO}^{*}$, and $\mathrm{MgO}$. $\mathrm{CaO}$ and $\mathrm{SiO}_{2}$ contents are more variable in Unit 3, owing to the presence of calcite in some samples. The intermediate nature of Unit 4 is apparent from Figure 14. The two groups (Unit 3; Units 1 and 2) show parallel but distinct major-element variation, and are difficult to relate by crystal fractionation.

Figure 15 shows that Unit 3 can also be clearly distinguished from Units 1 and 2 by HYG-element concentrations and ratios. Unit 4 also has HYG-element ratios intermediate with respect to the other units (Figures 13 and 15). Transition-element concentrations also demonstrate that Unit 3 cannot be derived from either Unit 1 or Unit 2 by crystal fractionation. As crystallization proceeds, HYG-element concentrations increase in the liquid, and compatible trace-element concentrations (e.g., those of $\mathrm{Cr}$ and $\mathrm{Ni}$ ) decrease. This is not so for the units of Hole 409: Unit 3 has higher HYG-element concentrations than Units 1 and 2, but also has higher $\mathrm{Ni}$ concentrations. 


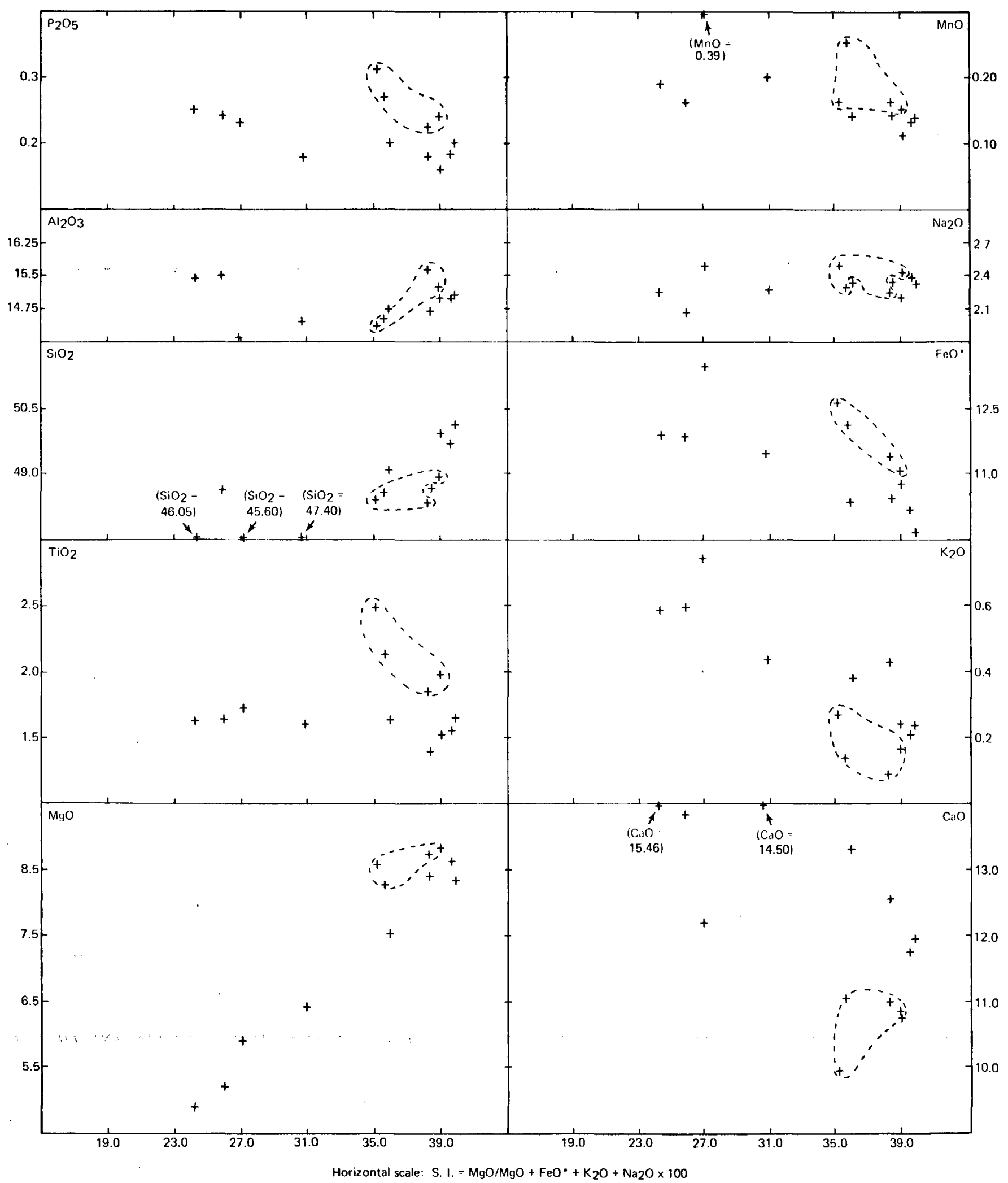

Figure 9. Variation diagram for major elements in Hole 408. S.I. $=\mathrm{MgO} / \mathrm{MgO}+\mathrm{FeO}^{*}+\mathrm{Na}_{2} \mathrm{O}+\mathrm{K}_{2} \mathrm{O}$. Unit 2 (see Figure 8) has been distinguished by dashed contours. 


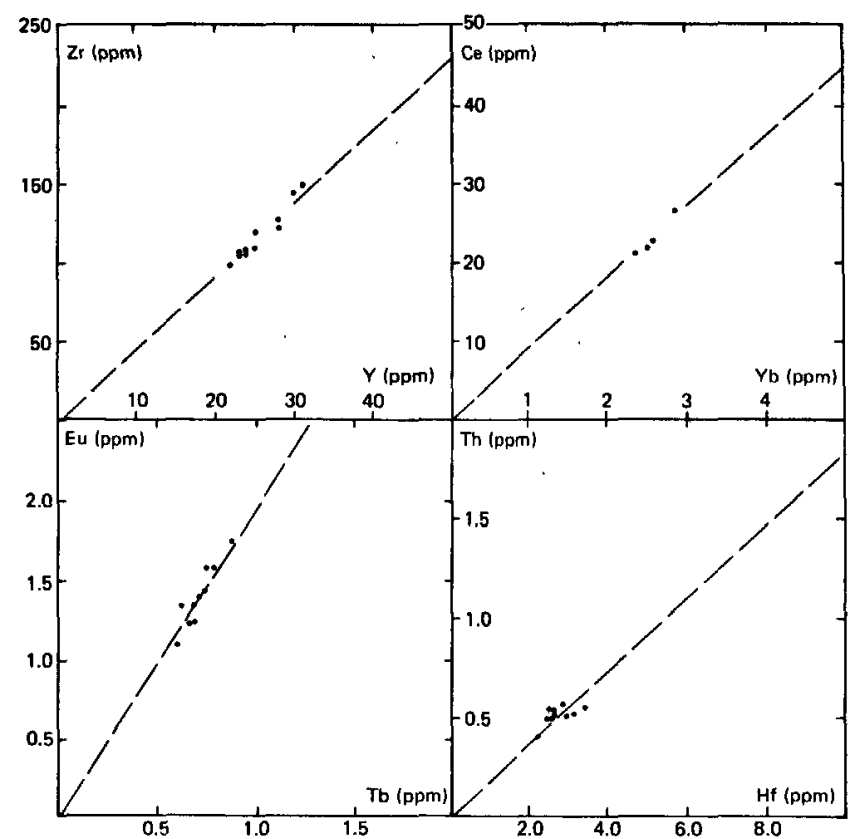

Figure 10. HYG-element plots for Hole 408. See Figure 6 for source of data. Dispersion of points along a line passing through the origin shows the extent of crystal fractionation.

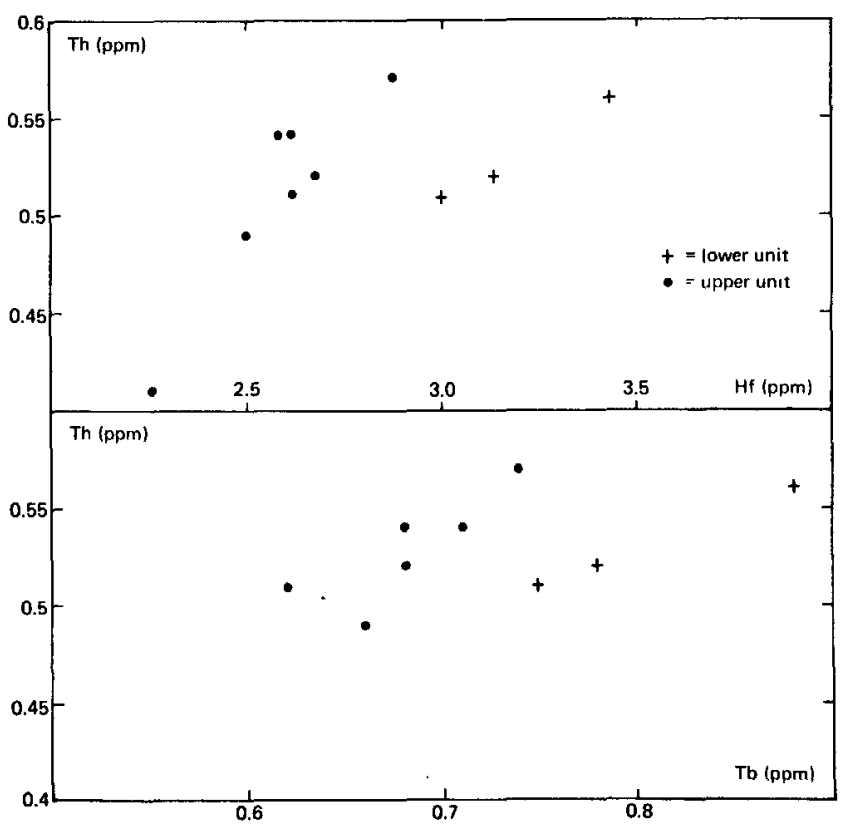

Figure 11. Detailed $\mathrm{Tb}$ and $\mathrm{Hf}$ versus $\mathrm{Th}$ diagrams for Hole 408. Data from Treuil and Joron. Two trends are distinguished with slightly different $H Y G$ ratios. Dots: Unit 1; crosses: Unit 2.

\section{VARIATION ALONG THE LEG 49 TRANSECT AT $63^{\circ} \mathrm{N}$}

The data presented above have enabled us to make majorand trace-element comparisons between Sites 407, 408, and 409. Figure 16 shows that the basalts from the three holes form distinct groups; those from Hole 407 (oldest) are generally richer in $\mathrm{TiO}_{2}$ and alkali. A characteristic of these holes is the wide variation in $\mathrm{MgO}$ (about 10 to $4 \mathrm{wt} . \%$ ) and also of $\mathrm{MgO} / \mathrm{MgO}+\mathrm{FeO}^{*}$ (about 0.5 to 0.25 ), reflecting the tholeiitic trend toward Fe enrichment (Figure 17). Much of the variation within each hole is the result of closed-system crystal fractionation, but as pointed out above, the variation between the holes and a significant amount of the variation within Holes 407 and 409 cannot be explained by this process.

Biaxial HYG-element plots and Masuda-Coryell REE diagrams (Figures 18 and 19), showing the range of HYG-element ratios for the three holes, distinguish the range of variation which cannot be attributed to closed-system crystal fractionation processes. Basalts with the lowest HYG-element ratios occur in the youngest hole, those with the highest ratios in the oldest hole. Comparison of Figures 16, 17, 18, and 19 suggests that the trace-element variation is consistent with the major-element variation in these three holes. Figure 20 confirms this correlation between major elements and HYG-element ratios for 19 representative samples from the three holes. This diagram also includes 18 aphyric, $\mathrm{Mg}$-rich basalts from Eastern Iceland (Wood, in press) and six Mg-rich basalts erupted in the active zones of Iceland and surrounding MAR (analyses of these six basalts have been included in Table 12 for comparison with the $63^{\circ} \mathrm{N}$ samples) which show similar compositional ranges. It is apparent that the basalts from Holes 407, 408, and 409 lie within the range of basalts erupted in Iceland, which vary from tholeiites with low $(\mathrm{Ce} / \mathrm{Yb})_{N}$ (and other such ratios) to alkali basalts with high $(\mathrm{Ce} / \mathrm{Yb})_{\mathrm{N}}$.

A more detailed plot of a HYG element (Th) versus a less incompatible trace element ( $\mathrm{Tb}$ ) (Figure 21 ) readily distinguishes the basalts related by closed-system crystal fractionation (i.e., straight line passing through the origin) and the relationship between the parent magmas. The compositions of the parent magmas are approximated by those analyses with the lowest concentrations of HYG elements for a particular $\mathrm{Th} / \mathrm{Tb}$ ratio. The non-porphyritic nature of most of the basalts taken from these three holes makes such approximations realistic, although the relatively low $\mathrm{MgO}(<8 \%)$ and $\mathrm{FeO}^{*} /\left(\mathrm{FeO}^{*}+\mathrm{MgO}\right)(>0.6)$ of the most primitive members of some of the groups suggests that they have undergone some crystal fractionation with respect to the primary liquids. Figure 21 distinguishes at least two parental liquid compositions from both Holes 407 and 409 , with 408 in an intermediate position between them. Figures 18 and 21 show that the parental liquids lie approximately on a straight line, and Figure 22 confirms that this is so for several element pairs. It has been shown that a linear variation of parental liquids not passing through the origin on plots of a HYG element versus a less incompatible element is not consistent with equilibrium partial melting of a homogeneous source, which would produce curved trends on such diagrams (Treuil and Varet, 1973).

Sr-isotope data (Table 13) for 14 representative samples from Holes 407, 408, and 409 (using a leaching technique to eliminate the effects of sea-water contamination) confirm that the different magma types cannot be derived from a homogeneous mantle source by equilibrium partial melting. 

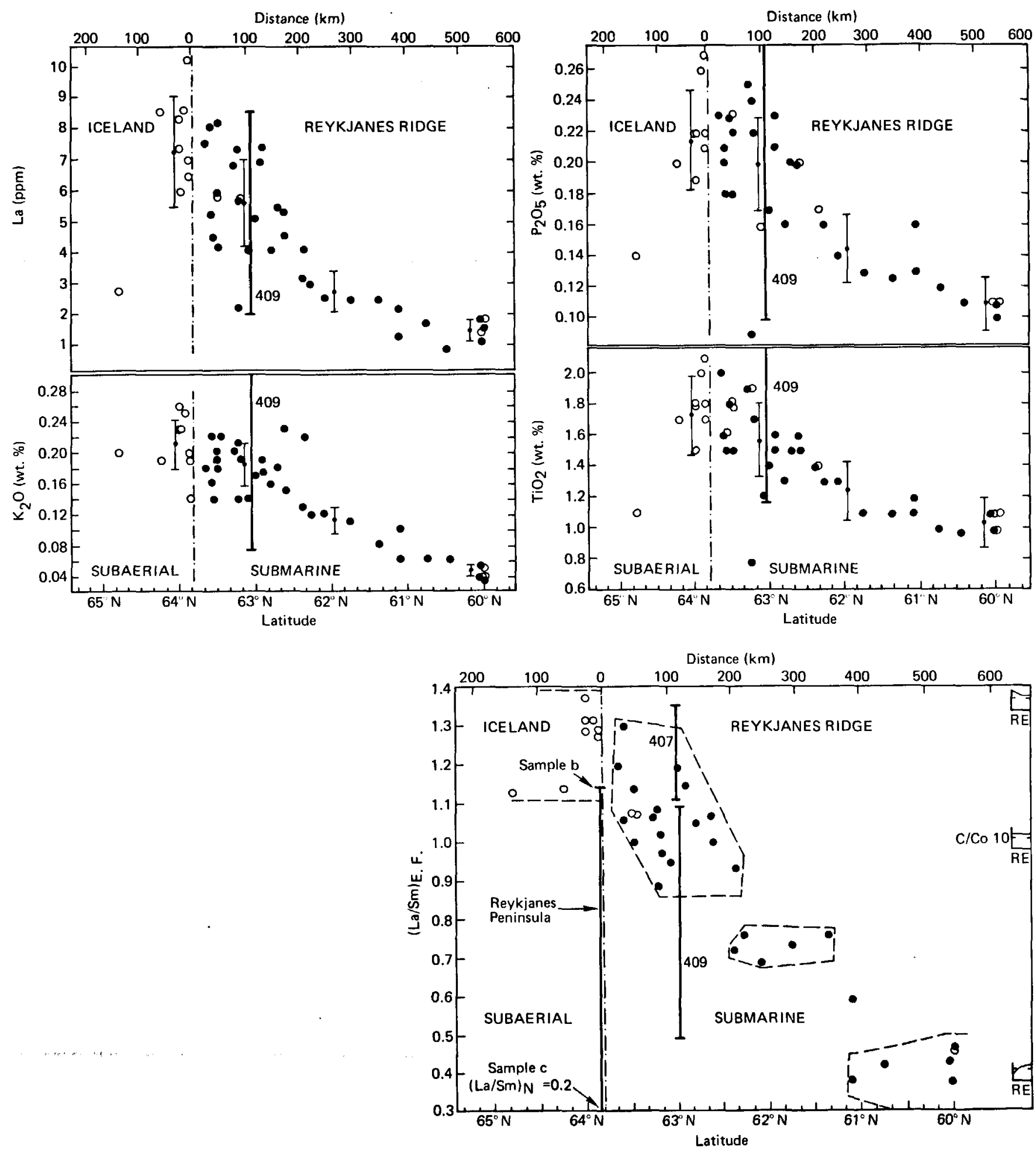

Figure 12. $\mathrm{K}_{2} \mathrm{O}, \mathrm{P}_{2} \mathrm{O}_{5}, \mathrm{TiO}_{2}, \mathrm{La}$, and La/Sm concentration variations along Reykjanes Ridge (Schilling, 1973, Figures 2 and 3). The range of values found within Hole 409 is represented by a bar. Range of La/Sm values found in the Reykjanes Peninsula in Iceland, and in Hole 407 are also reported for comparison. Sample b is from a fissure flow and sample c from a shield volcano (Wood, 1977). All data have been calculated using chondrite values of La $=0.30$ and Sm $=0.21$. 
In Figure $23,{ }^{87} \mathrm{Sr} /{ }^{86} \mathrm{Sr}$ has been plotted against $\mathrm{Sr}$ and $(\mathrm{Ce} / \mathrm{Yb})_{\mathrm{N}}$. This diagram shows that there is good correlation between trace-element variation and isotopic variation similar to that described by O'Nions et al. (1976) for Iceland and Reykjanes Ridge basalts. The large range in ${ }^{87} \mathrm{Sr} /{ }^{86} \mathrm{Sr}$ ratios, and the correlation between this ratio and HYG-element ratios in the magma types of these holes, indicates that the different magma types are probably derived from a range of mantle sources.

Figure 24 shows the range of $\mathrm{TiO}_{2},{ }^{87} \mathrm{Sr} /{ }^{86} \mathrm{Sr}$, and $(\mathrm{La} / \mathrm{Sm})_{N}$ in each of the three holes and at the ridge crest at $63^{\circ} \mathrm{N}$ (Schilling, 1973; Hart et al., 1973), plotted with respect to distance from the ridge crest. This diagram emphasizes the significant within-hole variation, both in terms of crystal fractionation and mantle sources. It also shows that there is not an enrichment in HYG-element ratios or radiogenic isotopes toward the ridge crest (as predicted by the mantle plume model), but rather a general decrease in these parameters. It is evident that a mantle enriched in HYG elements and radiogenic isotopes was productive at the $63^{\circ} \mathrm{N}$ segment of the Reykjanes Ridge at a time (viz., Hole 407 , about 35 to 40 m.y.B.P.) of minimum activity of the postulated mantle plume. It is impossible to reconcile the chemical variation in Holes 407,408 , and 409 with the spatial and temporal concepts of the mantle plume model, as previously stated. It has also been shown that a process involving the simple mixing of two solids or liquids corresponding to the two extremes of the chemical variation (e.g., MORB and an alkali basalt) cannot adequately explain the total range of variation in the Iceland and surrounding MAR area (O'Nions et al., 1976; Langmuir et al., in press).

In order to advance our understanding of the geochemistry of North Atlantic basalts, we need to look more closely at the apparent heterogeneities in the mantle. This will be discussed in a later section, when the data from the other Leg 49 sites have been presented.

\section{THE WESTERN FRACTURED PLATEAU OF THE MAR AT $45^{\circ} \mathrm{N}$ : HOLES 410 AND $410 \mathrm{~A}$}

The crest of the MAR at $45^{\circ} \mathrm{N}$ (Figure 25) forms part of the area studied by the Hudson Geotraverse (Aumento et al., 1971), and basement rocks have been recovered from some 40 dredge stations. The suite includes serpentinized ultramafic rocks as well as tholeiitic, transitional, and alkali basalts, together with some ferrobasalts and high-alumina basalts (Muir and Tilley, 1964; Aumento, 1968; Aumento and Loubat, 1971). The dredged samples have revealed just how complex the tectonics and petrology of the ocean crust formed at an apparently normal segment of the MAR may be. In this area, basalts occur which are characterized by high HYG- and alkali-element concentrations, low K/Rb, $\mathrm{Zr} / \mathrm{Nb}$, etc. (Frey et al., 1968; Hart, 1971; Erlank and Kable, 1976), and high ${ }^{87} \mathrm{Sr} /{ }^{86} \mathrm{Sr}$ ratios (about 0.7032 to 0.7034 ) (White et al., 1975), compared with the MORB basalt type (Hart et al., 1972).

Holes 410 and $410 \mathrm{~A}$ are on magnetic anomaly 5 (about 10 m.y.), west of Meta Mount and northwest of Bald Mountain (Figure 25), and close to dredge station 133 of the Hudson Geotraverse (Figure 26).

\section{Hole 410}

This hole was drilled in 2975 meters water depth, and penetrated 47.5 meters into basement. Two lithostratigraphic units were recovered, both of basaltic breccia. The units can be distinguished on the bases of petrography, chemistry, and volcanogenic character (Figure 27).

Unit 1: This unit is a chaotic breccia which has been interpreted as an autoclastite flow (Varet and Demange, this volume). It consists of sparsely olivine and plagioclase (An70-60) phyric basalt clasts in a limestone matrix. The basalt is tholeiitic (normative hypersthene $=13.14 \%$ ), but rich in alkalis.

Unit 2: This unit consists of a pillow breccia of mugearitic composition ( $\mathrm{MgO} 3$ to $5 \mathrm{wt} \%$; normative nepheline 2 to $4 \mathrm{wt} . \%$; normative plagioclase about $\mathrm{An}_{45}$ ). The phenocryst assemblage consists of clinopyroxene, olivine, and plagioclase. Clinopyroxene is an early phenocryst phase, and has a distinctly alkalic character (Table 14) with a composition plotting close to the diopside/hedenbergite join in the pyroxene quadrilateral (Figure 28). It is rich in $\mathrm{TiO}_{2}$ and $\mathrm{Ca}$-Tschermak's molecule. As shown in Figure 28, this pyroxene lies on the same fractionation trend as that previously described for dredged transitional basalts from this area (Muir and Tilley, 1964). Plagioclase phenocrysts range in composition from An76 to An67 (Table 15), and are rather calcic for such an evolved rock.

\section{Hole 410A}

This hole was drilled 120 meters south of Hole 410 in 2977 meters water depth, and penetrated 49 meters into basaltic basement. In view of the close proximity of the two holes, one might expect similar sequences in both; but the sequences are not similar. The abundant glassy selvages and interflow breccias indicate that the Hole $410 \mathrm{~A}$ section is a pillow complex with three main lithostratigraphic units (Figure 29).

Unit 1: This unit consists of olivine and plagioclase sparsely phyric basalt. Both the olivine and plagioclase phenocrysts are homogeneous in composition (Fo87-85; An75-74) (Tables 15 and 16). Microprobe analyses of glassy selvages (Plate 1, Figure 6) are given in Table 3, and are consistent with the whole-rock analyses; they show slightly lower $\mathrm{CaO}$ and $\mathrm{MgO}$.

Unit 2: This is an aphyric basalt with rare olivine phenocrysts, and is more holocrystalline than the upper unit. It is richer in $\mathrm{MgO}$ and $\mathrm{Ni}$, and the olivine is slightly more magnesian (Foss, Table 16) than the upper unit. The olivines contain magnesiochromite inclusions which are more magnesian (ionic $\mathrm{Mg} / \mathrm{Mg}+\mathrm{Fe}=0.69$ ) and contain less $\mathrm{TiO}_{2}$ and $\mathrm{Fe}_{2} \mathrm{O}_{3}$ and more $\mathrm{Al}_{2} \mathrm{O}_{3}$ than those reported for Unit 4 of Hole 407 (Table 5). One plagioclase microlite from a glass has a more calcic composition ( $A n_{79}$, Table 15) than the phenocrysts of the upper unit.

Unit 3: This unit consists of sparsely olivine phyric basalt with rare plagioclase microphenocrysts. It is more variable than the other units, and there is a tendency toward depletion in $\mathrm{Ni}$ and $\mathrm{MgO}$ and enrichment in $\mathrm{Fe}_{2} \mathrm{O}_{3}{ }^{*}, \mathrm{TiO}_{2}$, and HYG elements within the unit. 


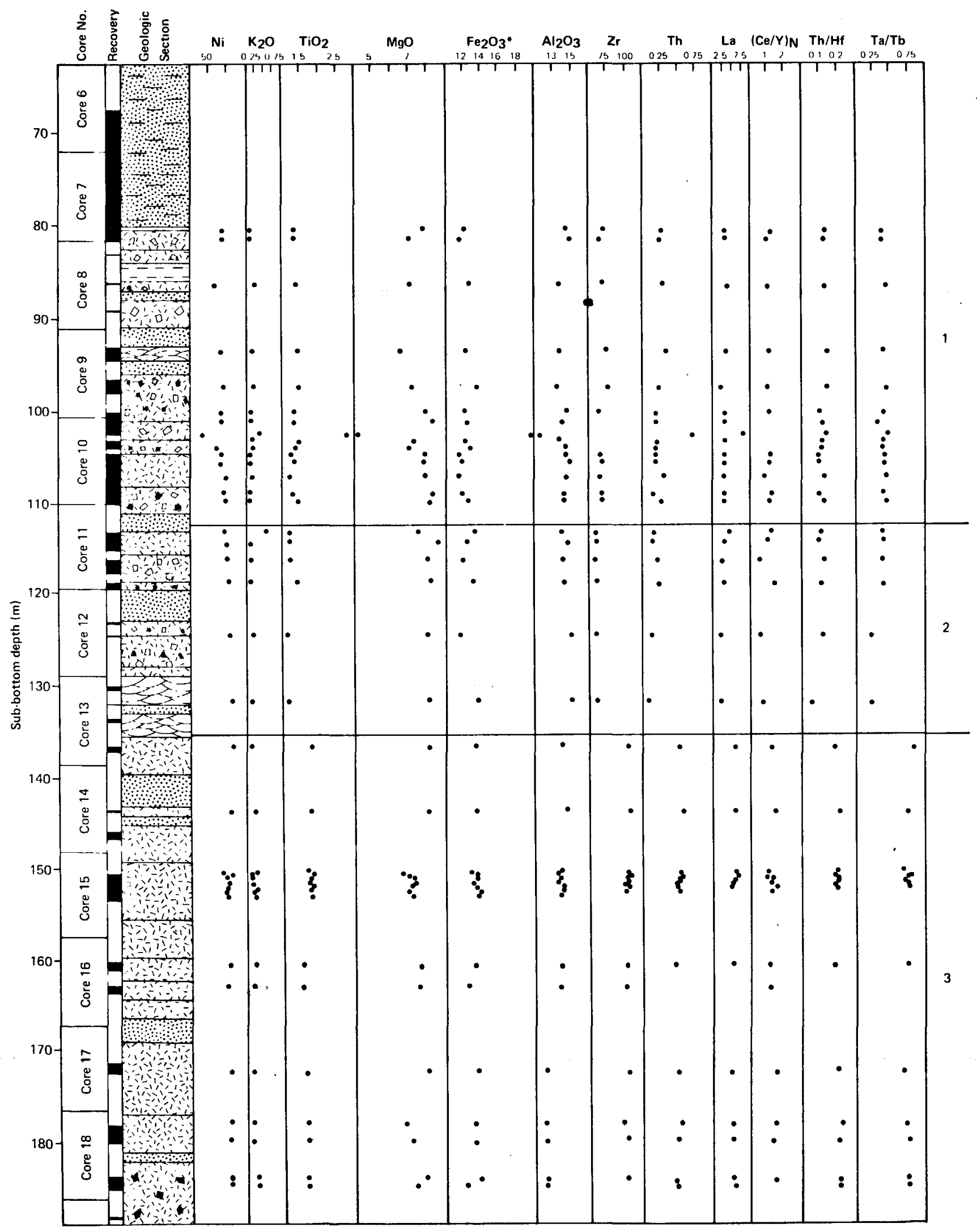

Figure 13. Detailed lithostratigraphic section of Hole 409. Four major geochemical units have been distinguished. For source of analytical data, see Figure 3. 
PETROLOGY, GEOCHEMISTRY, AND MINERALOGY

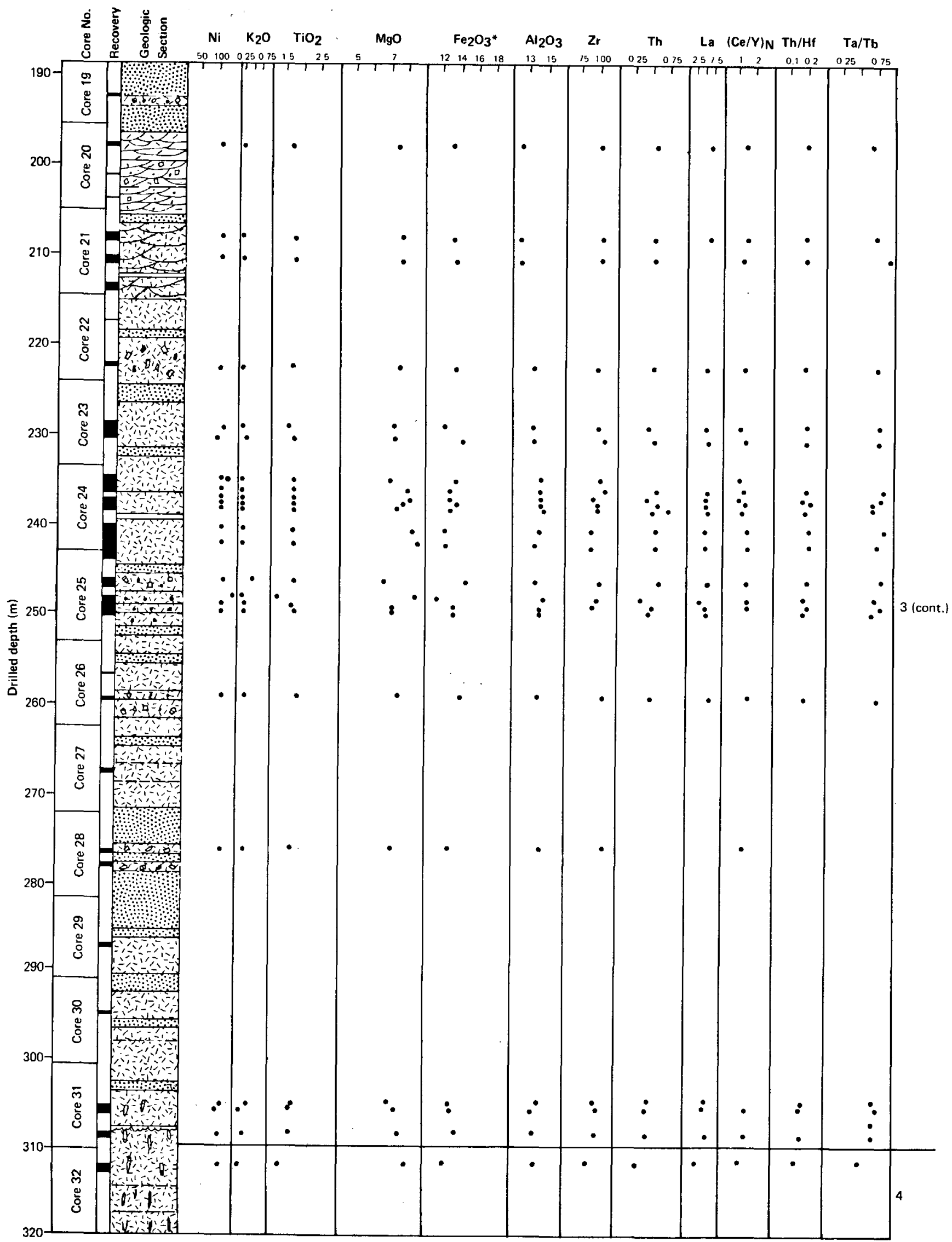

Figure 13. (Continued). 
TABLE 10

TABLE 8

Representative Plagioclase Analyses (Hole 409), Normalized to Eight Oxygens

\begin{tabular}{|c|c|c|c|c|c|c|}
\hline $\begin{array}{c}\text { Sample } \\
\text { (Interval in } \mathrm{cm} \text { ) }\end{array}$ & 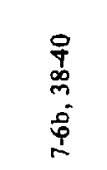 & 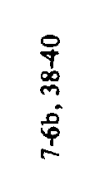 & 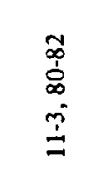 & $\begin{array}{l}\tilde{\infty} \\
\dot{0} \\
\infty \\
\dot{I} \\
\dot{\Xi}\end{array}$ & $\begin{array}{l}\bar{I} \\
\dot{\dot{I}} \\
\dot{\vec{M}} \\
\dot{m}\end{array}$ & $\begin{array}{l}\vec{I} \\
\dot{J} \\
\dot{\Delta} \\
\dot{\Delta}\end{array}$ \\
\hline $\mathrm{SiO}_{2}$ & 46.26 & 50.80 & 47.79 & 50.27 & 50.61 & 51.07 \\
\hline $\mathrm{Al}_{2} \mathrm{O}_{3}$ & 34.22 & 30.55 & 32.32 & 30.86 & 29.83 & 30.30 \\
\hline $\mathrm{CeO}^{*}$ & 0.44 & 0.77 & 0.53 & 0.45 & 0.82 & 0.56 \\
\hline $\mathrm{CaO}$ & 17.47 & 14.50 & 16.89 & 15.15 & 14.38 & 15.12 \\
\hline $\mathrm{Na}_{2} \mathrm{O}$ & 1.07 & 3.21 & 1.85 & 2.52 & 2.78 & 2.74 \\
\hline Total & 99.46 & 99.83 & 99.38 & 99.27 & 98.41 & 99.79 \\
\hline $\mathrm{Si}$ & 2.14 & 2.32 & 2.21 & 2.31 & 2.34 & 2.33 \\
\hline Al & 1.86 & 1.65 & 1.76 & 1.67 & 1.63 & 1.63 \\
\hline lic & 0.02 & 0.03 & 0.02 & 0.01 & 0.03 & 0.02 \\
\hline $\mathrm{Ca}_{\mathrm{a}}$ & 0.86 & 0.71 & 0.84 & 0.75 & 0.71 & 0.74 \\
\hline $\mathrm{Na}$ & 0.10 & 0.28 & 0.17 & 0.23 & 0.25 & 0.24 \\
\hline$\Lambda_{n}$ & 90.04 & 71.40 & 83.47 & 76.87 & 74.09 & 75.33 \\
\hline $\mathrm{Ab}$ & 9.96 & 28.60 & 16.53 & 23.13 & 25.91 & 24.67 \\
\hline $\begin{array}{l}\text { Crystal } \\
\text { type }\end{array}$ & $\mathrm{p}$ (core) & $p($ rim) & $\mathrm{p}$ (core) & $\mathrm{mp}$ & $p$ & $\mathrm{p}$ \\
\hline
\end{tabular}

TABLE 9

Representative Clinopyroxene Analyses (Hole 409), Normalized to Six Oxygens

\begin{tabular}{|c|c|c|c|c|c|}
\hline $\begin{array}{c}\text { Sample } \\
\text { (Interval in } \mathrm{cm} \text { ) }\end{array}$ & 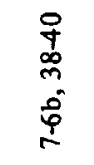 & $\begin{array}{l}\bar{z} \\
\vec{\sigma} \\
\vec{g}\end{array}$ & 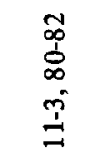 & $\begin{array}{l}\tilde{\infty} \\
0 \\
0 \\
\infty \\
\dot{\mid} \\
\dot{=}\end{array}$ & 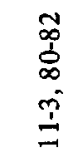 \\
\hline $\mathrm{SiO}_{2}$ & 52.19 & 51.63 & 52.76 & 52.80 & 49.47 \\
\hline $\mathrm{Al}_{2} \mathrm{O}_{3}$ & 3.28 & 6.01 & 2.49 & 0.86 & 2.37 \\
\hline $\mathrm{FeO}^{*}$ & 7.37 & 6.87 & 4.87 & 13.04 & 19.94 \\
\hline $\mathrm{MnO}$ & - & - & - & 0.30 & 0.32 \\
\hline $\mathrm{MgO}$ & 16.75 & 17.58 & 18.23 & 19.16 & 9.99 \\
\hline $\mathrm{CaO}$ & 19.02 & 17.62 & 20.27 & 12.15 & 16.33 \\
\hline $\mathrm{TiO}_{2}$ & 0.58 & - & - & 0.28 & 0.97 \\
\hline $\mathrm{Cr}_{2} \mathrm{O}_{3}$ & 0.69 & - & 0.46 & - & - \\
\hline Total & 99.88 & 99.71 & 99.10 & 98.58 & 99.39 \\
\hline $\mathbf{S i}$ & 1.92 & 1.88 & 1.94 & 1.98 & 1.93 \\
\hline $\mathrm{Al}^{\mathrm{IV}}$ & 0.08 & 0.12 & 0.06 & 0.02 & 0.07 \\
\hline $\mathrm{Al}^{\mathrm{VI}}$ & 0.06 & 0.14 & 0.05 & 0.02 & 0.04 \\
\hline $\mathrm{Fe}$ & 0.23 & 0.21 & 0.15 & 0.41 & 0.65 \\
\hline Mn & - & - & - & 0.01 & 0.01 \\
\hline $\mathrm{Mg}$ & 0.92 & 0.95 & 1.00 & 1.07 & 0.58 \\
\hline $\mathrm{Ca}$ & 0.75 & 0.69 & 0.80 & 0.49 & 0.68 \\
\hline $\mathbf{T i}$ & 0.02 & - & - & 0.01 & 0.03 \\
\hline $\mathrm{Cr}$ & 0.02 & - & 0.01 & - & - \\
\hline $\mathrm{Mg} / \mathrm{Mg}+\mathrm{Fe}^{2+} \%$ & 80.20 & 82.02 & 86.96 & 72.35 & 47.17 \\
\hline Wo & 39.58 & 37.16 & 41.01 & 24.81 & 35.66 \\
\hline En & 48.46 & 51.54 & 51.30 & 54.41 & 30.35 \\
\hline Fs & 11.96 & 11.30 & 7.69 & 20.79 & 33.99 \\
\hline $\begin{array}{l}\text { Crystal } \\
\text { type }\end{array}$ & p & p & p & $\mathrm{mp}$ & g \\
\hline
\end{tabular}

\begin{tabular}{|c|c|c|c|}
\hline $\begin{array}{c}\text { Sample } \\
\text { (Interval in } \mathrm{cm} \text { ) }\end{array}$ & $\begin{array}{l}0 \\
+ \\
0 \\
0 \\
0 \\
\vdots \\
0\end{array}$ & $\begin{array}{l}\overrightarrow{\mathfrak{z}} \\
\dot{J} \\
\vec{z} \\
\dot{\mathfrak{m}}\end{array}$ & 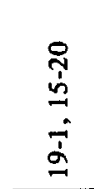 \\
\hline $\mathrm{SiO}_{2}$ & 39.05 & 39.26 & 38.92 \\
\hline $\mathrm{FeO}^{2}$ & 18.15 & 18.44 & 19.24 \\
\hline $\mathrm{MnO}$ & 0.30 & - & 0.26 \\
\hline $\mathrm{MgO}$ & 42.36 & 41.35 & 41.08 \\
\hline $\mathrm{CaO}$ & 0.24 & 0.36 & 0.35 \\
\hline $\mathrm{CoO}$ & 0.45 & 0.24 & 0.24 \\
\hline Total & 100.55 & 99.65 & 100.09 \\
\hline $\mathbf{S i}$ & 0.99 & 1.01 & 1.00 \\
\hline $\mathrm{Fe}$ & 0.39 & 0.40 & 0.41 \\
\hline $\mathrm{Mn}$ & 0.01 & - & 0.01 \\
\hline $\mathbf{M g}$ & 1.61 & 1.58 & 1.57 \\
\hline $\mathrm{Ca}$ & 0.01 & 0.01 & 0.01 \\
\hline Co & 0.01 & 0.01 & 0.01 \\
\hline $\mathrm{Mg} / \mathrm{Mg}+\mathrm{Fe}^{2+} \%$ & 80.61 & 79.98 & 79.19 \\
\hline $\begin{array}{l}\text { Crystal } \\
\text { type }\end{array}$ & $\mathrm{p}$ & p & $\mathrm{mp}$ \\
\hline
\end{tabular}

TABLE 11

Least-Squares Crystal Fractionation Solution for Units 1 and 2, Hole 409

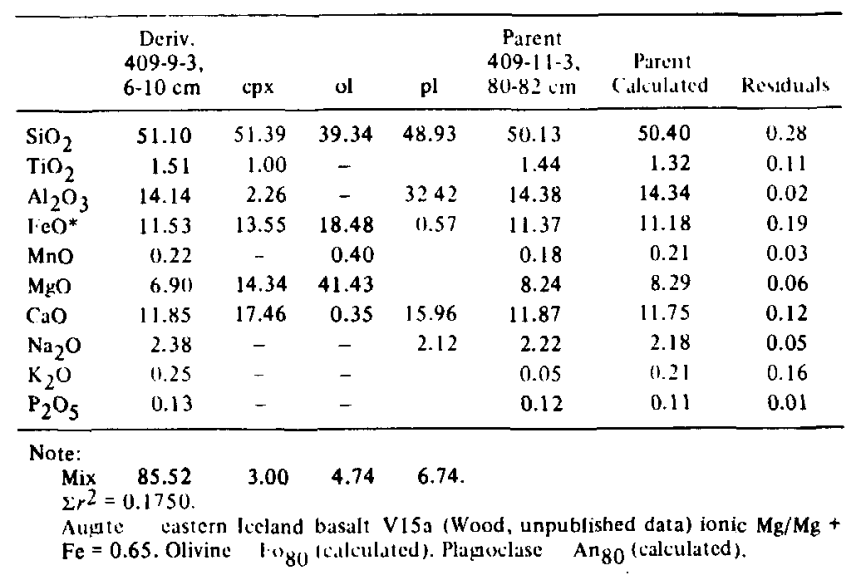

The major-element variation diagram (Figure 30), biaxial plots of HYG elements versus less incompatible trace elements (Figure 31), and Masuda-Coryell REE diagrams (Figure 32) show the relationships between the units of Holes 410 and 410A. There is considerable within-hole variation, as for the holes of the $63^{\circ} \mathrm{N}$ transect. Unit 2 of Hole 410 cannot be derived by closed-system crystal fractionation from Unit 1 of Hole 410, because of the large differences in HYG-element ratios. Although there is less variation between the units of Hole $410 \mathrm{~A}$, it is still not possible to relate them by crystal fractionation processes. In both holes, it is the upper unit that has the lowest HYG-element ratios, similar in both units. 
PETROLOGY, GEOCHEMISTRY, AND MINERALOGY

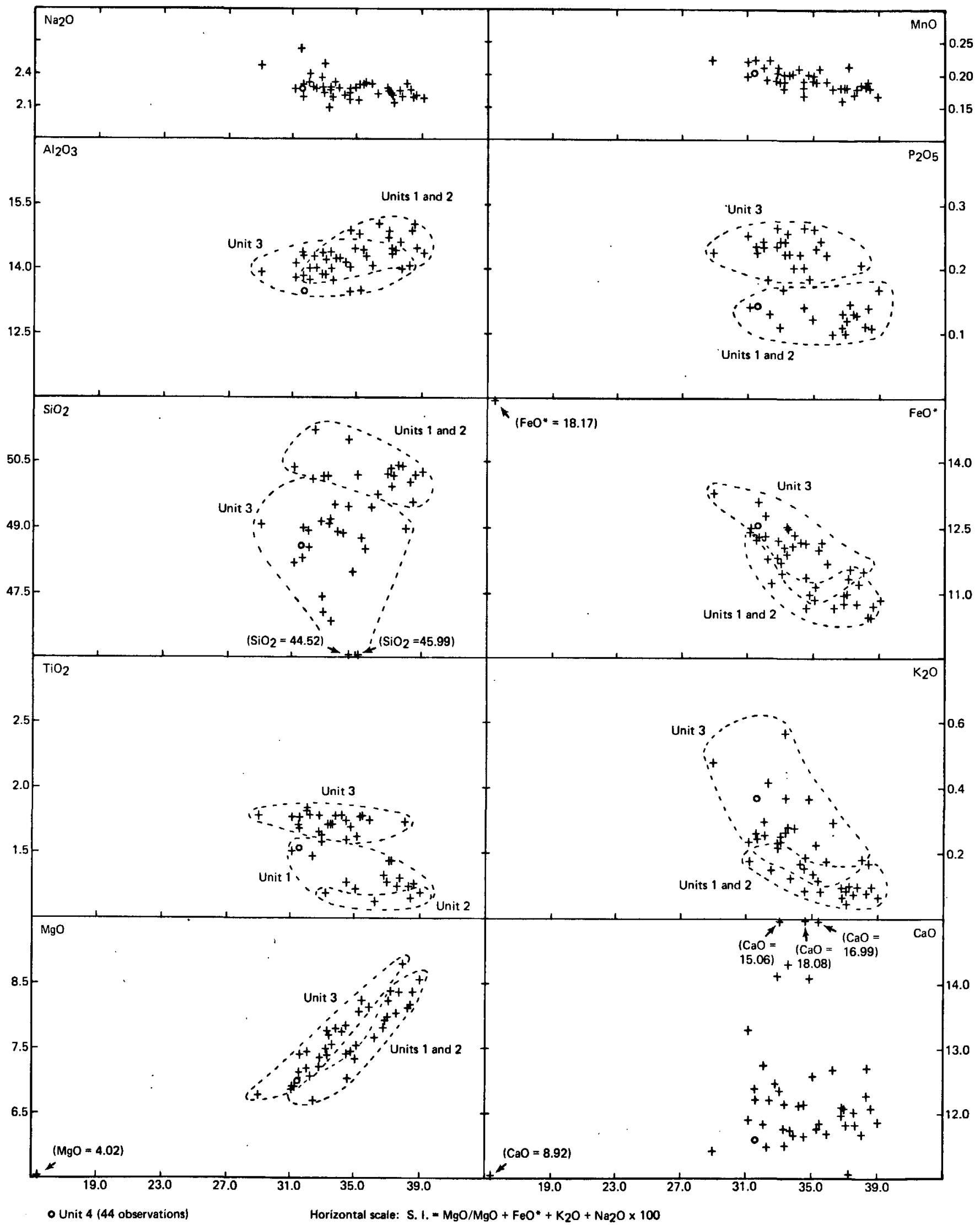

Figure 14. Variation diagram for major elements in Hole 409, using S.I. $\left(=\mathrm{MgO} / \mathrm{MgO}+\mathrm{FeO}^{*}+\mathrm{Na}_{2} \mathrm{O}+\mathrm{K}_{2} \mathrm{O}\right)$. The geochemical units shown in Figure 13 have been distinguished. 


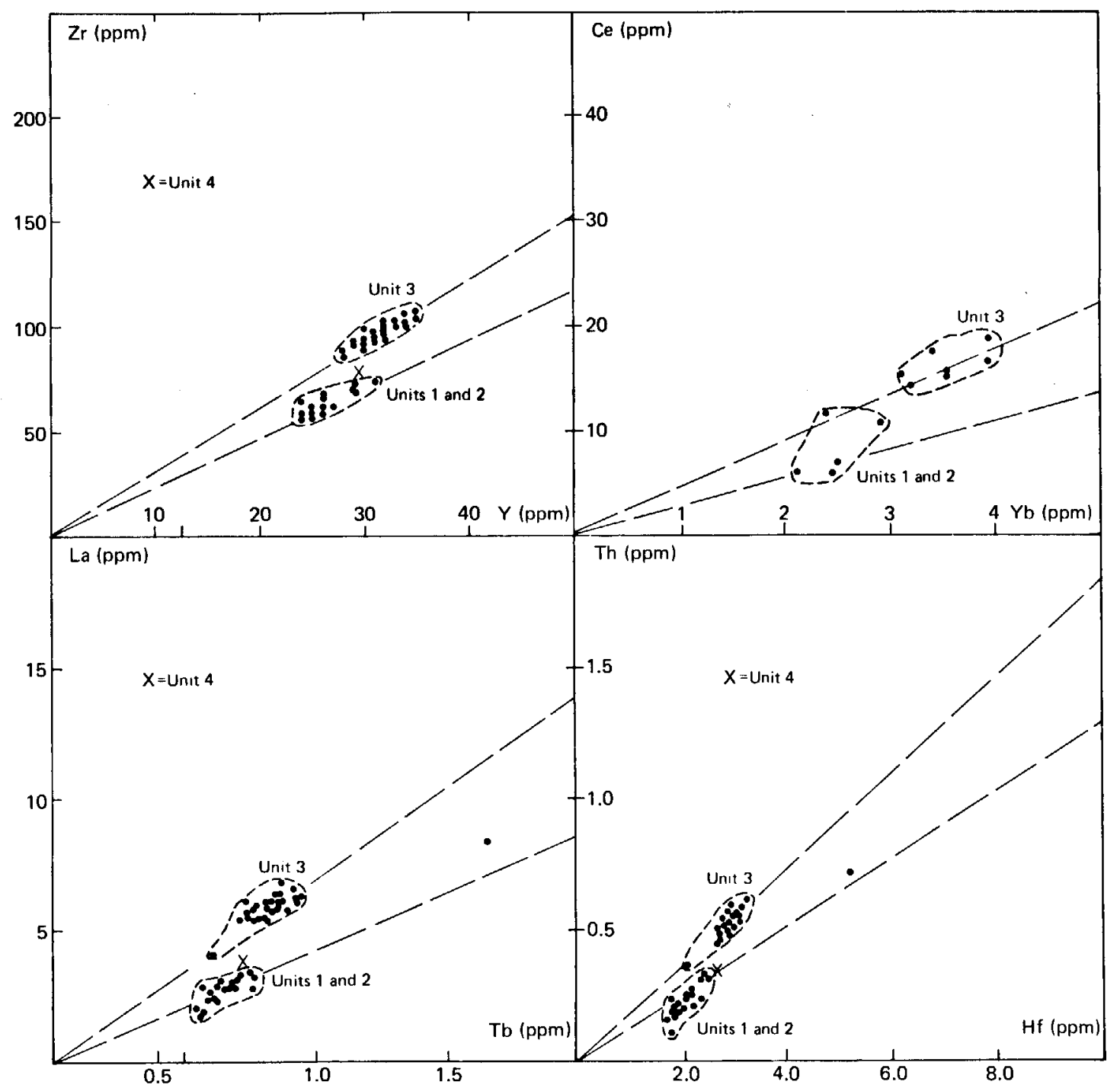

Figure 15. HYG-element plots for Hole 409. See Figure 6 for source of data. Units 1 and 2 group along the same fractionation trend, and differ from Unit 3. Unit 4 (one analysis:cross) has an intermediate ratio.

A wide variety of basalt types has been recovered from the modest penetration of these two holes, but this represents only part of the variation observed in the suite of dredged basalts from the MAR at $45^{\circ} \mathrm{N}$ (Aumento et al., 1971). This is clear from the $\mathrm{FeO}^{*}$-versus-MgO plot of the two sample collections (Figure 33). For compositions with the same $\mathrm{MgO}$ contents, the basalts from Holes 410 and $410 \mathrm{~A}$ are poorer in $\mathrm{FeO}^{*}$ and $\mathrm{TiO}_{2}$, but richer in $\mathrm{K}_{2} \mathrm{O}$, $\mathrm{P}_{2} \mathrm{O}_{5}$, and the $\mathrm{HYG}$ elements than basalts from the Reykjanes Ridge and Iceland. Basalts from the two areas can be readily distinguished on an alkali-silica diagram, although we emphasize that basalts which lie along a more tholeiitic trend have been found in the $45^{\circ} \mathrm{N}$ area (Figure 34).

Further work on the range of basalt types erupted in the $45^{\circ} \mathrm{N}$ area is clearly required before detailed comparisons can be made between this and other areas of the North
Atlantic. Nevertheless, Figure 35 is an attempt to make an initial comparison, with the data available, between $45^{\circ} \mathrm{N}$ and other areas. This diagram will be discussed further when the remaining Leg 49 holes have been described, but we introduce it at this stage to demonstrate the large regional variation in the North Atlantic. Such variation suggests regional heterogeneities in the mantle, as well as a diversity in the processes involved in magma genesis along the MAR.

The high alkali and HYG-element contents and ratios in the basalts recovered from $45^{\circ} \mathrm{N}$ are incompatible with the mantle plume model - the Leg 49 site in this area was selected partly because of its distance from proposed mantle-plume activity. The presence of these basalts at a bathymetrically normal segment of the MAR suggests that such compositions are not restricted to areas of hot-spot activity, as implied by the mantle plume model. 

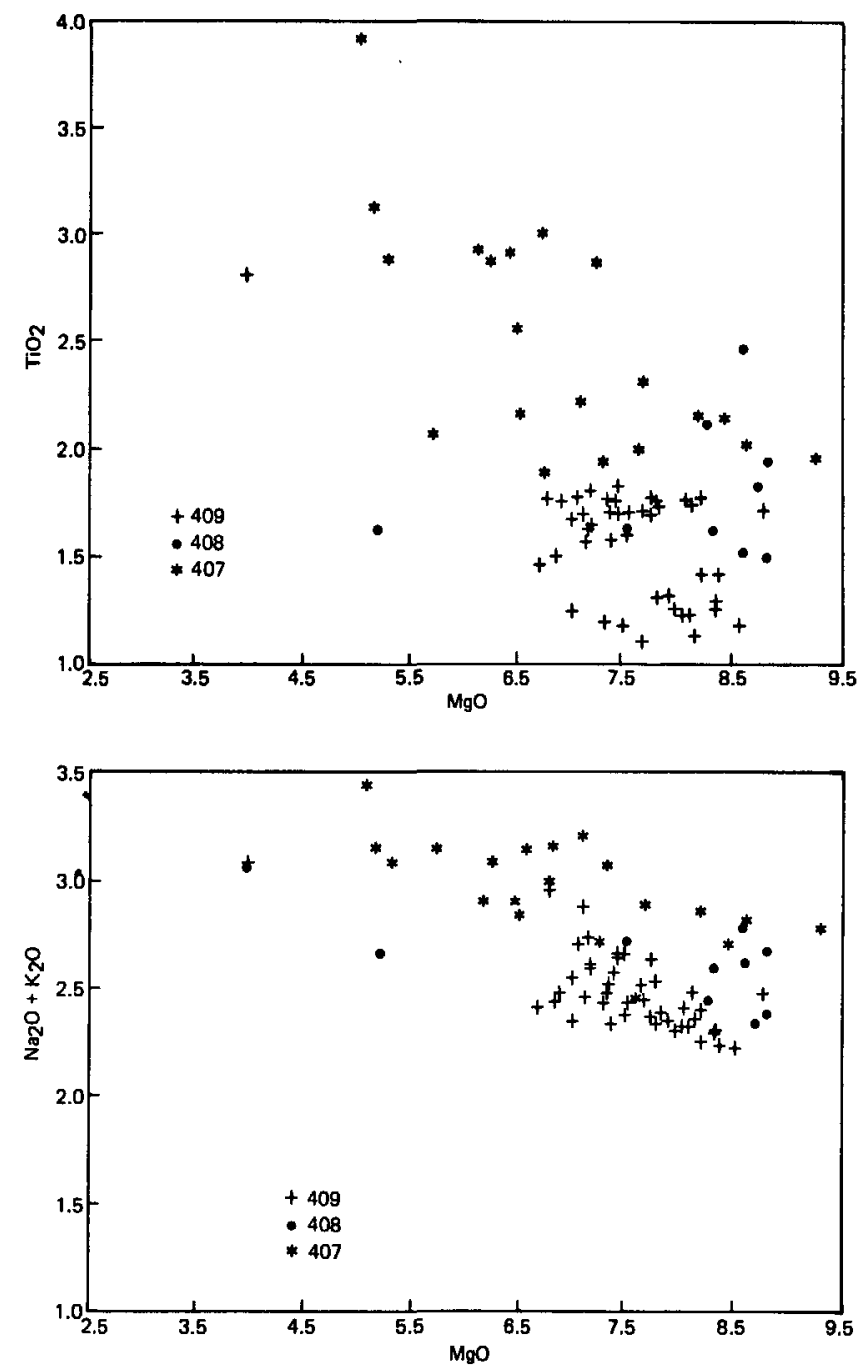

Figure 16. $\mathrm{MgO} / \mathrm{TiO}_{2}$ and $\mathrm{MgO} / \mathrm{Na}_{2} \mathrm{O}+\mathrm{K}_{2} \mathrm{O}$ variation diagrams for Sites 407, 408, and 409. Basalts of Site 407 are more alkaline and Ti-rich, Site 408 basalts have intermediate values.

\section{THE MAR AT $37^{\circ}$ N: HOLES 411, 412, 412A, AND 413}

The four remaining holes drilled into basaltic basement on Leg 49 are in the 36 to $37^{\circ} \mathrm{N}$ area close to the ridge crest (Figure 36), an area which has been studied in more detail than any other segment of the MAR. As for the $63^{\circ}$ and $45^{\circ} \mathrm{N}$ areas, basalts with "anomalous" trace-element and isotope chemistry (with respect to the depleted MORB type) have been previously recovered from this segment of the ridge. Schilling (1975) and White et al. (1975) have suggested, using a suite of dredged rocks, that there is a geochemical gradient along the MAR to the south of the Azores, similar to that proposed south of Iceland (i.e., from HYG-element- and radiogenic isotope-enriched basalt near the Azores to more depleted compositions further south), but extending more than twice the distance (about 1000 $\mathrm{km})$. Similarly, they have related this gradient to overspill of material from a postulated Azores mantle plume and mixing with MORB basalt magmas. The MAR at $36^{\circ}$ to $37^{\circ} \mathrm{N}$ lies in an intermediate position on this geochemical gradient, with ${ }^{87} \mathrm{Sr} /{ }^{86} \mathrm{Sr}$ of approximately 0.7030 and chondritic REE ratios.

The rift valley of the MAR between $36^{\circ} 50^{\prime}$ and $37^{\circ} \mathrm{N}$ (Figure 36 ) has been extensively studied as part of the French-American Oceanographic Undersea Survey (FAMOUS), and the petrology and geochemistry of the lavas and glasses recovered have been well documented (e.g., Bryan and Moore, 1977; White and Bryan, 1977). The FAMOUS sample collection suggests that there is a spatial variation in petrography and basaltic glass composition within the inner rift valley. Hekinian et al. (1976, fig. 5) have produced a schematic map showing the distribution of five basalt types distinguished by their phenocryst assemblages.

Basaltic crust produced at this segment of the MAR has also been sampled on DSDP Leg 37, during which depths of more than 100 meters were drilled into basement at four sites ( 332 through 335 ) on a west-northwest transect ranging from 3.5 to $15 \mathrm{~m} . \mathrm{y}$. (Figure 37 ). The petrological and geochemical accounts of Leg 37 basalts (DSDP Initial Reports, v. 37, 1977; Bryan et al., 1977; Blanchard et al., 1976; Lambert and Holland, 1977; O'Nions and Pankhurst, 1976) suggest that a similar range of petrographic and geochemical basalt types have been erupted from this segment of the ridge for at least $15 \mathrm{~m} . \mathrm{y}$.

Almost all the basalts sampled from the FAMOUS area and the Leg 37 holes are Mg-rich (generally between 8 and $10 \mathrm{wt} . \% \mathrm{MgO}$ ), and display a large range in petrography: both aphyric and coarsely phyric types are abundant. This contrasts with the $63^{\circ} \mathrm{N}$ and $45^{\circ} \mathrm{N}$ areas of the North Atlantic, where aphyric or sparsely phyric basalts predominate.

The objectives at the Leg 49 sites in this area were to extend the Leg 37 transect to a younger age, in order to study temporal variation in the basalt produced at this segment of the ridge, and to compare the basalt types erupted at the ridge with those erupted in the nearby fracture zone.

\section{Hole 411}

This hole was positioned $10 \mathrm{~km}$ west of the inner rift valley of the FAMOUS area, in a sediment pond within the outer rift (about $1 \mathrm{~m} . \mathrm{y}$. - the youngest basaltic ocean crust drilled to date). The hole was drilled in 1935 meters water depth and penetrated $\mathbf{4 5 . 5}$ meters into basaltic basement, but recovery was less than 10 per cent, owing partly to the denseness and freshness of the basalt. Two petrographically and geochemically distinct lithostratigraphic units have been distinguished (Figure 38).

Unit 1: This unit is a pillow complex consisting of basalt which ranges from aphyric to sparsely olivine phyric, with rare plagioclase microphenocrysts in some samples. There are abundant chrome spinel inclusions in the olivine phenocrysts (Plate 2, Figure 1). The olivine phenocrysts are very magnesian, show a narrow range of compositions (Fos8-85, Table 17), and are relatively poor in Ni compared with other FAMOUS samples (Hekinian et al., 1976). The 


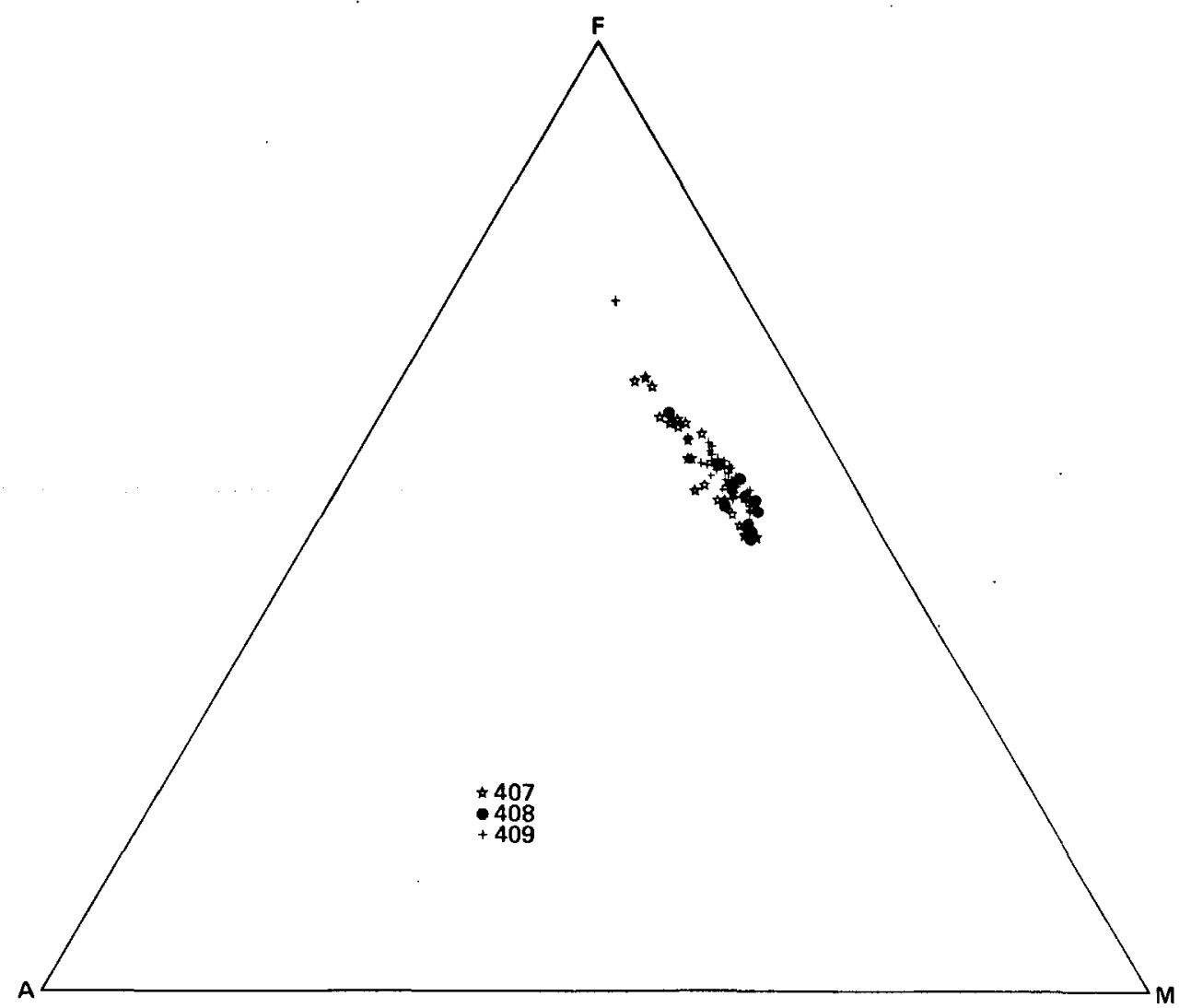

Figure 17. AFM diagram for Reykjanes sites. All rock analyses plot along an iron enrichment trend of tholeiitic affinity. Site 409 samples are richer in alkaline elements. Site 408 samples are intermediate between those of Sites 407 and 409.

chrome spinels are $\mathrm{Mg}$-rich and plot toward the Al-rich limit of the field of magnesiochromite for basalts dredged between $29^{\circ}$ and $40^{\circ} \mathrm{N}$ of the MAR (Sigurdsson and Schilling, 1976) and for those from DSDP Leg 37 (Sigurdsson, 1977) (Table 18; Figures 39 and 40). The plagioclase microphenocrysts vary in composition from An83 to An72 (Table 19). This basalt is characterized by high $\mathrm{MgO}$ and $\mathrm{Ni}$ and low HYG-element contents and ratios.

Unit 2: This unit consists of coarsely plagioclase and olivine phyric basalts, sometimes with sparse augite phenocrysts. The basalts contain between 10 and 20 per cent plagioclase megacrysts ( 2 to $4 \mathrm{~mm}$ diameter) which are highly zoned with very calcic (Ang2-89) resorbed cores and less calcic rims (An79-78) (Table 19) (Plate 2, Figure 2). The olivine compositions are similar to those of Unit 1 , with microphenocrysts of Fos5-84 and rare megacrysts of more magnesian composition (Table 17). The clinopyroxene phenocrysts and microphenocrysts have a homogeneous diopsidic-augite composition (ionic $\mathrm{Mg} / \mathrm{Mg}+\mathrm{Fe}=85$, Table 20).

Of the basalts recovered during Leg 49 in the 36 to $37^{\circ} \mathrm{N}$ area, none that contain clinopyroxene phenocrysts or microphenocrysts contain chrome spinels as well. This suggests a reaction relationship between magnesiochromite and diopsidic augite.

The Unit 2 basalt is characterized by higher $\mathrm{Al}_{2} \mathrm{O}_{3}$ (probably resulting mainly from accumulation of plagioclase phenocrysts) and lower $\mathrm{MgO}$ and $\mathrm{Ni}$ than Unit 1. Units 1 and 2 cannot be simply related by the dilution effect of plagioclase phenocrysts, since Unit 2 also has higher $\mathrm{TiO}_{2}, \mathrm{~K}_{2} \mathrm{O}, \mathrm{P}_{2} \mathrm{O}_{5}$, and $\mathrm{HYG}$-element contents than Unit 1 (Figures 38 and 41). The different HYG-element ratios of the two units (Figures 42 and 43 ) confirm that they belong to two different magma types.

The range of major- and trace-element chemistry of the two magma types present in Hole 411 is similar to the range of chemistry already described for the FAMOUS area (Bryan and Moore, 1977; White and Bryan, 1977) and the two magma types sampled on Leg 37 , i.e., the normative anorthite-rich and normative diopside-rich magma types of Flower et al. (1977) (magma types A and B of Mitchell and Aumento [1977]). Unit 1 of Hole 411 belongs to magma type $A$ and Unit 2 to magma type $B$. To demonstrate the similarity between the Hole 411 magma types and those previously described from this area, the REE of aphyric members of the two Leg 37 magma types have been included in Figure 43 (stratigraphic unit 332B-5 represents the normative anorthite-rich magma type $A$; stratigraphic unit 332A-2 represents the normative diopside-rich magma type B - Flower et al., 1977).

Magma type A is slightly light REE-depleted, and type B is slightly REE-enriched (relative to chondrite REE ratios). Both types are concave upward in the light REE (Figure 43), and have $(\mathrm{La} / \mathrm{Ce})_{\mathrm{N}}$ ratios (1.14 and 1.54 for types $A$ and $B$, respectively) similar to some of the $45^{\circ} \mathrm{N}$ basalts 
Dots represent the most primitive analyses on each trend.

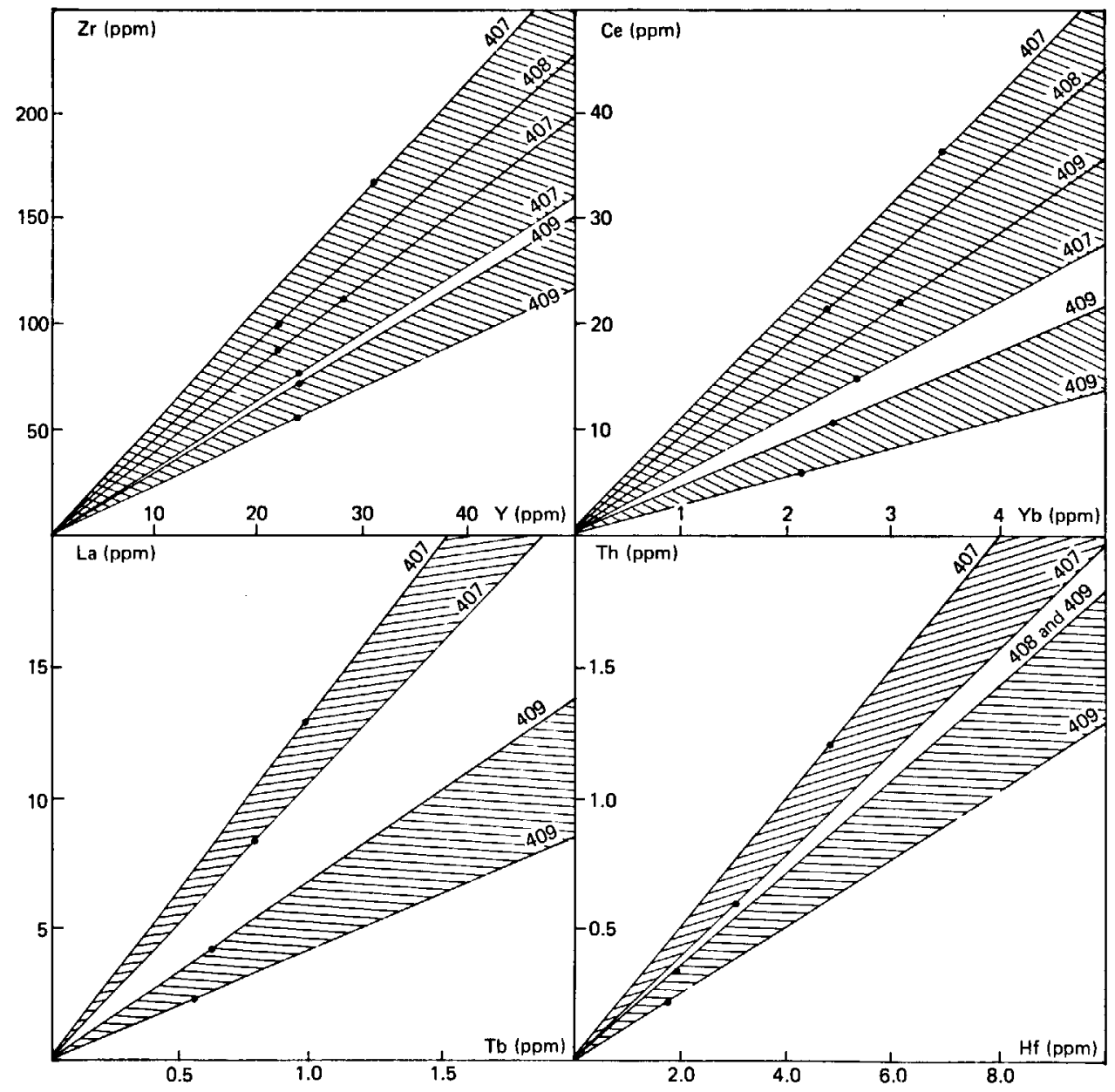

Figure 18. HYG-element fields of variations for rocks of all Reykjanes sites; drawn from Figures 6, 10, and 15. Fields partly overlap, but ratios increase from Site 409 to Sites 408 and 407 , i.e., with increasing distance from ridge axis. Dots represent the most primitive analysis on each trend.

[La/Ce $]_{\mathrm{N}}$ between 1.54 and 2.28 ; Figure 32 ) and to some alkali basalts from oceanic islands, as previously noted by Langmuir et al. (1977). (Ce/Yb) varies from approximately 0.7 in magma type $A$ to 1.4 in magma type $\mathrm{B}$, emphasizing that the basalts from this area are enriched in the heavy REE relative to alkali basalts with the same (La/Ce) ratio.

Figure 44 illustrates the major-element variation in representative samples from the Leg 49 sites in the 36 to $37^{\circ} \mathrm{N}$ area, with respect to that shown by the FAMOUS basaltic glasses and the two aphyric Leg 37 magma types. The plagioclase phyric Hole 411 Unit 2 basalts lie along a plagioclase (about Ango) control line from a liquid composition similar to the Leg 37 magma type $B$. The olivine phyric Hole 411 Unit 1 basalt lies close to an olivine (about Fos9) control line from a liquid similar to Leg 37 magma type $A$. The microprobe analysis of glass from Sample $411-2-2,10-12 \mathrm{~cm}$ (Table 3) also plots close to magma type $A$ in Figure 44 . This figure emphasizes that most of the Hole 411 basalts represent liquid plus crystals, and cannot be taken as liquid compositions.

\section{Holes 412 and $412 A$}

These holes were positioned in the northern part of the valley of fracture zone $B$ to the south of the FAMOUS area (Figure 36), in crust $1.6 \mathrm{~m} . \mathrm{y}$. old. This provides a section in the basaltic crust to the east of the rift valley only about 0.5 m.y. older than that of Hole 411 to the west of the rift valley. The two holes were drilled in 2609 meters water depth, and basalt was first penetrated at 153 meters sub-bottom in Hole 412. The hole penetrated 171.5 meters sub-bottom, and only $35 \mathrm{~cm}$ of basalt were recovered. The basement lithostratigraphy of Hole 412 is reconstructed in Figure 45. Basement was first encountered at 163 meters sub-bottom in Hole $412 \mathrm{~A}$, which penetrated 131 meters of basaltic basement. Twenty-seven flows have been distinguished by shipboard studies and subsequent geochemistry (Figure 46).

\section{Hole 412}

Four flows were sampled in this hole. The top one is an aphyric basalt and the others are coarsely plagioclase, 

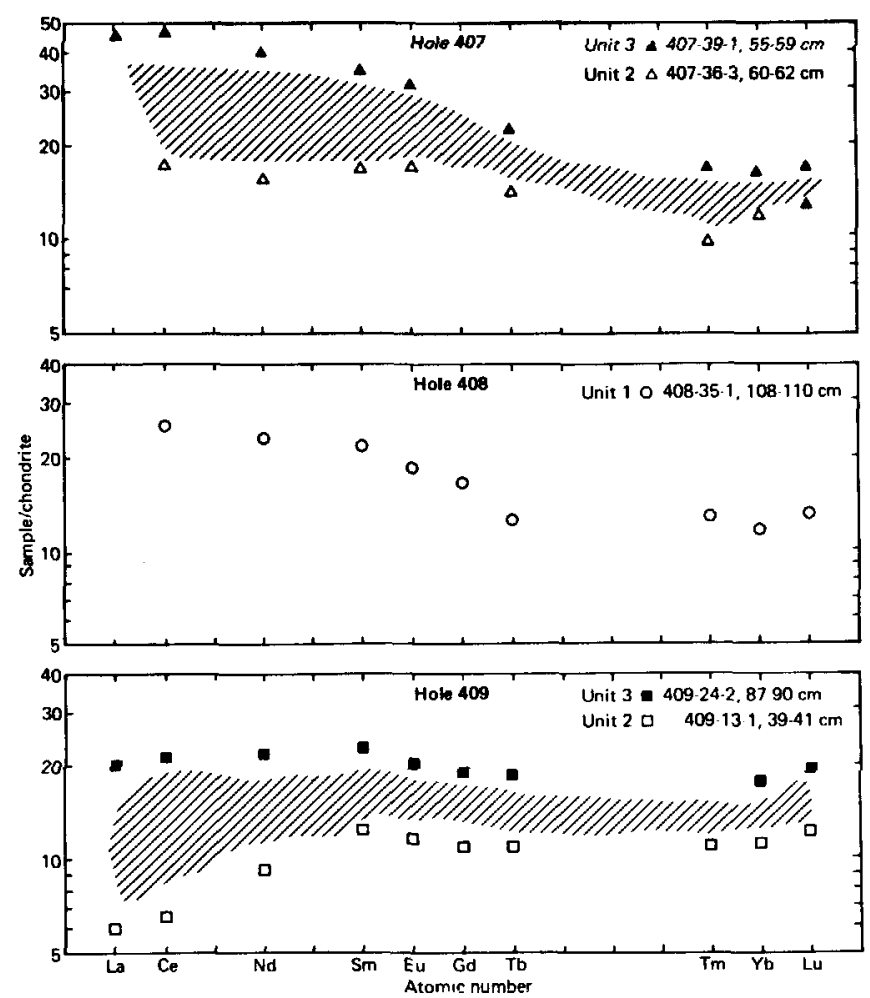

Figure 19. Masuda-Coryell plot for some basalts of Reykjanes sites. Chondrite values used are from Nakamura (1974). The two extreme values observed for each hole have been reported. All data from Wood, except La from Treuil (see Appendices).

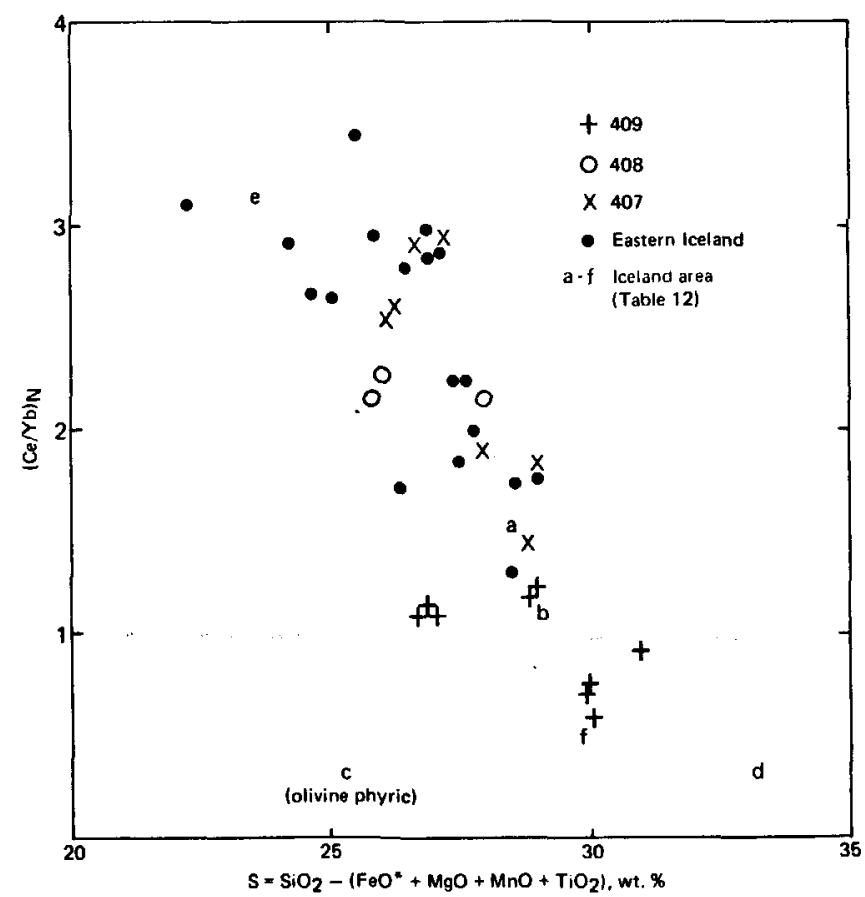

Figure 20. Major-element variation versus $H Y G$ ratio variation in Reykjanes sites. S index is from Dmitriev (1974). Eastern Iceland data are plotted for comparison (from Wood, in press, and Table 12).
TABLE 12

Six Representative Basalts From the Active Zones of Iceland and (the Reykjanes Ridge (major-element analyses are in wt. \%)

\begin{tabular}{lrrrrrr}
\hline & \multicolumn{1}{c}{ a } & \multicolumn{1}{c}{ b } & \multicolumn{1}{c}{$c$} & \multicolumn{1}{c}{ d } & \multicolumn{1}{c}{ e } & \multicolumn{1}{c}{ f } \\
\hline $\mathrm{SiO}_{2}$ & 48.91 & 49.02 & 47.68 & 50.29 & 46.56 & 49.89 \\
$\mathrm{TiO}_{2}$ & 1.53 & 1.23 & 0.53 & 0.66 & 2.02 & 1.30 \\
$\mathrm{Al}_{2} \mathrm{O}_{3}$ & 15.10 & 14.86 & 14.39 & 16.08 & 15.93 & 14.38 \\
$\mathrm{Fe}_{2} \mathrm{O}_{3}$ & 1.58 & 1.88 & 0.88 & 8.98 & 1.61 & 2.43 \\
$\mathrm{FeO}$ & 9.94 & 9.31 & 7.83 & 0.38 & 10.32 & 8.50 \\
$\mathrm{MnO}$ & 0.19 & 0.19 & 0.16 & 0.17 & 0.20 & 0.19 \\
$\mathrm{MgO}$ & 7.59 & 7.91 & 13.45 & 8.18 & 9.00 & 8.35 \\
$\mathrm{CaO}$ & 12.08 & 12.44 & 12.24 & 12.79 & 10.51 & 11.06 \\
$\mathrm{Na}_{2} \mathrm{O}$ & 2.17 & 2.03 & 1.62 & 2.37 & 3.21 & 2.46 \\
$\mathrm{~K}_{2} \mathrm{O}$ & 0.20 & 0.13 & 0.03 & 0.04 & 0.51 & 0.09 \\
$\mathrm{H}_{2} \mathrm{O}^{+}$ & 0.13 & 0.19 & 0.12 & $n . d$. & 0.02 & 1.14 \\
$\mathrm{P}_{2} \mathrm{O}_{5}$ & 0.16 & 0.12 & 0.06 & 0.00 & 0.26 & 0.09 \\
$\mathrm{Total}$ & 99.58 & 99.31 & 98.99 & 100.00 & 100.15 & 99.88 \\
$(\mathrm{Ce} / \mathrm{Yb})_{\mathrm{N}}$ & 1.51 & 1.09 & 0.28 & 0.31 & $(3.12)$ & $(0.50)$ \\
\hline
\end{tabular}

Note: Key to analyses: a is from a lava field east of Myvatn $\left(63^{\circ} 39^{\prime} \mathrm{N}, 16^{\circ} 42^{\prime} \mathrm{W}\right)$ - sample I58 (phenocryst mode: $5.5 \%$ $\mathrm{Pl}, 4.8 \%$ Ol, $1.2 \% \mathrm{Aug}$ ) (Wood, in press). b is from the Reykjanes Peninsula in a fissure $0.5 \mathrm{~km}$ north of Haleyjarbunga $\left(63^{\circ} 51^{\prime} \mathrm{N}, 22^{\circ} 39^{\prime} \mathrm{W}\right)$ - sample $\mathrm{I} 73$ (phenocryst mode: $4.0 \%$ $\mathrm{Pl}, 3.0 \% \mathrm{O} 1,0.5 \% \mathrm{Aug}$ ) (Wood, in press). $\mathrm{c}$ is a picrite from the Reykjanes Peninsula, in a shield volcano east of Skalarfell $\left(63^{\circ} 50^{\prime} \mathrm{N}, 22^{\circ} 40^{\prime} \mathrm{W}\right)$ - sample I61 (phenocryst mode: $10.0 \%$ Ol, $0.7 \%$ Mg-chromite) with $973 \mathrm{ppm} \mathrm{Cr}$ and $525 \mathrm{ppm} \mathrm{Ni}$ (Wood, in press). $\mathrm{d}$ is from Kolbeinsey Island north of Iceland (Sigurdsson and Brown, 1970; O'Nions et al., 1976). This basalt contains phenocrysts of plagioclase (An86-80) and very magnesian olivine (Fo98.8), with groundmass orthopyroxene. $\mathrm{e}$ is the first lava from Surtsey, 1964 (Tilley et al., 1966). REE are extrapolated from values reported by O'Nions et al. (1973) for other Surtsey lavas. No petrographic details are available for this alkali basalt. $\mathrm{f}$ is from the Charlie Gibbs fracture zone (Campsie et al., 1973, table 1, analysis 2), with REE from O'Nions et al. (1976).

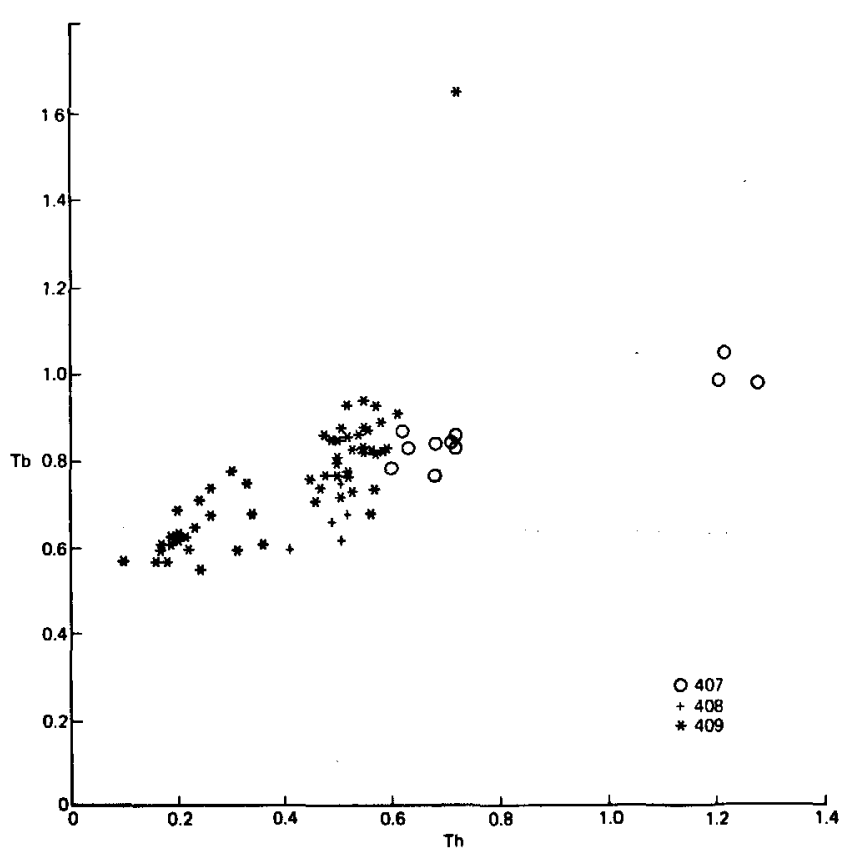

Figure 21. $T b / T h$ (ppm) for analyzed basalts from Leg 49 sites at $63^{\circ} \mathrm{N}$. Analysis by Treuil and Joron (this paper). 

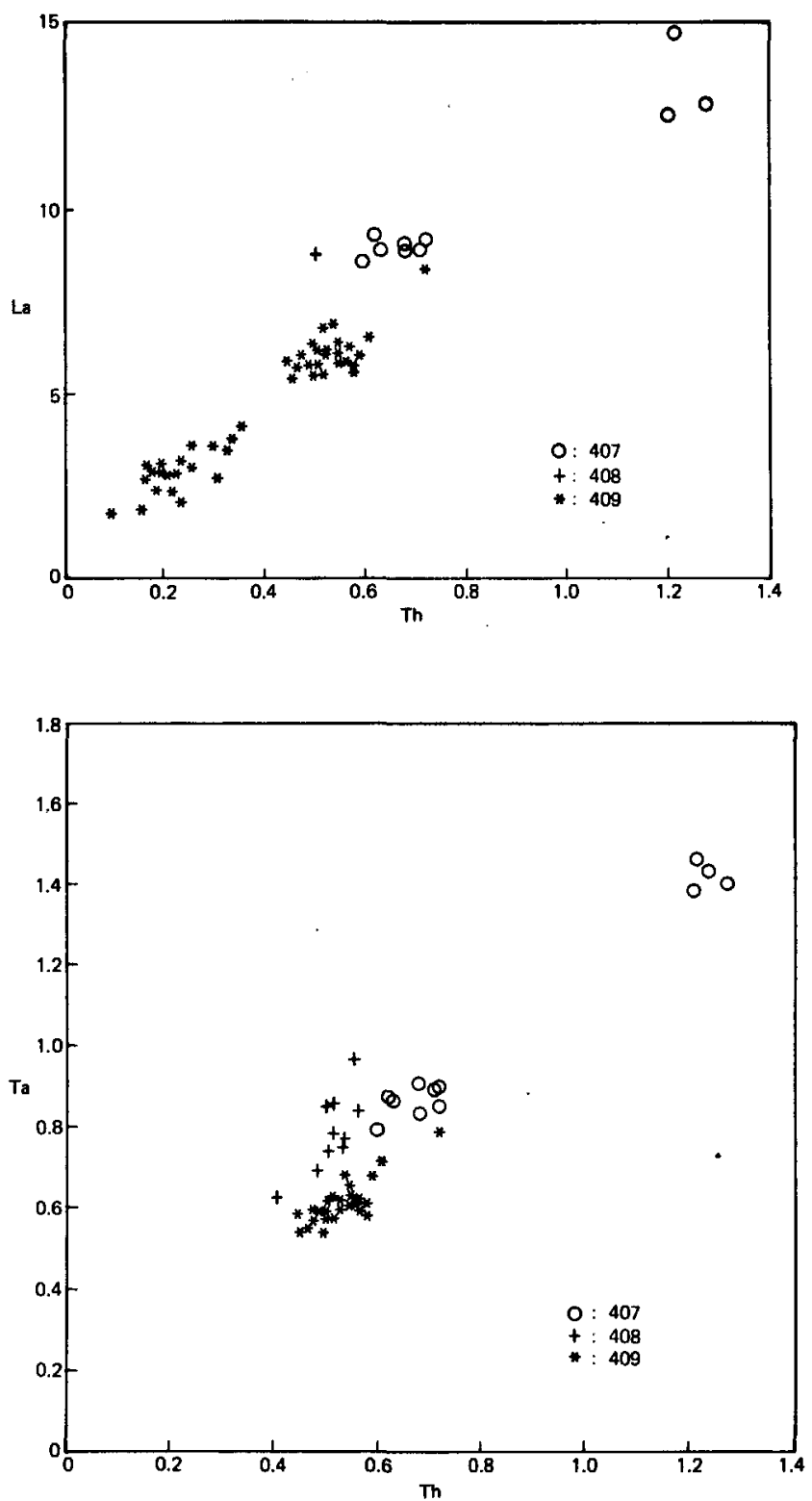

Figure 22. Ta/Th and La/Th (ppm) for analyzed basalts from Leg 49 sites at $63^{\circ} \mathrm{N}$. Analysis by Treuil and Joron (this paper).

clinopyroxene, and olivine phyric. Mineralogy of the basalts from this hole has been studied in detail. The upper aphyric flow contains clinopyroxene showing a quench trend, with limited iron enrichment (Figure 47[a]; Table 21) and plagioclase ranging from An78 to An72 (Figure 48; Table 22). The porphyritic flows contain strongly zoned plagioclase megacrysts with calcic cores (An95-86; Table 22) which are frequently resorbed, surrounded by more sodic rims (An 76.70) (Plate 2, Figure 3). Clinopyroxene phenocrysts are very $\mathrm{Mg}$-rich (ionic $\mathrm{Mg} / \mathrm{Mg}+\mathrm{Fe}=91$ to 88; Table 21), and show a trend toward sub-calcic augite and more $\mathrm{Fe}$-rich groundmass compositions, including pigeonite (Figure 47[b]). Olivine phenocrysts have cores of Fogo-89 and rims of Foss (Table 23). As already mentioned, no chrome spinels occur in these pyroxene phyric basalts (cf. reaction given in section on Hole 411).
TABLE 13

Whole-Rock and Leached ${ }^{87} \mathrm{Sr} /{ }^{86} \mathrm{Sr}$ Ratio for 14 Selected Samples From Holes 407, 408, and 409 (analyses are quoted relative to a value of 0.70800 for the Eimer and Amend $\mathrm{SrCO}_{3}$ standard, all errors quoted are for $2 \sigma$ )

\begin{tabular}{lcc}
\hline Sample (Interval in cm) & Whole-Rock & Leached Powder \\
\hline $407-35-1,42-44$ & $0.70355 \pm 3$ & $0.70348 \pm 5$ \\
$407-36-3,60-62$ & $0.70355 \pm 3$ & $0.70330 \pm 3$ \\
$407-38-2,148-150$ & $0.70397 \pm 3$ & $0.70336 \pm 3$ \\
$407-39-1,55-59$ & $0.70362 \pm 3$ & $0.70339 \pm 8$ \\
$407-45-3,115-120$ & $0.70365 \pm 6$ & $0.70338 \pm 4$ \\
$407-47-1,57-59$ & $0.70364 \pm 3$ & $0.70333 \pm 3$ \\
$408-35-1,108-110$ & $0.70395 \pm 3$ & $0.70330 \pm 5$ \\
$408-37-2,128-133$ & $0.70379 \pm 4$ & $0.70334 \pm 9$ \\
$409-10-1,10-12$ & $0.70301 \pm 3$ & $0.70279 \pm 12^{\mathrm{a}}$ \\
$409-13-1,39-41$ & $0.70340 \pm 3$ & $0.70282 \pm 7$ \\
$409-18-3,88-91$ & $0.70340 \pm 3$ & $0.70296 \pm 4$ \\
$409-23-2,38-41$ & $0.70378 \pm 3$ & $0.70285 \pm 5$ \\
$409-24-2,87-89$ & $0.70299 \pm 5$ & $0.70315 \pm 3$ \\
$409-31-2,80-83$ & $0.70322 \pm 3$ & $0.70291 \pm 5$ \\
\hline
\end{tabular}

${ }^{a}$ Samples being rerun to reduce errors.

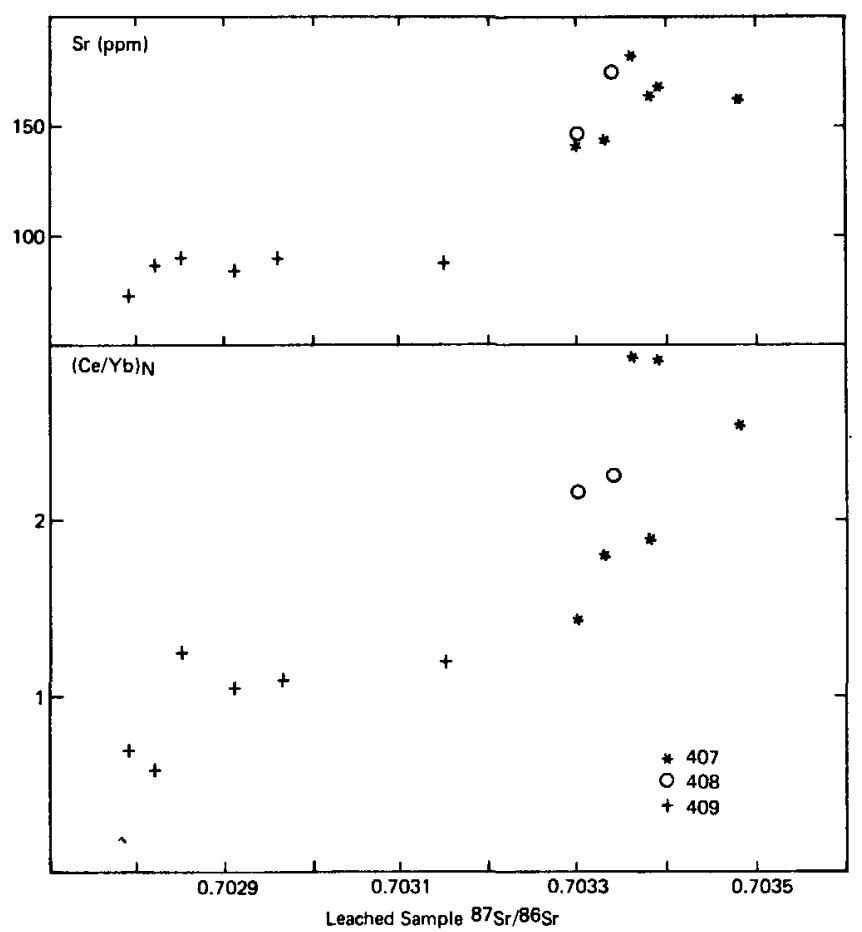

Figure 23. Plate of ${ }^{87} \mathrm{Sr} /{ }^{86} \mathrm{Sr}$ versus $\mathrm{Sr}(\mathrm{ppm})$ and $\mathrm{Ce} / \mathrm{Yb}$ normalized to chondrites for 14 samples. (Source of data: Table 13.)

There is some variation in the major-element chemistry (especially $\mathrm{MgO}, \mathrm{Fe}_{2} \mathrm{O}_{3}{ }^{*}$, and $\mathrm{Al}_{2} \mathrm{O}_{3}$; Figure 45) of the porphyritic lavas, which may be explained by uneven distribution of phenocrysts. The HYG-element ratios are relatively constant and show values similar to Unit 2 of Hole 411 (i.e., magma type B).

\section{Hole 412A}

The upper 50 meters of the basement section of this hole are similar to the porphyritic flows of Hole 412. A coarsely plagioclase, olivine, and clinopyroxene phyric basalt (15 to 


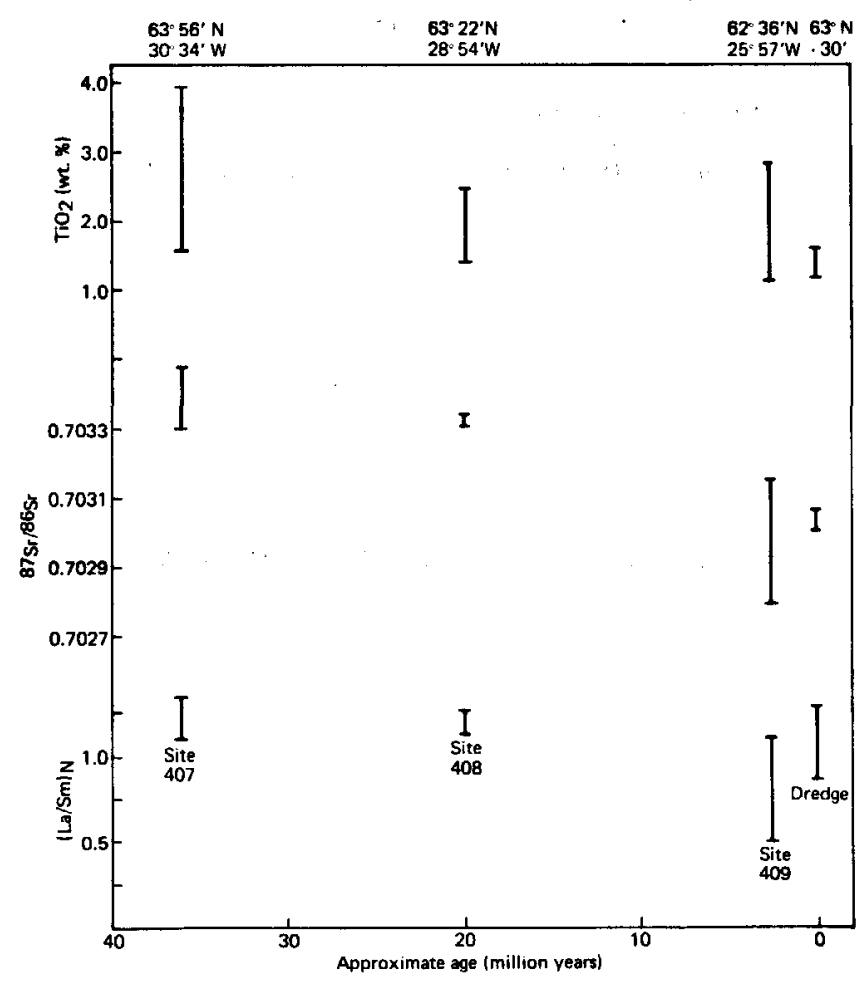

Figure 24. Plot of $\mathrm{TiO}_{2}$ (wt \%), ${ }^{87} \mathrm{Sr} /{ }^{86} \mathrm{Sr}$, and $\mathrm{La} / \mathrm{Sm}$ variation for Sites 407,408 , and 409 basalts and for dredged basalts along the Reykjanes Ridge at $63^{\circ} \mathrm{N}$, versus age and distance from the axis (cf. Figure 2). Source of analytical data: this paper and Schilling (1973) and Hart et al. (1973). ( La/Sm $)_{N}$ values for Site 408 have been extrapolated from $(\mathrm{Ce} / \mathrm{Sm})_{N}$ data.

$25 \%$ phenocrysts) predominates in this part of the hole (Plate 2, Figure 4). The compositional variation in the phenocrysts is similar to that of Hole 412 (Tables 21 to 23). The most calcic plagioclases and the most magnesian olivines and clinopyroxenes of Holes 412 and $412 \mathrm{~A}$ occur in these porphyritic basalts. Figure $47(\mathrm{c})$ shows the range of clinopyroxene phenocryst and microphenocryst compositions in several basalts from Holes 412 and 412A, together with some from Unit 2 of Hole 411 . The clinopyroxene phenocrysts and microphenocrysts of eight samples from the $63^{\circ} \mathrm{N}$ holes have been plotted in Figure 47(d) for comparison. The $63^{\circ} \mathrm{N}$ clinopyroxenes tend to be more Fe-rich and follow a trend closer to the diopside/hedenbergite join than those from the $37^{\circ} \mathrm{N}$ area. The pyroxenes plotted in Figure 47 should be compared with the alkalic pyroxenes in Unit 2 of Hole 410 (Figure 28).

The basalts below 50 meters of the basement section in Hole 412A vary from sparsely phyric to aphyric. Sparsely phyric basalts also occur in the upper 50 meters (with the same mineral assemblage as the coarsely phyric types) especially at 185 meters and 190 to 194 meters sub-bottom - and they have a more evolved composition (higher $\mathrm{Fe}_{2} \mathrm{O}_{3} *, \mathrm{TiO}_{2}$, and $\mathrm{HYG}$ elements) than the coarsely phyric types (Figure 46). In the other sparsely phyric basalts from the lower part of the hole, clinopyroxene microphenocrysts are rare or absent. Magnesiochromites occur in some of these basalts (e.g., Sample 412A-9-1, 70-72 cm; Table 24; Plate 2, Figure 5); they are richer in $\mathrm{Cr}_{2} \mathrm{O}_{3}$ and poorer in $\mathrm{Al}_{2} \mathrm{O}_{3}$ than those from Unit 1 of Hole 411 (Table 18; Figure 39). This compositional difference between the spinels of Hole 412A (magma type B) and Hole 411 Unit 1 (magma type $A)$ reflects the differences between the two magma types (magma type $\mathrm{A}$ is richer in $\mathrm{Al}_{2} \mathrm{O}_{3}-$ and hence in normative anorthite - than magma type $B$ ).

No clear geochemical units could be distinguished in this relatively thick sequence of lava flows (131 m) (Figure 46). The basalts of Hole 412A have major-element chemistry similar to those of Hole 412 and Unit 2 of Hole 411 (magma type B, Figure 44). Figure 49 shows that the basalts from Site $\mathbf{4 1 2}$ have constant values for ratios of HYG elements versus less compatible elements, which are the same as those for Unit 2 of Hole 411 (Figure 42). Nevertheless, there is significant variation in major- and trace-element concentrations, which appear to be systematic and permit three cycles to be distinguished (Figure 46). Each cycle is characterized by evolution with time along a trend toward Fe enrichment and $\mathrm{Mg}$ depletion. This is accompanied by enrichment in the HYG-element concentrations and a slight increase in the HYG ratios (Figure 46).

The major-element variation in each cycle can be interpreted in terms of crystal fractionation of the observed phenocryst compositions. A least-squares crystal fractionation solution for the most primitive and evolved compositions analyzed in cycle 2 (compositions $x$ and $y$ in Figures 44 and 49) (Table 25) suggests that 25 per cent crystallization of a mineral assemblage 49 per cent plagioclase: 42 per cent clinopyroxene: 9 per cent olivine may explain the variation. The degree of fractionation is consistent with the enrichment of the HYG elements, and the mineral assemblage explains the transition-element variation (e.g., relatively constant $\mathrm{Co}$, owing to the small proportions of olivine involved in the fractionating mineral assemblage). The slight increase in HYG ratios in the most evolved lavas of the cycle may be explained by the large proportions of clinopyroxene involved in the fractionating mineral assemblage. Clinopyroxene has relatively high solid/liquid partition coefficients for the heavy REE (i.e., the denominators of the HYG-element ratios) (Arth and Hanson, 1975).

\section{Hole 413}

This hole is on the south side of FAMOUS fracture zone B, about $2 \mathrm{~km}$ from Site 412 (Figure 36) on the east side of marine magnetic anomaly 2 (3.5 m.y.), in 2608 meters water depth. Basement was encountered at 110 meters sub-bottom and penetrated for 39.5 meters; 2.97 meters of basalt was recovered. Two stratigraphic units have been distinguished (between 110 to $118 \mathrm{~m}$ and 126 to $149.5 \mathrm{~m}$ sub-bottom), and both have been reworked (Figure 50). The upper unit is a breccia of glassy to microcrystalline basalt with approximately 10 per cent olivine phenocrysts. Olivine is also present in the groundmass, together with plagioclase and augite. The lower unit is a breccia containing sparsely olivine phyric basalt blocks. The olivine phenocrysts frequently contain chrome spinel inclusions. The texture of 


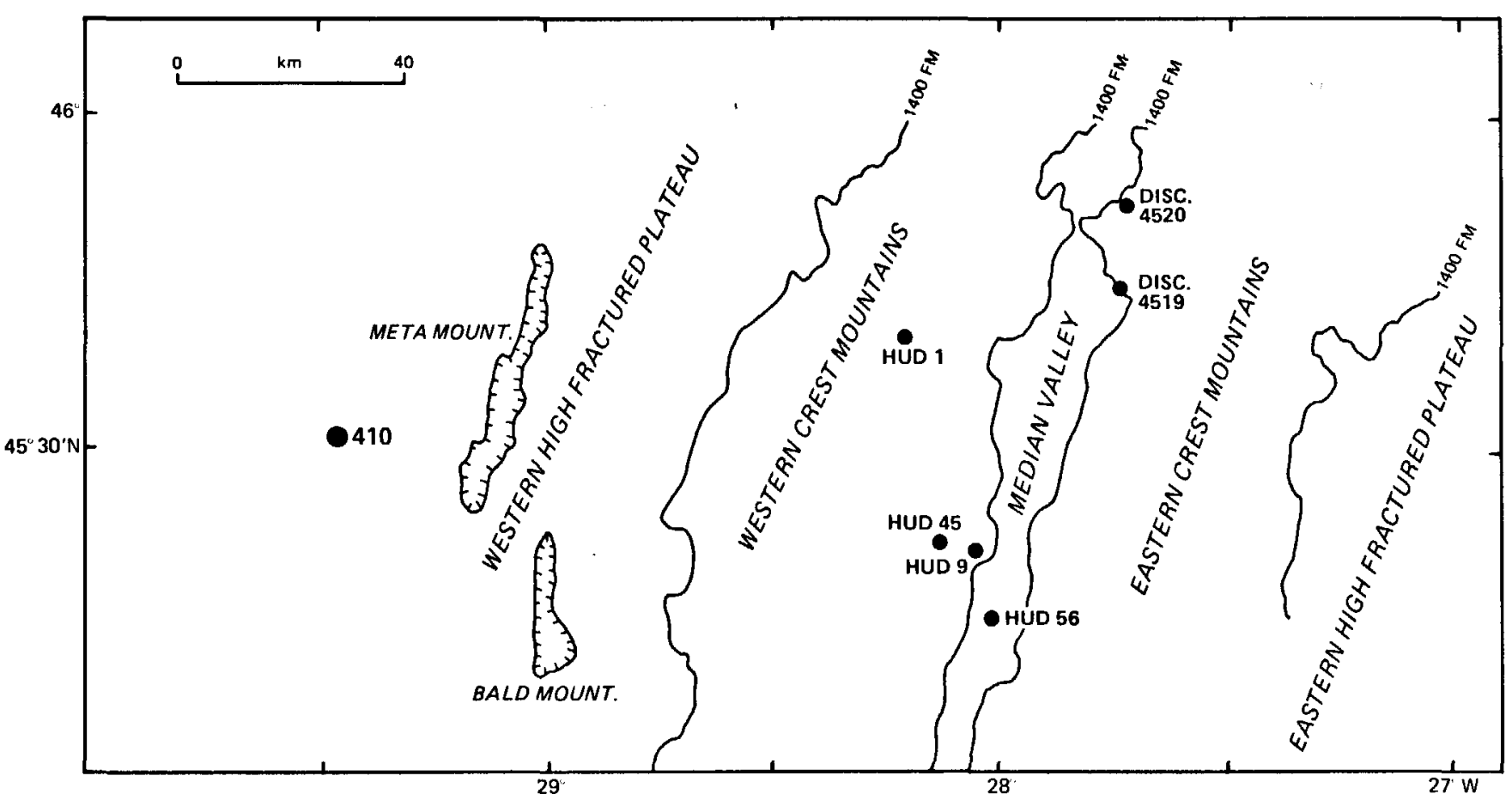

Figure 25. General bathymetric map of the Mid-A tlantic Ridge at $45^{\circ} \mathrm{N}$, showing position of Site 410 and of some dredge stations of Hudson geotraverse. After Aumento et al. (1971).

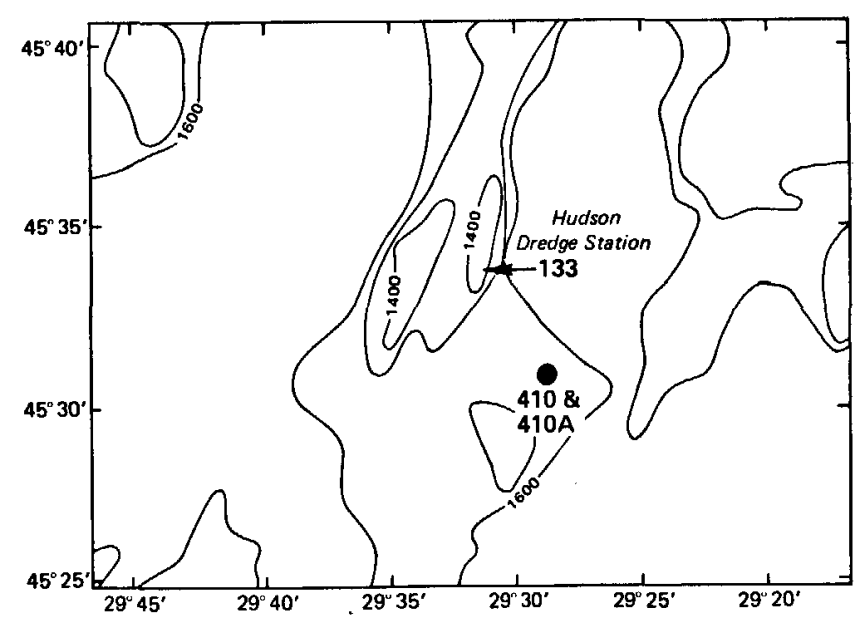

Figure 26. Detailed bathymetric map of Site 410. The nearest dredge station of Hudson geotraverse is indicated.

the basalt is variable, including microcrystalline and "feathery" varieties (Plate 2, Figure 6).

The mineralogy of two samples of the lower unit has been studied in detail by microprobe. Olivine varies from Fos7-84 (Table 23), plagioclase from An75-73 (Table 22), and the chrome spinels are slightly less magnesian and chromian than those from Hole 412A (Table 24, Figures 39 and 40).

The major-element variation diagram (Figure 41) illustrates the rather magnesian nature of these basalts. Most of the samples are relatively rich in $\mathrm{K}_{2} \mathrm{O}$ and $\mathrm{P}_{2} \mathrm{O}_{5}$, except for some of the boulders in the lower part of the section, which have low $\mathrm{TiO}_{2}, \mathrm{~K}_{2} \mathrm{O}$, and $\mathrm{P}_{2} \mathrm{O}_{5}$ and high $\mathrm{Al}_{2} \mathrm{O}_{3}$ (e.g., Sample 413-5-1, 45-50 cm.). The difference between the two basalt types is shown well by the trace-element chemistry (Figures 50 and 51). The alkali-element-rich basalt has high concentrations of the light REE and Th, and high HYG ratios - significantly higher than any other FAMOUS samples (Figure 35). This basalt is similar to the upper units of Holes 410 and $410 \mathrm{~A}$. In contrast, the samples from the lower unit with low $\mathrm{TiO}_{2}$, etc., have very low HYG ratios (Figures 43 and 51) - the lowest of all the Leg 49 samples. This HYG-element-depleted basalt is very similar in major- and trace-element composition to those recovered on DSDP Leg 3 (Frey et al., 1974) and Legs 45 and 46 (Bougault et al., in press), i.e., the basalt type commonly referred to as MORB. Both basalt types recovered from Hole 413 are atypical of the FAMOUS area.

Although it was not apparent from petrographic observations, the two contrasting basalt types found together in this relatively short hole show a wider range of HYG ratios than within any of the other Leg 49 holes. As a result, basalts from Hole 413 cover the entire range of the proposed geochemical gradient along the MAR south of the Azores (Figure 52).

\section{SUMMARY OF THE GEOCHEMICAL AND PETROLOGICAL VARIATION ENCOUNTERED ON LEG 49}

The Leg 49 basalts display different types of chemical variation: most holes show a range of magma types, each following its own crystal fractionation trends; in others $(408,412$, and $412 A)$, only one magma type has been recovered, and the chemical variation may be attributed to crystal fractionation or phenocryst accumulation. Petrographic studies enabled flow units to be distinguished on a scale of approximately 1 to 5 meters (cf. various stratigraphic sections), but the geochemical variation has 


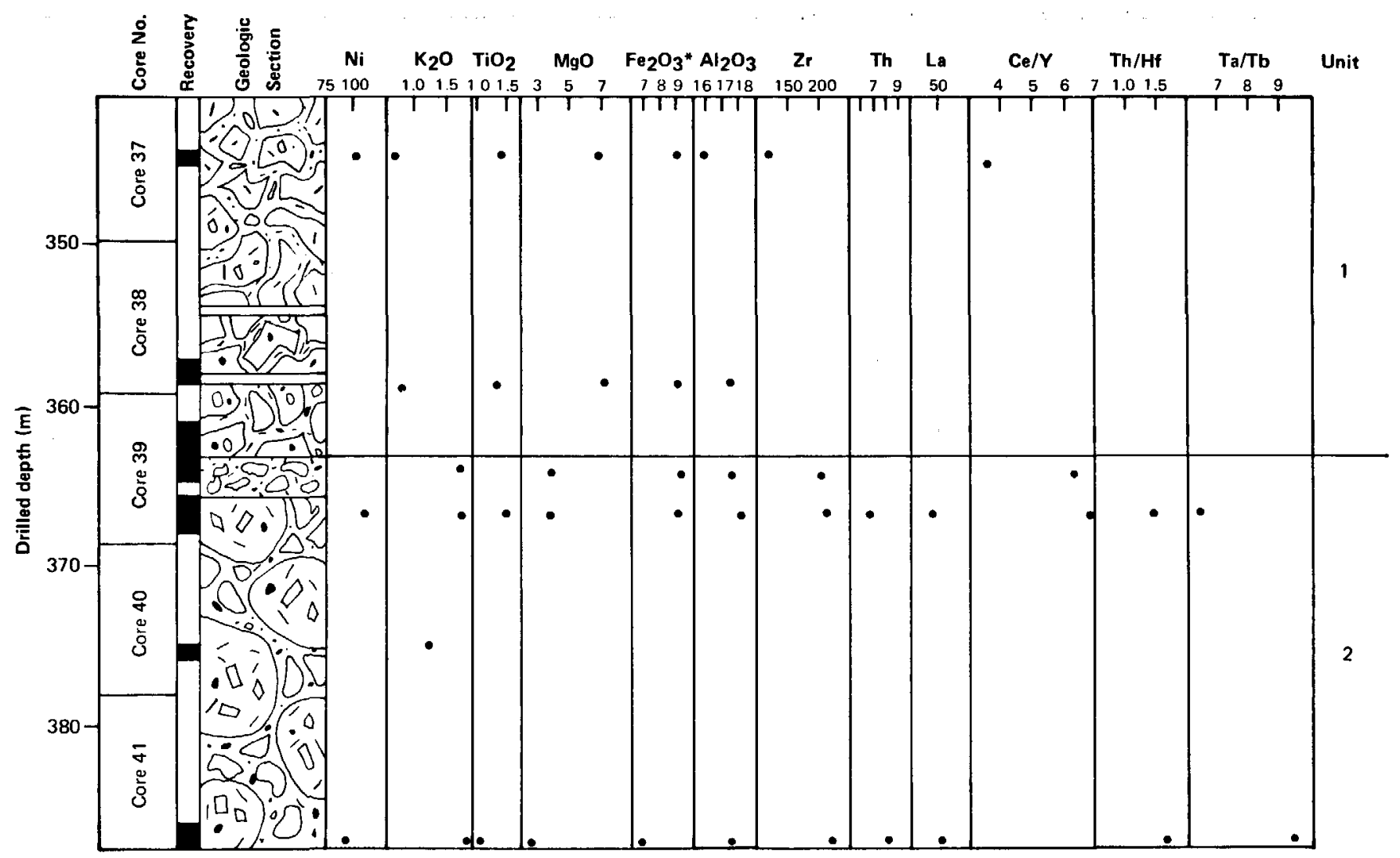

Figure 27. Detailed lithostratigraphic section of Hole 410. See Figure 3 for source of analy tical data.

TABLE 14

Representative Clinopyroxene Analyses From Basalt Sample 410-39-4, 120-124 cm, Normalized to Six Oxygens

\begin{tabular}{|c|c|c|c|}
\hline $\mathrm{SiO}_{2}$ & 49.48 & 49.08 & 49.08 \\
\hline $\mathrm{Al}_{2} \mathrm{O}_{3}$ & 4.32 & 4.67 & 3.97 \\
\hline $\mathrm{FeO}^{*}$ & 6.02 & 7.51 & 9.65 \\
\hline $\mathrm{MgO}$ & 14.55 & 13.80 & 12.21 \\
\hline $\mathrm{CaO}$ & 22.72 & 22.96 & 22.89 \\
\hline $\mathrm{TiO}_{2}$ & 1.10 & 1.81 & 1.89 \\
\hline $\mathrm{CoO}^{-}$ & 0.34 & - & - \\
\hline Total & 98.54 & 99.84 & 99.69 \\
\hline $\mathrm{Si}$ & 1.84 & 1.83 & 1.85 \\
\hline $\mathrm{Al}^{\mathrm{IV}}$ & 0.14 & 0.17 & 0.15 \\
\hline $\mathrm{Al}^{\mathrm{VI}}$ & 0.05 & 0.04 & 0.03 \\
\hline $\mathrm{Fe}$ & 0.19 & 0.23 & 0.30 \\
\hline $\mathrm{Mg}$ & 0.82 & 0.77 & 0.69 \\
\hline $\mathrm{Ca}$ & 0.92 & 0.92 & 0.93 \\
\hline $\mathbf{T i}$ & 0.03 & 0.05 & 0.05 \\
\hline Co & 0.01 & - & - \\
\hline $\mathrm{Mg} / \mathrm{Mg}+\mathrm{Fe}^{2+} \%$ & 81.45 & 79.60 & 69.27 \\
\hline Wo & 47.67 & 47.81 & 48.29 \\
\hline En & 42.46 & 39.98 & 35.82 \\
\hline Fs & 9.87 & 12.21 & 15.89 \\
\hline $\begin{array}{l}\text { Crystal } \\
\text { type }\end{array}$ & $\mathrm{mp}$ & $\mathrm{mp}$ & $\mathrm{mp}$ \\
\hline
\end{tabular}

enabled us to group several flows (between 5 and 30) into broader lithostratigraphic units, numbered in the stratigraphic sections. All the flows within a lithostratigraphic unit may be related to a single magma type by crystal fractionation or accumulation. The boundaries between these units often correspond to major geological breaks, frequently emphasized by changes in paleomagnetic inclination and/or polarity or thick interlayered sediment.

The degree of crystal fractionation occurring within the lithostratigraphic units is variable; e.g., Unit 1 of Hole 409 shows large degrees of fractionation, whereas Unit 3 of Hole 407 shows negligible fractionation. The variation within a unit is not usually systematic, i.e., it does not become progressively more evolved from the base to the top, and no cycles can be defined. But the one very thick unit of Hole $412 \mathrm{~A}$ does show some cyclic variation, and each cycle follows an iron-enrichment trend with time. Also, there appears to be no systematic relationship between the composition of the magma type and depth within a single hole. The same magma type may occur at different positions within one hole (e.g., Units 1 and 3 of Hole 407), and the magma type with the lowest relative HYG-element ratios does not occur in the same position in all the holes.

It appears that the magma types sampled by a single hole only represent some of a range of compositions that are available for eruption in that area; another hole drilled nearby would probably penetrate magma types of different compositions (different HYG ratios) but falling within the 


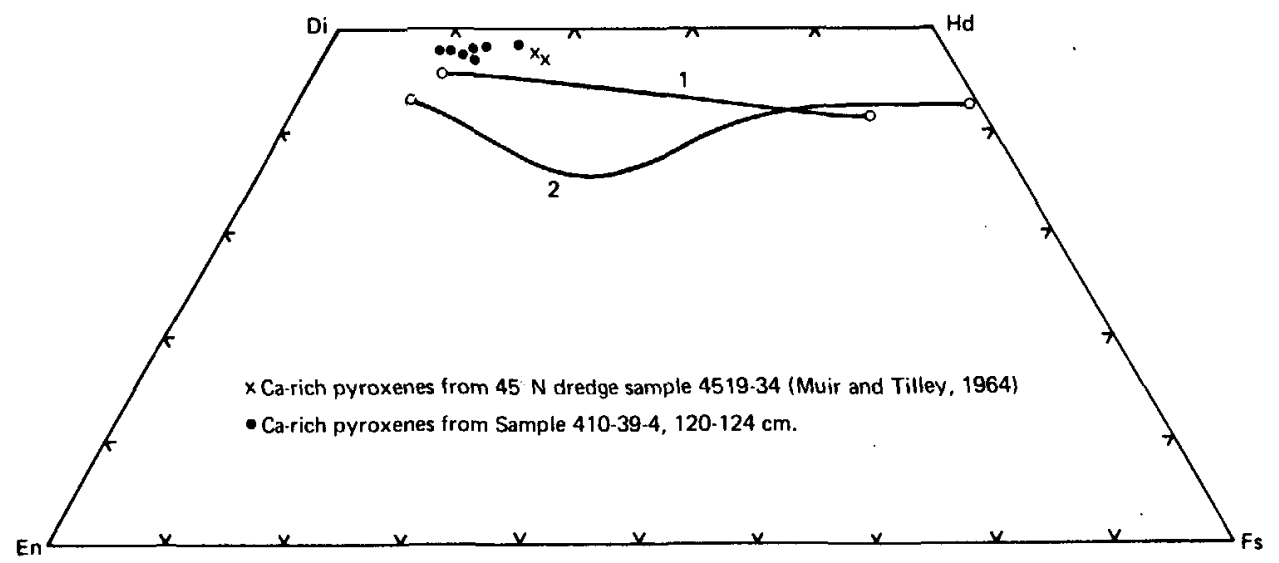

Figure 28. Plot of clinopyroxene composition from Sample 410-39-4, 120-124 cm, in the normative diagram diopside - hedenbergite - enstatite - ferrosilite (filled circles). Sample 4519-34 from $45^{\circ} \mathrm{N}$ (crosses, Muir and Tilley, 1964) is reported for comparison. Both lie on a typical alkaline trend. Crystallization trends for alkali basalts (1: Aoki, 1964) and tholeiites (2: Brown and Vincent, 1963) are included.

TABLE 15

Representative Plagioclase Analyses (Holes 410 and 410A), Normalized to Eight Oxygens

\begin{tabular}{|c|c|c|c|c|}
\hline $\begin{array}{c}\text { Sample } \\
\text { (Interval in } \mathrm{cm} \text { ) }\end{array}$ & 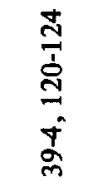 & $\begin{array}{l}\frac{\infty}{5} \\
\stackrel{5}{2} \\
i \\
i\end{array}$ & $\begin{array}{l} \pm \\
I \\
= \\
\stackrel{\sim}{\sim}\end{array}$ & $\begin{array}{c}\dot{m} \\
\dot{m} \\
\dot{q}\end{array}$ \\
\hline $\mathrm{SiO}_{2}$ & 50.82 & 50.30 & 50.37 & 50.34 \\
\hline $\mathrm{Al}_{2} \mathrm{O}_{3}$ & 30.94 & 30.96 & 30.96 & 31.50 \\
\hline $\mathrm{FeO}^{*}$ & - & 0.65 & 0.38 & 0.34 \\
\hline $\mathrm{CaO}$ & 15.17 & 14.51 & 14.18 & 15.79 \\
\hline $\mathrm{Na}_{2} \mathrm{O}$ & 2.75 & 2.62 & 2.74 & 2.23 \\
\hline $\mathrm{K}_{2} \mathrm{O}$ & 0.18 & - & - & 0.14 \\
\hline Total & 99.86 & 99.04 & 98.63 & 100.34 \\
\hline $\mathrm{Si}$ & 2.32 & 2.31 & 2.32 & 2.29 \\
\hline $\mathrm{Al}$ & 1.66 & 1.68 & 1.68 & 1.69 \\
\hline $\mathrm{Fe}$ & - & 0.03 & 0.01 & 0.01 \\
\hline $\mathrm{Ca}$ & 0.74 & 0.71 & 0.70 & 0.77 \\
\hline $\mathrm{Na}$ & 0.24 & 0.23 & 0.24 & 0.20 \\
\hline K & 0.01 & - & - & 0.01 \\
\hline An & 74.48 & 75.36 & 74.08 & 79.01 \\
\hline $\mathbf{A b}$ & 24.46 & 24.64 & 25.92 & 20.18 \\
\hline Or & 1.07 & - & - & 0.82 \\
\hline $\begin{array}{l}\text { Crystal } \\
\text { type }\end{array}$ & $\mathbf{m p}$ & $\mathrm{mp}$ & $\mathbf{m p}$ & $\mathrm{mp}$ \\
\hline
\end{tabular}

same compositional range. Clearly, to define the limits of the compositional range of magma types available for eruption in a given area, it is necessary to drill several holes. If the chemical variation shown by the magma types in a given area is the result of heterogeneities in the mantle source, then the large range of magma types within one hole suggests that the mantle heterogeneities are predominantly vertical.

The diversity of basalt types recovered from the three widely spaced areas in the North Atlantic allows us to discuss the petrological and geochemical variation in the region as a whole. The basalts from the three latitudes $\left(63^{\circ} \mathrm{N}, 45^{\circ} \mathrm{N}\right.$, and $\left.37^{\circ} \mathrm{N}\right)$ can be grouped on an AFM diagram (Figure $53[\mathrm{~A}]$ ): the $37^{\circ} \mathrm{N}$ basalts are the most magnesian, and lie on a trend of moderate iron enrichment; the $45^{\circ} \mathrm{N}$ basalts lie on an alkali-enrichment trend with a relatively constant $\mathrm{Fe} / \mathrm{Mg}$ ratio; the $63^{\circ} \mathrm{N}$ samples follow a marked iron-enrichment trend, with the most primitive basalts richer in iron and poorer in alkalis (especially those of Hole 409 ) than those of $37^{\circ} \mathrm{N}$, reflecting the Fe-Ti-enriched nature of basalts from the Iceland area. The large range of major-element compositions in the Leg 49 basalts is emphasized by their scatter on a projection of the normative tetrahedron (Figure 53[B]). This diagram demonstrates the tholeiitic nature of most of the samples, but cannot distinguish the magma types in detail.

A diagram of two HYG elements with slightly different bulk solid/liquid partition coefficients (e.g., $\mathrm{Zr}$ versus $\mathrm{Nb}$, Figure 54) also enables us to distinguish between basalts from the three latitudes: the $63^{\circ} \mathrm{N}$ basalts have the lowest $\mathrm{Nb} / \mathrm{Zr}$ ratios, those from $45^{\circ} \mathrm{N}$ have the highest, and those from $37^{\circ} \mathrm{N}$ are intermediate. The three largest areas can be grouped on similar diagrams with several different element pairs, and with the areas plotting in the same relative positions. The total variation shown by the Leg 49 basalts, broad though it is, does not include the MORB magma type (except for some of the samples from Unit 2 of Hole 413). This is emphasized by Figure 55, in which La and Hf have been plotted against Th for all the Leg 49 basalts, and the MORB basalts of Legs 45 and $46\left(22^{\circ} \mathrm{N}\right.$, Atlantic) have been included.

It is of interest that for the holes in a given area, those magma types with the lowest $\mathrm{Ce} / \mathrm{Yb}$ ratios also have the lowest $\mathrm{Nb} / \mathrm{Zr}, \mathrm{Th} / \mathrm{La}$, etc. (cf. Figures 18 and 54 for the $63^{\circ} \mathrm{N}$ holes), whereas this is not always so when the different areas are compared - e.g., basalts of Hole 412A have $\mathrm{Ce} / \mathrm{Yb}$ and $\mathrm{La} / \mathrm{Sm}$ similar to or lower than those of Hole 407 , but substantially higher $\mathrm{Nb} / \mathrm{Zr}$, Th/La, etc. This variable behavior of different HYG-element pairs among the three areas suggests that all the Leg 49 magma types 


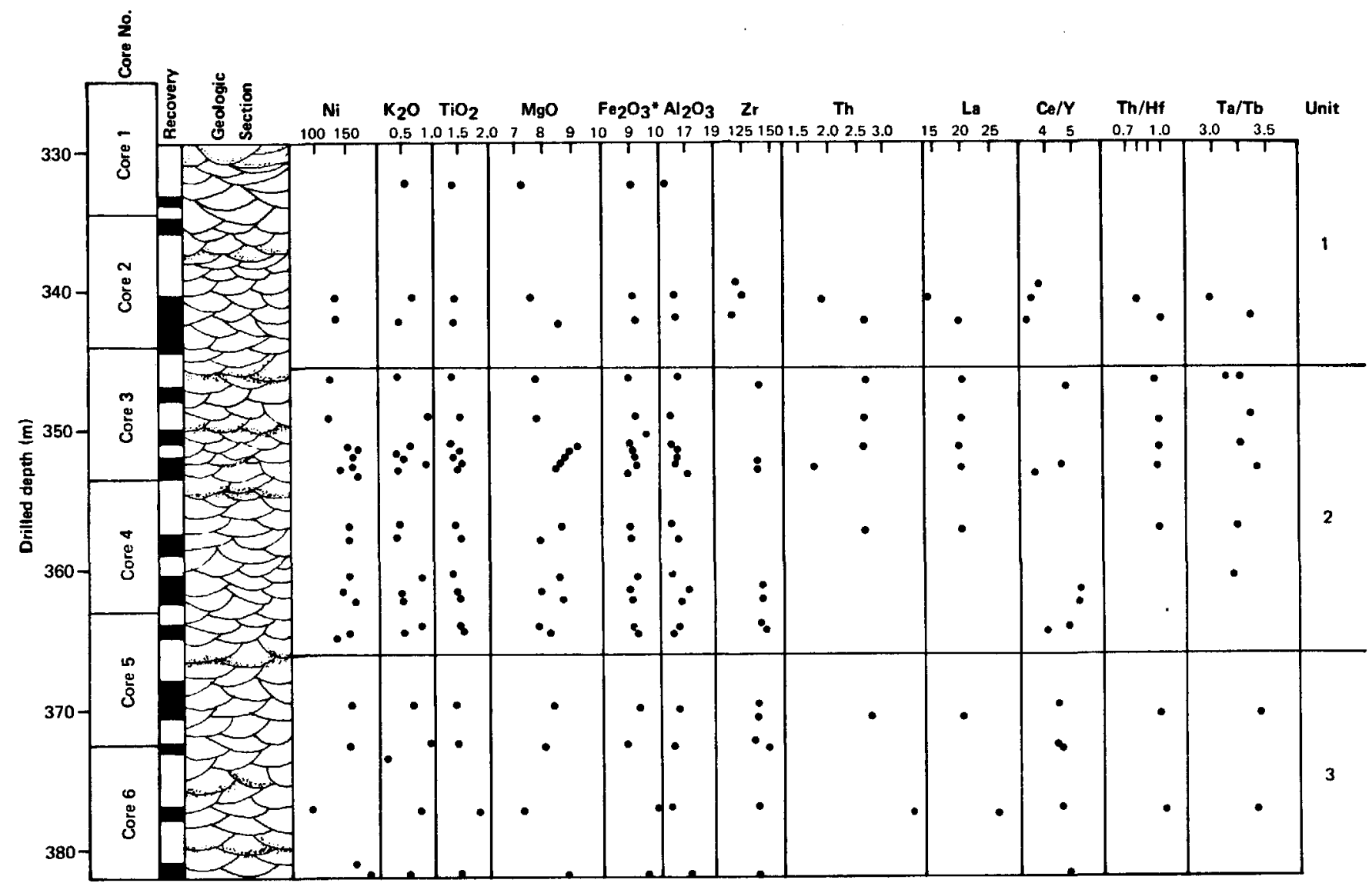

Figure 29. Detailed lithostratigraphic section of Hole 410A. See Figure 3 for source of analytical data.

TABLE 16

Representative Olivine Analyses (Hole 410A), Normalized to Four Oxygens

\begin{tabular}{|c|c|c|c|c|}
\hline $\begin{array}{c}\text { Sample } \\
\text { (Interval in } \mathrm{cm} \text { ) }\end{array}$ & $\frac{I}{I}$ & 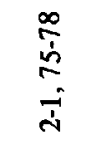 & $\begin{array}{l} \pm \\
\vdots \\
\vdots \\
\end{array}$ & 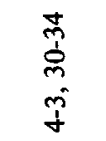 \\
\hline $\mathrm{SiO}_{2}$ & 39.99 & 40.41 & 40.48 & 40.43 \\
\hline $\mathrm{FeO}^{*}$ & 14.56 & 13.01 & 12.79 & 11.63 \\
\hline $\mathrm{MnO}$ & - & - & - & 0.22 \\
\hline $\mathrm{MgO}$ & 45.49 & 45.95 & 46.43 & 47.91 \\
\hline $\mathrm{CaO}$ & 0.36 & 0.32 & 0.23 & 0.30 \\
\hline $\mathrm{NiO}$ & - & - & 0.28 & 0.27 \\
\hline Total & 100.39 & 99.69 & 100.22 & 100.76 \\
\hline $\mathrm{Si}$ & 1.00 & 1.01 & 1.00 & 0.99 \\
\hline $\mathrm{Fe}$ & 0.30 & 0.27 & 0.27 & 0.24 \\
\hline $\mathbf{M n}$ & - & - & - & 0.01 \\
\hline $\mathbf{M g}$ & 1.69 & 1.71 & 1.72 & 1.76 \\
\hline $\mathrm{Ca}$ & 0.01 & 0.01 & 0.01 & 0.01 \\
\hline $\mathbf{N i}$ & - & - & 0.01 & 0.01 \\
\hline $\mathrm{Mg} / \mathrm{Mg}+\mathrm{Fe}^{2+} \%$ & 84.77 & 86.29 & 86.61 & 88.01 \\
\hline $\begin{array}{l}\text { Crystal } \\
\text { type }\end{array}$ & p & $\mathbf{p}$ & $\mathbf{p}$ & $\mathrm{p}$ \\
\hline
\end{tabular}

cannot be derived directly from a homogeneous mantle source by variable degrees of equilibrium partial melting. This is supported by the different shape of the chondrite-normalized REE patterns of magma types from the three areas (compare Figures 19, 32, and 43): in the $63^{\circ} \mathrm{N}$ magma types, the light REE are concave downward; in the $45^{\circ} \mathrm{N}$ magma types. the light REE are strongly concave upward and substantially enriched relative to the heavy REE; in the $37^{\circ} \mathrm{N}$ magma types (except those of Hole 413), the light REE are concave upward and may be slightly depleted or enriched relative to the heavy REE; Unit 1 of Hole 413 has REE patterns similar to the $45^{\circ} \mathrm{N}$ magma types, whereas in the HYG-element depleted basalts of Unit 2, Hole 413 , the light REE are strongly concave downward and very depleted relative to the heavy REE.

\section{PETROGENETIC PROCESSES INVOLVED IN THE PRODUCTION OF MAR BASALTS}

\section{Crystal Fractionation}

Most of the basalts recovered from $63^{\circ} \mathrm{N}$ have $\mathrm{Fe} / \mathrm{Mg}$ ratios which are too high to have been in equilibrium with a mantle containing Fo90.85. This means that the liquids from which these basalts were derived suffered significant pre-eruptional crystallization. It has been calculated, using the major-element oxides, that the most magnesian basalt in Unit 3 of Hole 407 underwent approximately 35 per cent 


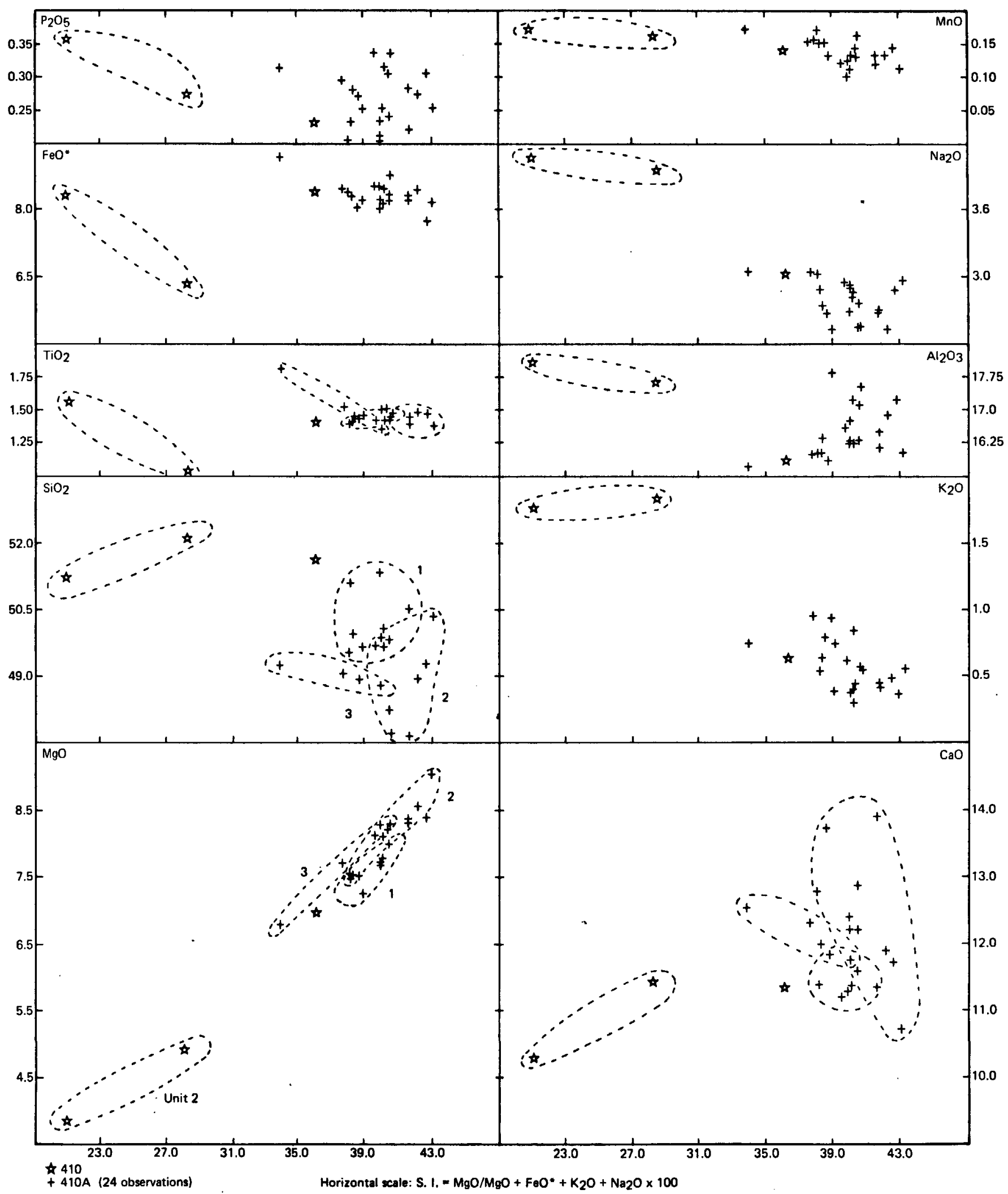

Figure 30. Variation diagram for major elements in $45^{\circ} \mathrm{N}$ holes. S.I. $=\mathrm{MgO} / \mathrm{MgO}+\mathrm{FeO}^{*}+\mathrm{Na}_{2} \mathrm{O}+\mathrm{K}_{2} \mathrm{O} \times 100$. Samples analyzed from Hole 410 are represented with crosses, samples from Hole $410 \mathrm{~A}$ with stars. Contoured units refer to lithostratigraphic units de fined in Figures 27 and 29. 


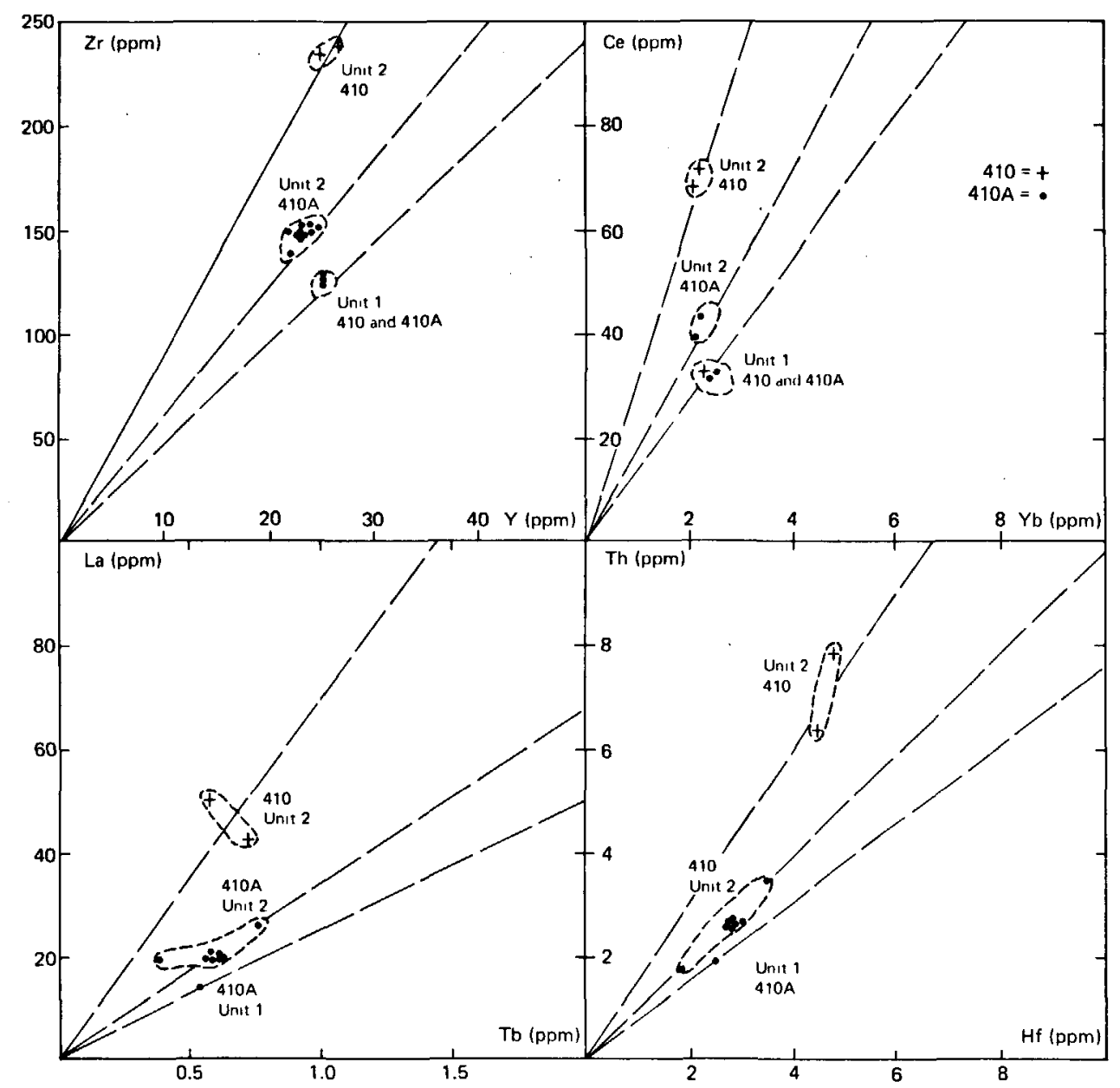

Figure 31. HYG-elements plot for IIoles 410 and 410A. See Figure 6 for source of data. Hole $410=$ crosses, Hole $410 \mathrm{~A}=$ filled circles.

crystal fractionation before eruption (Table 7), and that Unit 1 of Hole 407 may be derived from Unit 3 by a further 35 to 40 per cent crystal fractionation (Table 6). These calculations are consistent with the phenocryst assemblages and compositions observed in the basalts. The straight lines passing through the origin obtained on bi-axial plots of an HYG element versus a less incompatible element (but with a bulk D also significantly less than 1, e.g., Figure 18 ) would be predicted by the Rayleigh Law for the calculated degrees of crystal fractionation and the mineral assemblages involved (Treuil and Varet, 1973). The relative variation of the elements $\mathrm{Fe}, \mathrm{Co}, \mathrm{Ni}$, and $\mathrm{Cr}$ in the basalts of Hole 407 which can be related by crystal fractionation confirms the calculated fractionating mineral assemblage (i.e., $\mathrm{Pl} \gg \mathrm{Cpx}>\mathrm{Ol}$ ).

The presence of different crystal fractionation trends in the same hole (e.g., Holes 407 and 409 [Figures 6 and 15]) has important implications for the geodynamics of the crystal fractionation process(es) involved, i.e., the importance and nature of magma chambers along the MAR. It is clear that the different parental liquids (magma types) from which the lithostratigraphic units of one hole were derived evolved in isolation of each other prior to eruption. This implies that crystal fractionation occurred in discrete rather than continuous magma chambers which had relatively short lifespans. Closed-system crystal fractionation according to the Rayleigh Law adequately explains the post-melting evolution of the liquids, and there is no evidence to suggest that open-system magma chambers (0`Hara, 1977) have been involved in the evolution of the parental liquids.

There is also evidence for closed-system crystal fractionation in the $37^{\circ} \mathrm{N}$ basalts, although in general these basalts are much less evolved than those from other areas. Nevertheless, the cyclic evolution represented in Hole 412A is somewhat different from the crystal fractionation processes occurring at $63^{\circ} \mathrm{N}$. The major-element calculations suggest approximately 25 per cent fractionation of a mineral assemblage dominated by augite and plagioclase (Aug 6 Pl $>01$ ) (Table 25), which is in agreement with the transition-metal and HYG-element ratios. The small increase in $\mathrm{Ta} / \mathrm{Tb}$ and $\mathrm{Th} / \mathrm{Hf}$ ratios within one cycle (Figure 46) can be explained by the large proportions of augite involved in the fractionating mineral assemblage (i.e., low $\mathrm{K}_{\mathrm{T} 2 \mathrm{~Tb}}^{\mathrm{aug} \text { liq }}$ ). The presence of cycles suggests that a continuously evolving magma chamber has been sampled at different stages of its evolution. At $63^{\circ} \mathrm{N}$, each lava flow appears to be related to a separate magma chamber, since a group of flows with the same $H Y G$ ratios (i.e., a lithostratigraphic unit) and related to parental liquids 

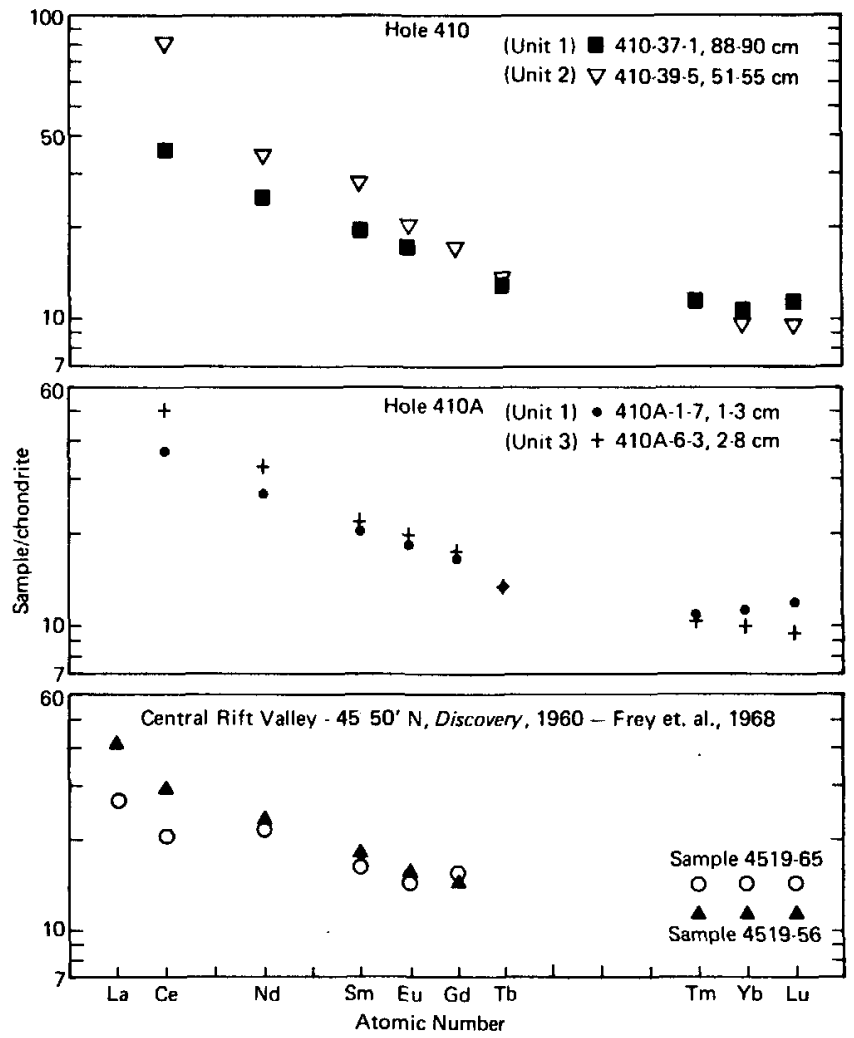

Figure 32. Masuda-Coryell plot for some basalts of $45^{\circ} \mathrm{N}$ area of the Mid-Atlantic Ridge. Chondrite values used are from Nakamura (1974). Extreme values for each hole have been reported. Data source: Wood for Leg 48 and Frey et al. (1968).

of the same composition show no systematic fractionation with time.

\section{Equilibrium Partial Melting}

It is possible to produce liquids with a significant range of values for ratios of HYG elements versus less incompatible trace elements by varying the degree of partial melting of a homogeneous source (Gast, 1968; Shaw, 1970, eq. 15). For the degrees of partial melting required to produce tholeiitic liquids (about $>5 \%$ ), this process is not capable of changing substantially a ratio of two HYG elements with similar bulk partition coefficients, nor is it capable of changing radiogenic-isotope ratios. Hence, if a suite of basalts showing a range of $\mathrm{Ta} / \mathrm{Tb}, \mathrm{Th} / \mathrm{Hf}$, etc., are related simply by equilibrium partial melting of a homogeneous mantle source, then they should have the same isotope ratios and $\mathrm{La}$ /Th (i.e., ratio of two HYG elements with similar bulk partition coefficients).

The basalts from the FAMOUS area meet these basic requirements for an equilibrium partial melting relationship. White and Bryan (1977) have shown that the different FAMOUS magma types (as defined by light/heavy REE ratios) have the same Sr-isotope ratios, and Bougault et al. (in press) have shown that the FAMOUS and Leg 37 basalts have constant $\mathrm{La} / \mathrm{Th}$ ratios. Both these studies conclude that the different magma types may be related by different

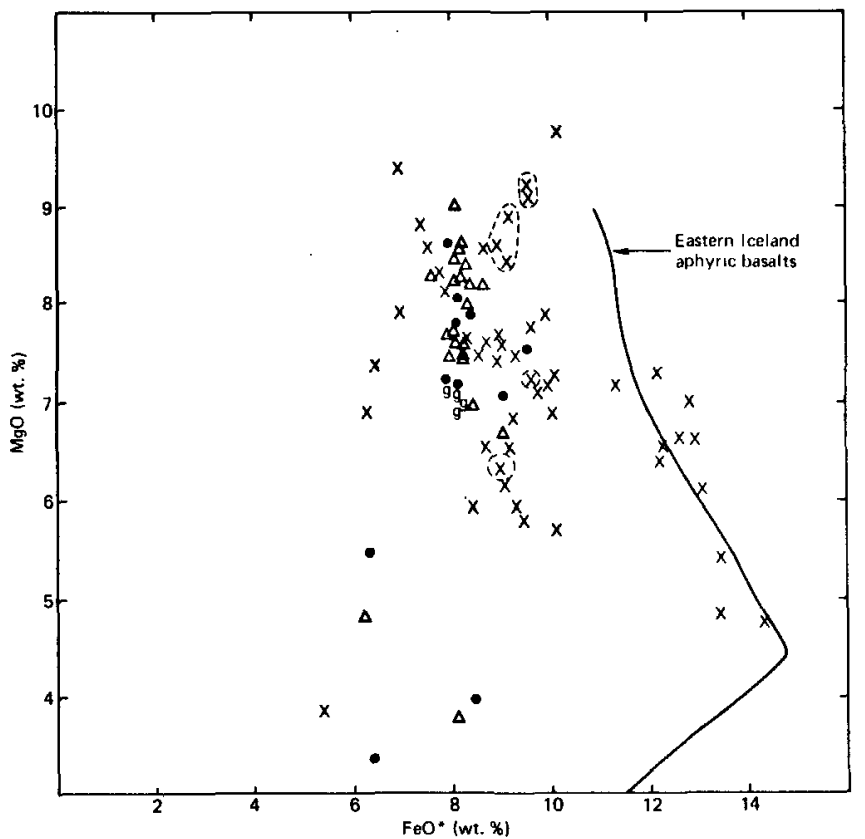

Figure 33. $\mathrm{FeO}{ }^{*}-\mathrm{MgO}$ plot for samples from Sites 410 and 410A. Filled circles: Zolotarev et al. (this volume); triangles: Bougault (this paper); (g) glassed by Wood (this paper). Samples analyzed from Leg 49 are compared with data of Aumento et al. (1971) (crosses) and Erlank and Kable (1976)(dotted contours).

degrees of equilibrium partial melting of a homogeneous mantle source. Many of the FAMOUS basalts are very $\mathrm{Mg}$-rich, and some of them represent liquids which could have been in equilibrium with the upper mantle. The small degrees of crystal fractionation involved in the production of most of these basalts makes them ideally suited for studying the partial melting processes accompanying their genesis.

The basalts drilled at $37^{\circ} \mathrm{N}$ on Leg 49 also plot close to a single straight line on the La-versus-Th plot (Figure 55[B]), and show a range of $\mathrm{Ta} / \mathrm{Tb}$ and $\mathrm{Th} / \mathrm{Hf}$ ratios (Figures 35 and $55[\mathrm{~A}]$ ). If these basalts are related by equilibrium partial melting, then Unit 1 of Hole 413 represents the smallest degrees of melting (i.e., the highest absolute abundances of HYG elemetrss and highest $\mathrm{Ta} / \mathrm{Tb}$, etc.). The basalts of Unit 2 (Hole 411) and of Holes 412 and 412A (FAMOUS magma type $B$ ) represent higher degrees of melting; the basalts of Unit 1 in Hole 411 (FAMOUS magma type A) and the MORB basalts of Unit 2 in Hole 413 represent the highest degrees of melting.

Although most of the variation in the trace-element ratios of the FAMOUS basalts can be explained by a simple batch melting process, a more detailed consideration of the chondrite-normalized REE patterns of the different magma types suggests that more complicated equilibrium partial melting processes are involved. Langmuir et al. (1977) have shown that the crossover of the chondrite-normalized REE patterns of the FAMOUS magma types cannot be explained simply by a batch melting process. This lack of correlation between the light and heavy REE of the magma types has 
D.A. WOOD ET AL.

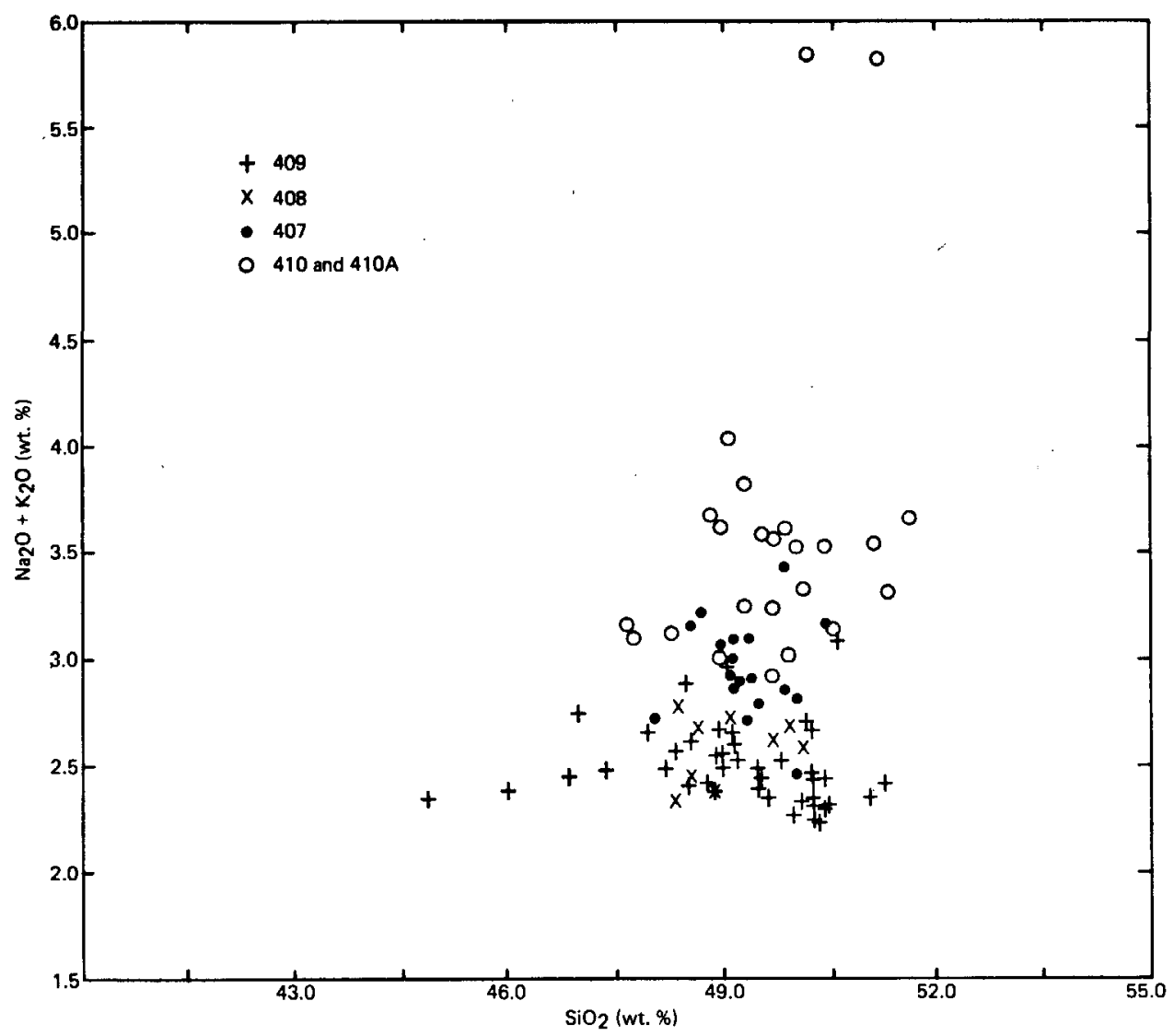

Figure 34. Alkali $\mathrm{Na}_{2} \mathrm{O}+\mathrm{K}_{2} \mathrm{O} /$ silica $\left(\mathrm{SiO}_{2}\right)$ plot for samples analyzed from $45^{\circ} \mathrm{N}$ Holes 410 and $410 \mathrm{~A}(\mathrm{O})$, compared with Reykjanes Sites 407 (•), 408 (x), and $409(+)$.

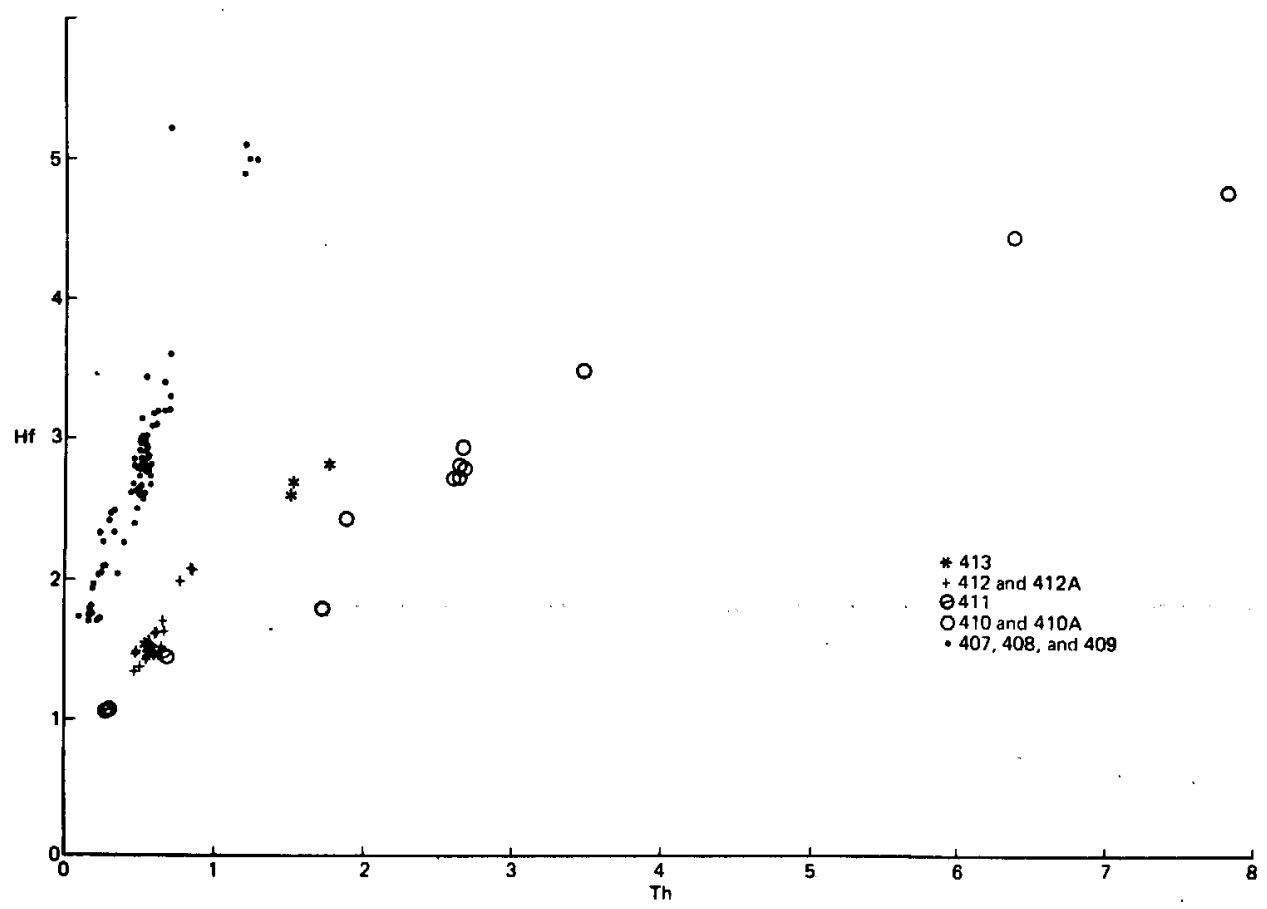

Figure 35. $\mathrm{Tb} / \mathrm{Ta}$ and (ppm) diagrams for all rocks analyzed from Leg 49: $45^{\circ} \mathrm{N}$ holes and $36^{\circ} \mathrm{N}$ holes are distinguished from $63^{\circ} \mathrm{N}$ (Reykjanes sites). 


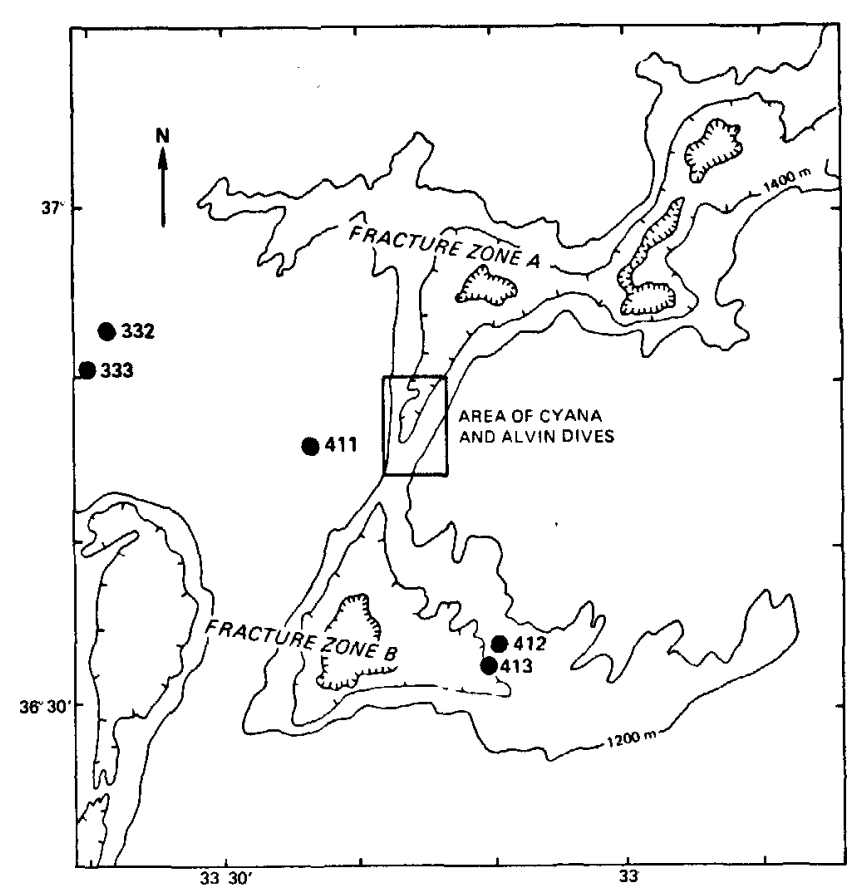

Figure 36. Simplified bathymetric map showing locations of IPOD sites in the FAMOUS area.

led them to propose a dynamic partial melting model. This involves continuous and simultaneous melting in an upwelling upper mantle beneath the rift valley over a substantial depth interval. Whereas melting is incipient at the bottom of the depth interval, the mantle source melts to a greater extent as it rises. Liquid is continuously extracted as melting proceeds (i.e., melting is incremental), but a small percentage of melt $(\simeq 5 \%)$ always remains in equilibrium with the residue. This process differs from incremental melting by the batch-melting equation or fractional fusion (Shaw, 1970, eq. 13), in that the small amount of melt which remains in equilibrium with the residue throughout melting prevents the absolute abundances of the HYG elements from decreasing rapidly, and decreases the HYG-element/less incompatible trace-element ratios in the residue as melting proceeds. The effect of this process on the HYG-element/less incompatible trace-element ratios is variable, depending on the proportions of melt and solid phases that constitute the source; as well as on the solid/liquid bulk partition coefficients of the ratio and the degree of melting, which control other equilibrium partial melting processes. Langmuir et al. (1977) have shown that this process is capable of producing liquids with chondrite-normalized REE patterns which cross over from a homogeneous mantle source. It is therefore a more realistic model than batch melting for the origin of the FAMOUS magma types.

The more refractory major-element composition (higher $\mathrm{Mg} / \mathrm{Fe}$ and $\mathrm{Ca} / \mathrm{Al}$ ) of $\mathrm{FAMOUS}$ magma type $\mathrm{A}$ relative to m.'yma type $B$ is consistent with a model adducing incremental melting in which magma type $B$ is derived at an

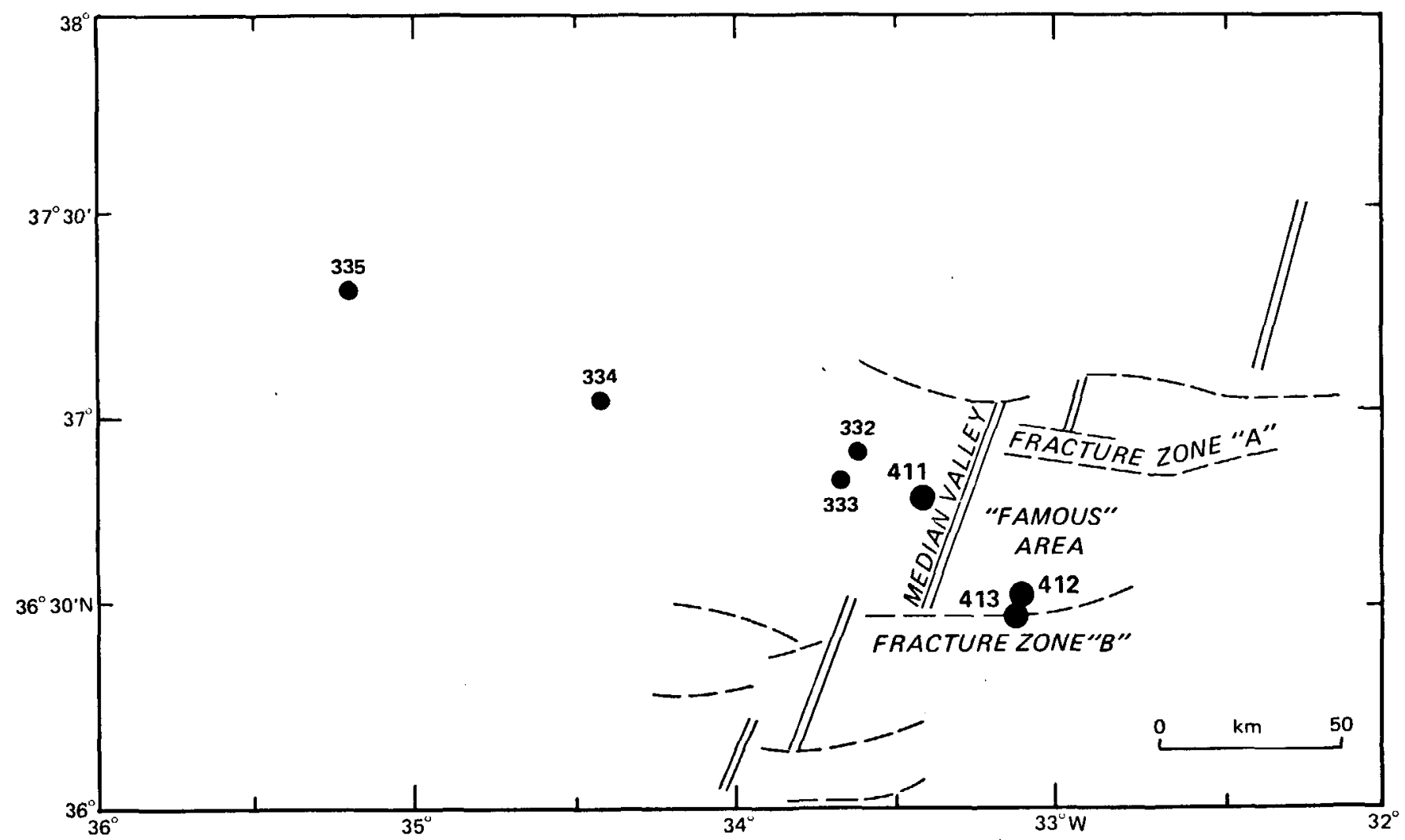

Figure 37. Map showing the location of the IPOD transect in the $36^{\circ} 30-37^{\circ} 30 \mathrm{~N}$ area, and in particular the locations of Leg 49 sites with respect to Leg 37 and 38 sites. 


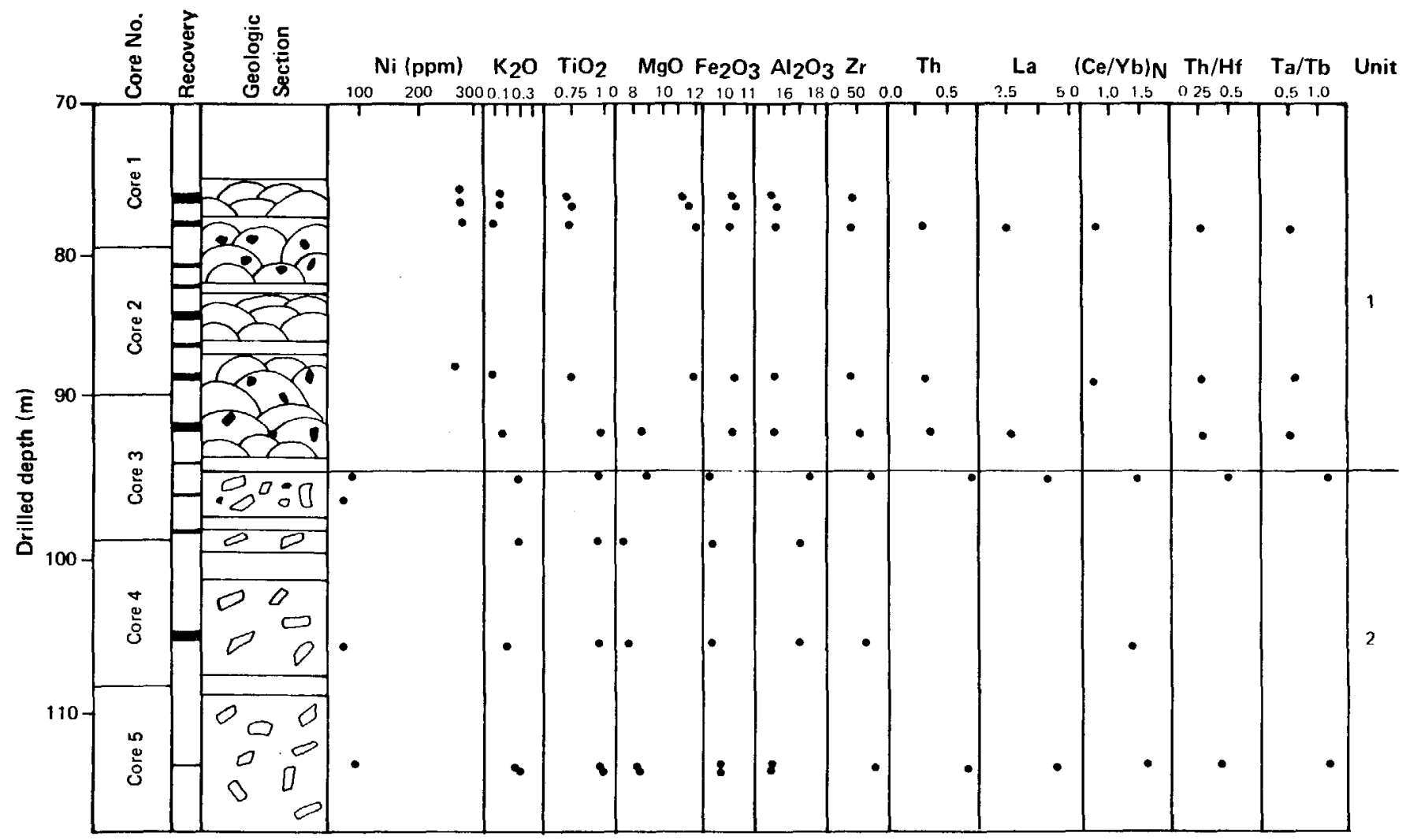

Figure 38. Detailed lithostratigraphic section for Hole 411. See Figure 3 for source of analytical data.

TABLE 17

Representative Olivine Analyses (Hole 411), Normalized to Four Oxygens

\begin{tabular}{|c|c|c|c|c|c|c|c|}
\hline $\begin{array}{c}\text { Sample } \\
\text { (Interyal in com) }\end{array}$ & 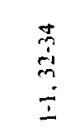 & $\begin{array}{l}\frac{3}{i} \\
\vec{i} \\
\vec{i}\end{array}$ & $\begin{array}{l}m \\
\vec{i} \\
i \\
i \\
i\end{array}$ & $\begin{array}{l}\frac{a}{9} \\
\frac{6}{6} \\
\frac{1}{m}\end{array}$ & 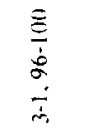 & $\begin{array}{l}\frac{1}{1} \\
\dot{5} \\
\frac{1}{4}\end{array}$ & $\begin{array}{l}\vec{T} \\
\vec{n} \\
\dot{\vec{n}} \\
\dot{\vec{n}}\end{array}$ \\
\hline $\mathrm{SiO}_{2}$ & 40.51 & 40.20 & 40.13 & 40.18 & 39.62 & 39.84 & 41.12 \\
\hline $1.00^{*}$ & 11.20 & 12.06 & 13.16 & 11.55 & 14.90 & 14.44 & 8.84 \\
\hline $\mathrm{MnO}$ & & 0.20 & 0.23 & & & 0.32 & 1136 \\
\hline $\mathrm{M}_{2} \mathrm{O}$ & 47.59 & 46.73 & 45.59 & 47.35 & 45.54 & 44.48 & 48.90 \\
\hline $\mathrm{CaO}$ & 0.33 & 0.27 & 0.31 & 0.35 & 0.38 & 0.39 & 0.26 \\
\hline $\mathrm{N}_{1} \mathrm{O}$ & 0.26 & 0.31 & 0.31 & 0.37 & - & & 0.24 \\
\hline Total & 99.92 & 99.85 & 100.13 & 99.70 & 100.44 & 99.47 & 99.37 \\
\hline $\mathrm{Si}$ & 1.00 & 1.00 & 1.00 & 1.00 & 0.99 & 1.00 & 1.01 \\
\hline lic & 0.23 & 0.25 & 0.27 & 0.24 & 0.31 & 0.30 & 0.18 \\
\hline Mn & & 0.00 & 0.01 & & & 0.01 & 0.01 \\
\hline $\mathrm{Mg}$ & 1.75 & 1.73 & 1.71 & 1.75 & 1.70 & 1.67 & 1.79 \\
\hline $\mathrm{Ca}$ & 0.01 & 0.01 & 0.01 & 0.01 & 0.01 & 0.01 & 0.01 \\
\hline $\mathrm{Ni}$ & 0.01 & 0.01 & 0.01 & 0.01 & - & - & 0.01 \\
\hline $\mathrm{Mg} / \mathrm{Mg}+\mathrm{Ii} \mathrm{e}^{2+1 / n}$ & 88.33 & 87.33 & 86.19 & 87.97 & 84.49 & 84.59 & 90.79 \\
\hline $\begin{array}{l}\text { Crystal } \\
\text { type }\end{array}$ & $p$ & זnp & g & p & $\mathrm{mp}$ & $\mathrm{mp}$ & mega $p$ \\
\hline
\end{tabular}

earlier stage of the melting event than magma type $A$. The high $\mathrm{Mg} / \mathrm{Fe}$ of the olivines and chrome spinels in magma type A support this conclusion.

It is more difficult to study the petrogenetic relationships between the magma types recovered from $45^{\circ} \mathrm{N}$ than those from $37^{\circ} \mathrm{N}$, because they are all relatively evolved and have
TABLE 18

Representative Magnesiochromites From Unit 1, Hole 411, Normalized to 32 Oxygens $\left(\mathrm{Fe}^{2+}\right.$ and $\mathrm{Fe}^{3+}$ estimated from stoichiometry)

\begin{tabular}{|c|c|c|c|c|c|c|c|}
\hline $\begin{array}{c}\text { Sample } \\
\text { (Interval in a (II) }\end{array}$ & $\begin{array}{l}\underset{m}{+} \\
\stackrel{2}{m} \\
\stackrel{-}{\Sigma}\end{array}$ & 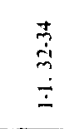 & $\begin{array}{l}\vec{J} \\
\stackrel{1}{m} \\
\stackrel{-}{ \pm}\end{array}$ & $\begin{array}{l}\stackrel{\rho}{\dot{b}} \\
\dot{\Delta} \\
\dot{\vec{m}}\end{array}$ & 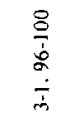 & $\frac{g}{\frac{g}{\dot{b}}} \frac{\dot{m}}{\dot{m}}$ & $\begin{array}{l}\frac{8}{0} \\
\dot{0} \\
\dot{5} \\
\dot{m}\end{array}$ \\
\hline $\begin{array}{l}\mathrm{S}_{1} \mathrm{O}_{2} \\
\mathrm{TiO}_{2}\end{array}$ & $\begin{array}{l}0.52 \\
0.21\end{array}$ & & 0.41 & 0.28 & 0.45 & 0.61 & 0.69 \\
\hline $\mathrm{N}_{2} \mathrm{O}_{3}$ & 1122 & 3184 & 32111 & 3136 & 3202 & 3275 & 3256 \\
\hline $\mathrm{Cr}_{2} \mathrm{O}_{3}$ & 33.57 & 34.114 & 3350 & 33.92 & 33.65 & 33.92 & 3285 \\
\hline $\mathrm{r}_{2} \mathrm{O}_{3}$ & 6.86 & 5.74 & 5.64 & 477 & 4.51 & 352 & 4.88 \\
\hline 100 & 958 & 11.32 & 11.111 & 13.41 & 12.67 & 12.56 & 12.51 \\
\hline $\mathrm{MnO}$ & 1144 & 0.51 & 032 & 044 & & 0.41 & 0.45 \\
\hline$M_{1} O$ & 1673 & 16.43 & 1639 & 14.78 & 15.92 & 15.66 & 15.47 \\
\hline $\operatorname{cis}(0)$ & 0.32 & & 0.27 & & & & \\
\hline $\mathrm{N}^{\mathrm{OO}}$ & 0.27 & & & & $\therefore$ & & \\
\hline Tot,ul & 99.72 & 99.88 & 99.73 & 9896 & 99.22 & 99.78 & 9941 \\
\hline $\begin{array}{l}\mathrm{Si} \\
\mathrm{Ti}\end{array}$ & $\begin{array}{l}\text { () } 118 \\
0.039\end{array}$ & & 0.099 & 0.069 & 0.109 & 0.139 & 0.158 \\
\hline A & 8.544 & 8.732 & 8.805 & 8.752 & 8825 & 8.957 & 8941 \\
\hline $\mathrm{Cr}_{\mathrm{r}} \mathrm{C}$ & 6.157 & 6.261 & 6.169 & 6. 344 & 6219 & 6.222 & 6.049 \\
\hline $1 \mathrm{c}^{3+}$ & 1.198 & 1.004 & 0.987 & 0.849 & (1) 792 & 0.614 & 0857 \\
\hline $10^{2+}$ & 1.865 & 2.203 & 2.161 & 2.655 & 2.477 & 2.438 & 2.438 \\
\hline $\mathrm{Mn}_{\mathrm{n}}$ & 0.1888 & 0.098 & 0.059 & 0.089 & & 0079 & 0.089 \\
\hline$M_{z}$ & 5794 & 5.700 & 5.686 & 5.210 & 5.548 & 5.410 & 5.369 \\
\hline co & 0.1859 & & & & & & \\
\hline $\mathrm{Ni}$ & 0.049 & & & & & & \\
\hline$M_{p} / M_{n}+1 \cdot c^{2+}$ & 0.756 & 0.721 & 0.725 & 0.662 & 0.691 & 0.689 & 0688 \\
\hline$C r / C r+M$ & 0.419 & 0418 & 0.412 & 0420 & 0.413 & 0.410 & 0404 \\
\hline $\mathrm{He}^{3+} / \mathrm{Cc}^{3+}+\mathrm{Cr}+\mathrm{Al}$ & 0.075 & 0.063 & 0.062 & 0.053 & 0.050 & 0.039 & 0.054 \\
\hline $\begin{array}{l}\mathrm{M}_{\mathrm{q} / \mathrm{M}}+\mathrm{l} \cdot \mathrm{c}^{2+} \\
\text { of howt ol }\end{array}$ & 0.883 & 0.881 & 0.888 & 0.880 & 0.880 & 0.880 & 0.880 \\
\hline
\end{tabular}



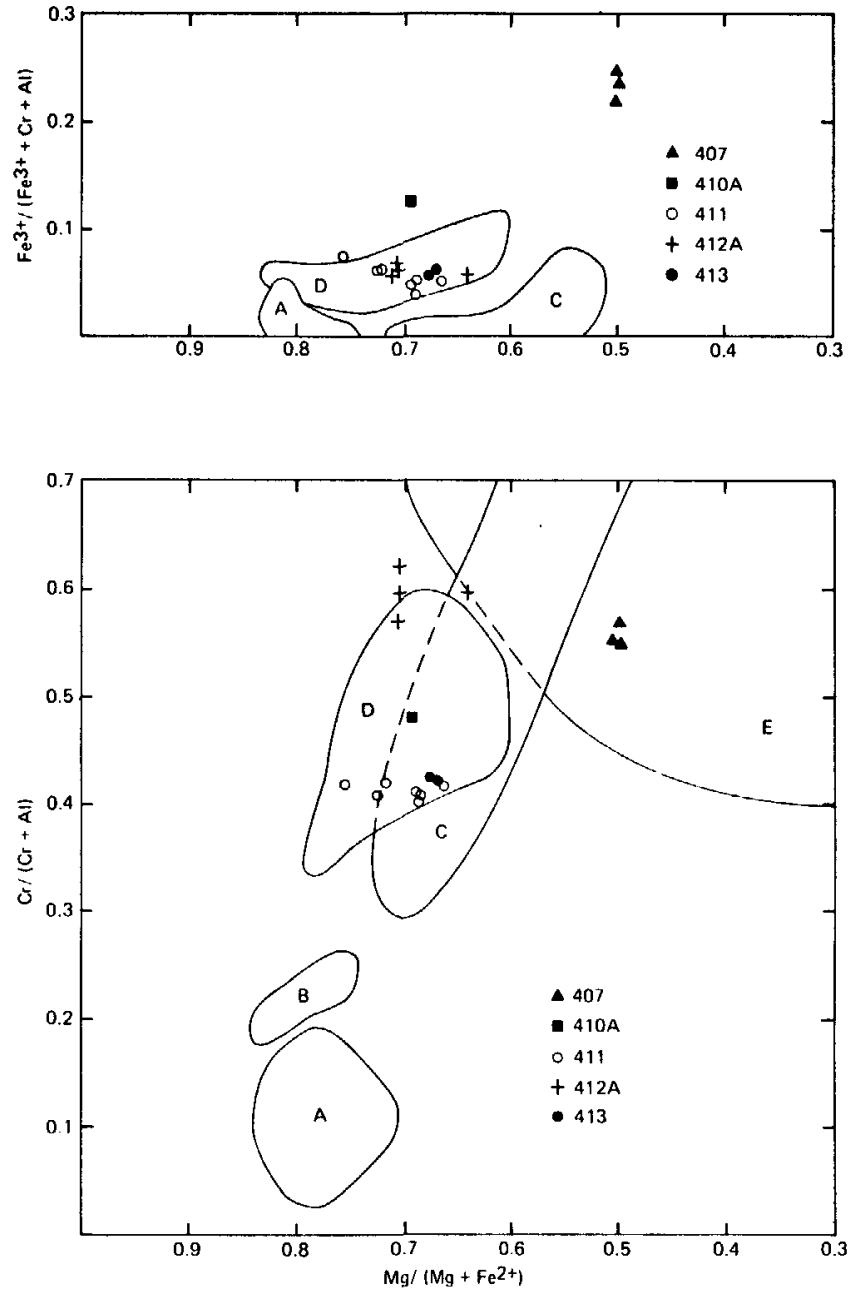

Figure 39. Plot of the composition of spinels analyzed from Leg 49 basalts, compared with spinels from other environments. (A) lherzolites; (B) chromian spinel in basalts dredged from $M A R$ between $29^{\circ} \mathrm{N}$ and $40^{\circ} \mathrm{N}$, from IPOD Leg 37; (C) alpine peridotites; (D) magnesio-chromites in basalts dredged from the MAR between $29^{\circ} \mathrm{N}$ and $40^{\circ} \mathrm{N}$ and from IPOD Leg 37; (E) layered intrusion (Irvine, 1967; Jackson, 1969).

undergone significant pre-eruption crystallization. Notwithstanding this, the alkali-element-enriched basalts from Holes 410 and $410 \mathrm{~A}$ plot on a line with a slightly higher $\mathrm{Th} / \mathrm{La}$ ratio than the $37^{\circ} \mathrm{N}$ basalts (Figure 55[B]). The mugearites in Unit 2 of Hole 410 have higher Th/La than the basalts of this site (Figure 55[B]). The very low concentrations of the heavy REE and the high but variable light/heavy REE ratios of these rocks (Figure 32) suggest that they may be related by different degrees of equilibrium partial melting of a homogeneous, gamet-bearing mantle source $\left(K_{\mathrm{Ce} / \mathrm{Yb}}^{\mathrm{pt} l \mathrm{ld}} \ll 1\right)$ (Shimizu and Kushiro, 1975). The slightly higher Th/La ratios of the mugearites, compared with the basalts, may be a consequence of the small degrees of partial melting $(\simeq 5 \%)$ involved in generating the parental alkali basalt liquid from which these evolved compositions have subsequently been derived. The preliminary results of
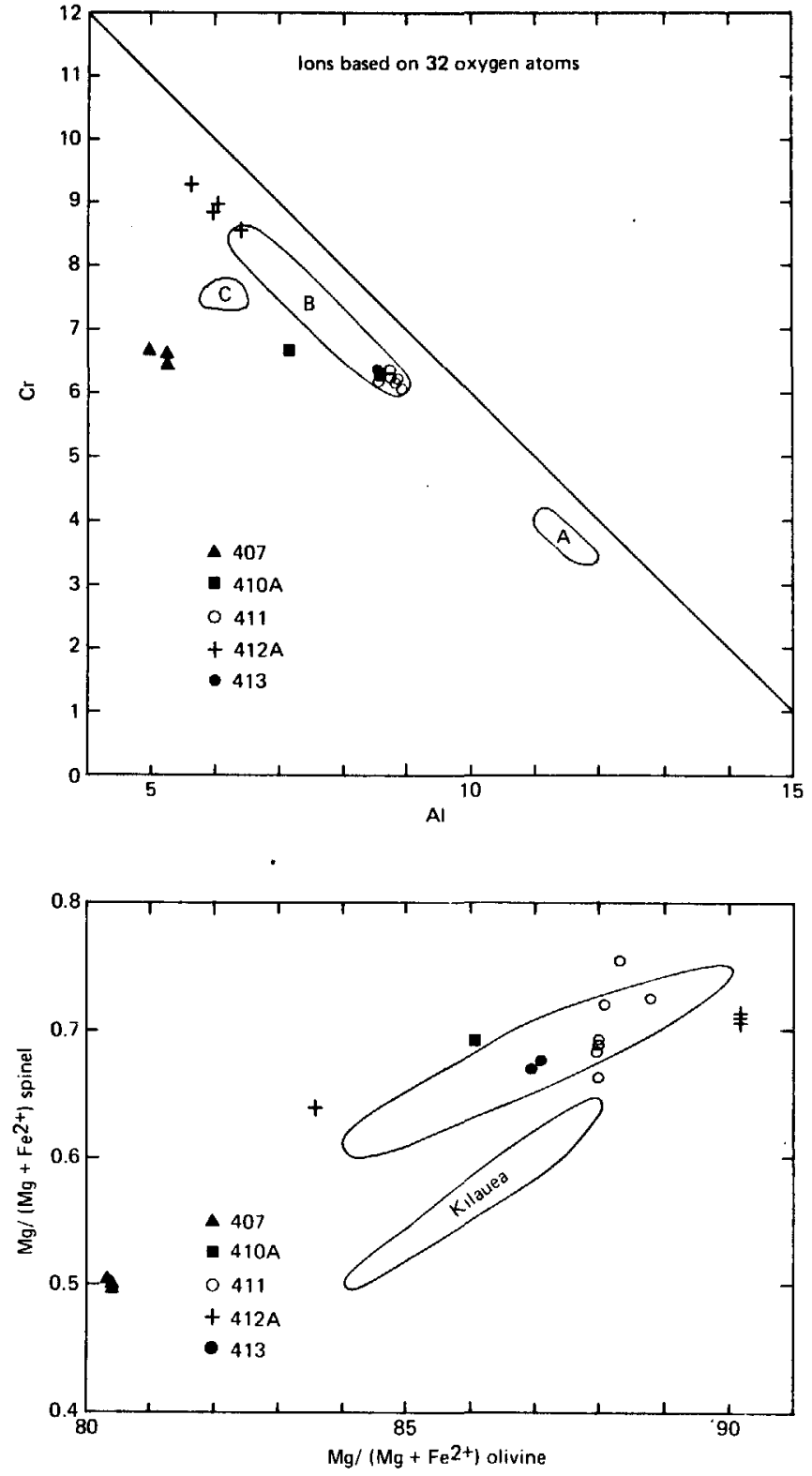

Figure 40. Plot of the composition of spinels analvzed from Leg 49 basalts, compared with spinels from other environments. Data from Kilauea are taken from Evans and Wright (1972).

solid/liquid partition coefficient determinations for the elements La, Ta, and Th (Joron, in preparation) suggest that La and Ta have similar partition coefficients, but that Th has partition coefficients systematically lower than the other two, no matter what the mineral. The lower bulk $K_{D}$ for $T h$ than for La would result in variable $\mathrm{Th} / \mathrm{La}$ ratios in liquids produced by small but variable degrees of partial melting the liquids generated by the smallest degrees of melting would have the highest Th/La. A detailed isotopic study of the different $45^{\circ} \mathrm{N}$ magma types is necessary before a model adducing equilibrium partial melting of a homogeneous mantle source can be confirmed. 
TABLE 19

Representative Plagioclase Analyses (Hole 411), Normalized to Eight Oxygens

\begin{tabular}{|c|c|c|c|c|c|c|c|}
\hline $\begin{array}{c}\text { Sample } \\
\text { (Interval in } \mathrm{cm} \text { ) }\end{array}$ & $\begin{array}{l}m \\
\dot{r} \\
\tilde{y} \\
\tilde{n}\end{array}$ & $\begin{array}{l}m \\
\dot{\sim} \\
\dot{\sim} \\
\dot{\sim}\end{array}$ & $\begin{array}{l}\frac{8}{0} \\
\dot{b} \\
\stackrel{2}{\dot{m}}\end{array}$ & $\begin{array}{l}\stackrel{0}{m} \\
\dot{m} \\
\dot{m} \\
\dot{m}\end{array}$ & $\begin{array}{l}2 \\
\frac{1}{0} \\
\frac{1}{j}\end{array}$ & $\begin{array}{l}0 \\
\stackrel{0}{0} \\
8 \\
0 \\
\dot{\dot{d}}\end{array}$ & $\begin{array}{l}\stackrel{d}{d} \\
\stackrel{\sim}{\Delta} \\
\dot{n}\end{array}$ \\
\hline $\mathrm{SiO}_{2}$ & 50.24 & 49.58 & 48.86 & 46.22 & 46.71 & 50.70 & 50.79 \\
\hline $\mathrm{Al}_{2} \mathrm{O}_{3}$ & 30.53 & 31.72 & 32.30 & 33.74 & 33.53 & 31.53 & 30.52 \\
\hline $100^{*}$ & 0.84 & 0.59 & 0.37 & 0.40 & 0.41 & 0.43 & 0.32 \\
\hline $\mathrm{CaO}$ & 15.35 & 16.04 & 15.81 & 17.89 & 18.01 & 15.83 & 15.18 \\
\hline $\mathrm{N}_{\mathrm{a}_{2}} \mathrm{O}$ & 2.78 & 2.44 & 1.82 & 1.22 & 0.89 & 2.38 & 2.40 \\
\hline $\mathrm{K}_{2} \mathrm{O}$ & 0.07 & 0.08 & & & & & \\
\hline Total & 99.81 & 100.45 & 99.16 & 99.47 & 99.55 & 100.87 & 99.22 \\
\hline $\mathbf{S i}$ & 2.30 & 2.26 & 2.25 & 2.14 & 2.16 & 2.29 & 2.33 \\
\hline Al & 1.65 & 1.70 & 1.75 & 1.84 & 1.83 & 1.68 & 1.65 \\
\hline $\mathrm{re}$ & 0.03 & 0.02 & 0.01 & 0.02 & 0.02 & 0.02 & 0.01 \\
\hline $\mathrm{Cu}$ & 0.75 & 0.78 & 0.78 & 0.89 & 0.89 & 0.77 & 0.75 \\
\hline $\mathrm{Na}$ & 0.25 & 0.22 & 0.16 & 0.11 & 0.08 & 0.21 & 0.21 \\
\hline $\mathrm{K}$ & 0.00 & 0.01 & & & & & \\
\hline An & 75.01 & 78.06 & 82.76 & 89.02 & 91.82 & 78.61 & 77.75 \\
\hline $\mathrm{Ab}$ & 24.58 & 21.48 & 17.24 & 10.98 & 8.18 & 21.39 & 22.25 \\
\hline $\mathrm{O}_{\mathrm{r}}$ & 0.41 & 0.46 & & & & & \\
\hline $\begin{array}{l}\text { Crystial } \\
\text { type }\end{array}$ & g & mp & $m p$ & megu p & mega p & $\mathrm{mp}$ & $m p$ \\
\hline
\end{tabular}

\section{Melting of Heterogeneous Mantle Sources}

The magma types recovered from $63^{\circ} \mathrm{N}$ during Leg 49 , and from Iceland and the surrounding ocean floor by previous studies, show a range of $\mathrm{Th} / \mathrm{La}$ and ${ }^{87} \mathrm{Sr} /{ }^{86} \mathrm{Sr}$ ratios (Figures 55B and 23), as well as a large range in HYG-element/less incompatible trace-element ratios (Figure 18). These magma types cannot therefore be related by equilibrium partial melting of a homogeneous mantle. The petrogenesis of these magma types has been extensively discussed in recent publications, and remains controversial. O'Nions et al. (1976) have used the correlation between $(\mathrm{Ce} / \mathrm{Yb})_{\mathrm{N}}$ and ${ }^{87} \mathrm{Sr} /{ }^{86} \mathrm{Sr}$ ratios in some Iceland and Reykjanes Ridge tholeiites as evidence for heterogeneities in the upper mantle source. If they are correct in this, then the correlation between HYG-element/less incompatible trace-element and ${ }^{87} \mathrm{Sr} /{ }^{86} \mathrm{Sr}$ ratios restricts the possible variation in the degree of partial melting involved in producing these magma types. Wide variation in the degree of partial melting of the different mantle sources would not produce magma types with a correlation between these ratios, unless the degree of melting varied systematically with the isotopic composition of the sources (a seemingly fortuitous possibility).

The correlations between HYG-element concentrations and $\mathrm{Sr}$ isotopes in the magma types also suggest that the fractionation events responsible for the heterogeneities in the source must have occurred at a similar time; i.e., the variation in $\mathrm{Rb} / \mathrm{Sr}$ was produced in the source at the same time as the $\mathrm{Ce} / \mathrm{Yb}$ variation. The $\mathrm{Rb}-\mathrm{Sr}$ systematics require that this mantle fractionation event occurred at least 200 m.y. ago, in order to produce the observed range of ${ }^{87} \mathrm{Sr} /{ }^{86} \mathrm{Sr}$ ratios. Variations in $\mathrm{Pb}$-isotope ratios (cf. Mattinson and Daly, this volume) place further constraints on the age of the fractionation event, and suggest that it was substantially older than 200 m.y. (Sun and Hanson, 1975).
TABLE 20

Representative Clinopyroxene

Analyses, Unit 2 (Hole 411),

Normalized to Six Oxygens

\begin{tabular}{|c|c|c|}
\hline $\begin{array}{c}\text { Sample } \\
\text { (Interval in } \mathrm{cm} \text { ) }\end{array}$ & $\begin{array}{l}\stackrel{0}{j} \\
\dot{j} \\
\dot{j}\end{array}$ & $\begin{array}{l}\vec{i} \\
\dot{\sim} \\
\dot{\vec{n}}\end{array}$ \\
\hline $\mathrm{SiO}_{2}$ & 54.76 & 52.11 \\
\hline $\mathrm{Al}_{2} \mathrm{O}_{3}$ & 0.77 & 3.72 \\
\hline $\mathrm{FeO}^{*}$ & 6.05 & 5.52 \\
\hline $\mathrm{MgO}$ & 18.92 & 17.20 \\
\hline $\mathrm{CaO}$ & 19.02 & 19.73 \\
\hline $\mathrm{TiO}_{2}$ & - & 0.43 \\
\hline $\mathrm{Cr}_{2} \mathrm{O}_{3}$ & 0.33 & 0.4 \\
\hline Total & 99.85 & 99.1 \\
\hline Si & 1.99 & 1.91 \\
\hline $\mathrm{Al}^{\mathrm{IV}}$ & 0.01 & 0.09 \\
\hline $\mathrm{Al}^{\mathrm{VI}}$ & 0.02 & 0.07 \\
\hline $\mathrm{Fe}$ & 0.18 & 0.17 \\
\hline $\mathbf{M g}$ & 1.03 & 0.9 \\
\hline $\mathrm{Ca}$ & 0.74 & 0.78 \\
\hline $\mathrm{Ti}$ & - & 0.01 \\
\hline $\mathrm{Cr}$ & 0.01 & 0.01 \\
\hline $\mathrm{Mg} / \mathrm{Mg}+\mathrm{Fe}^{2+} \%$ & 84.79 & 84.75 \\
\hline Wo & 37.99 & 41.14 \\
\hline En & 52.58 & 49.88 \\
\hline Fs & 9.43 & 8.98 \\
\hline $\begin{array}{l}\text { Crystal } \\
\text { type }\end{array}$ & $\mathrm{mp}$ & $\mathbf{p}$ \\
\hline
\end{tabular}

Other Models Adduced to Explain the Petrogenesis of the Iceland and Reykjanes Ridge Magma Types

An alternative to supposing a multiplicity of mantle sources of different isotopic and HYG-element composition has been to argue for two mantle sources of extreme compositions which mix directly, or melts derived from them mix, in varying proportions, resulting in a range of magma types intermediate in composition between the two primary mantle sources (Schilling, 1973). Magma types produced by mixing of two end-member compositions should lie on straight lines on all element-element biaxial plots that do not necessarily pass through the origin. On biaxial plots of element ratio versus element, or element ratio versus element ratio, mixing does not necessarily produce straight-line relationships. It is apparent from such diagrams that the total range of basalt compositions occurring in the Iceland and Reykjanes Ridge area cannot be explained by mixing of two end-member sources or melts (Treuil and Varet, 1973; O'Nions et al., 1976; Langmuir et al., in press), as originally suggested by Schilling (1973).

Considering only the basalts recovered from $63^{\circ} \mathrm{N}$ during Leg 49 , it is apparent that they lie along straight lines on major- and trace-element biaxial plots, as well as on plots of element ratio versus isotope ratio (Figures 18, 20, 21, 22, and 23). It may therefore be possible to explain the $63^{\circ} \mathrm{N}$ data alone in terms of a mixing model, but the inability of this model to explain all the chemical variation in the basalts 


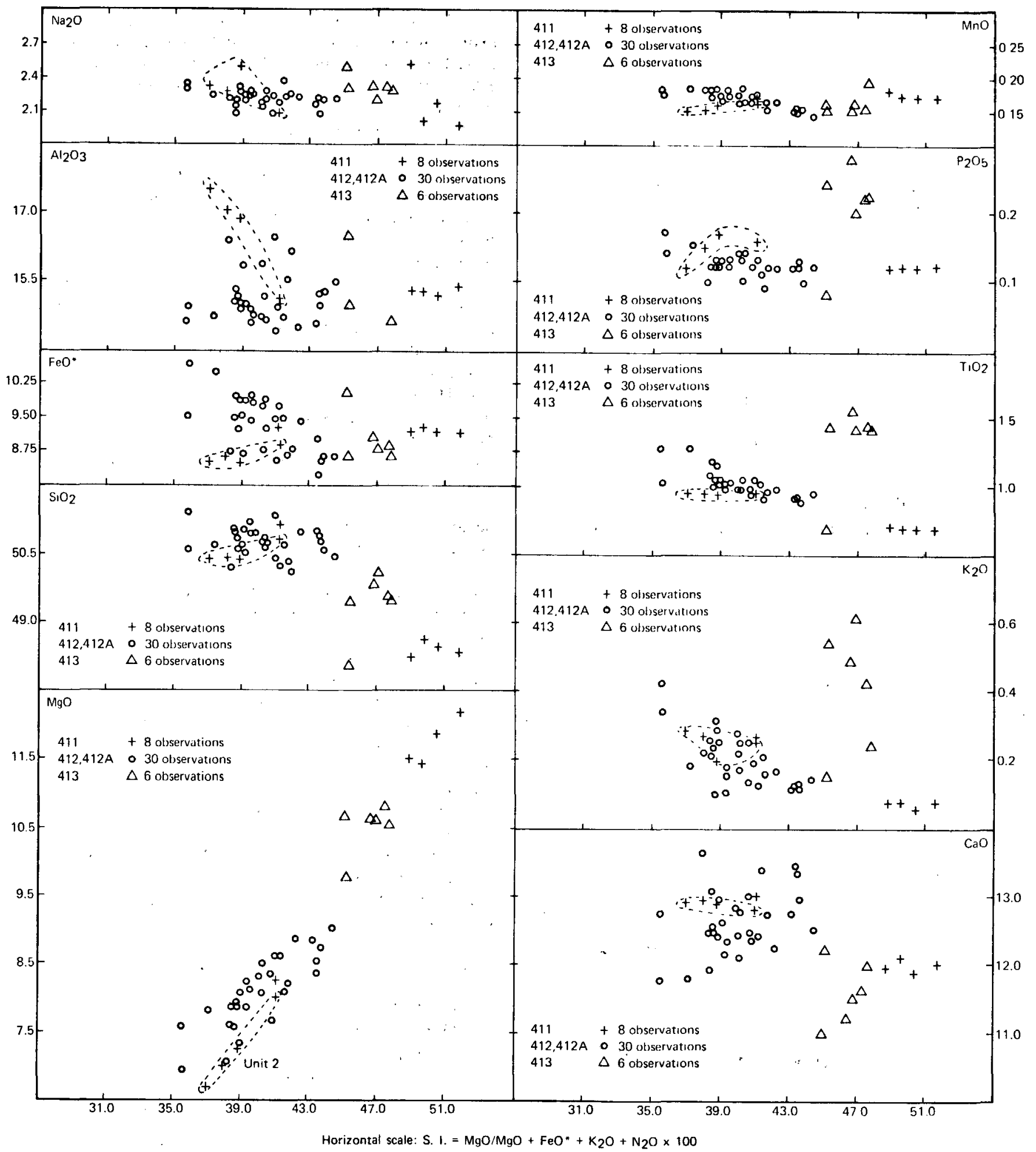

Figure 41. Variation diagram for major elements in $37^{\circ} \mathrm{N}$ sites. S.I. $=\mathrm{MgO} / \mathrm{MgO}+\mathrm{FeO}^{*}+\mathrm{Na}_{2} \mathrm{O}+\mathrm{K}_{2} \mathrm{O} \times 100$. Hole $411(\Delta)$, Hole 412 (O), Hole $413(+)$.

of the Iceland and Reykjanes Ridge area makes it an unfavorable alternative to the heterogeneous mantle model described above. Also, as discussed earlier, the mantle plume hypothesis, as proposed by Vogt (1972) and developed using the mixing hypothesis by Schilling (1973), is incapable of explaining the temporal variations in chemistry of the basalts generated at the $63^{\circ} \mathrm{N}$ segment of the Reykjanes Ridge.

Several other models have been proposed to explain some or all of the trace-element and isotope variations observed in 


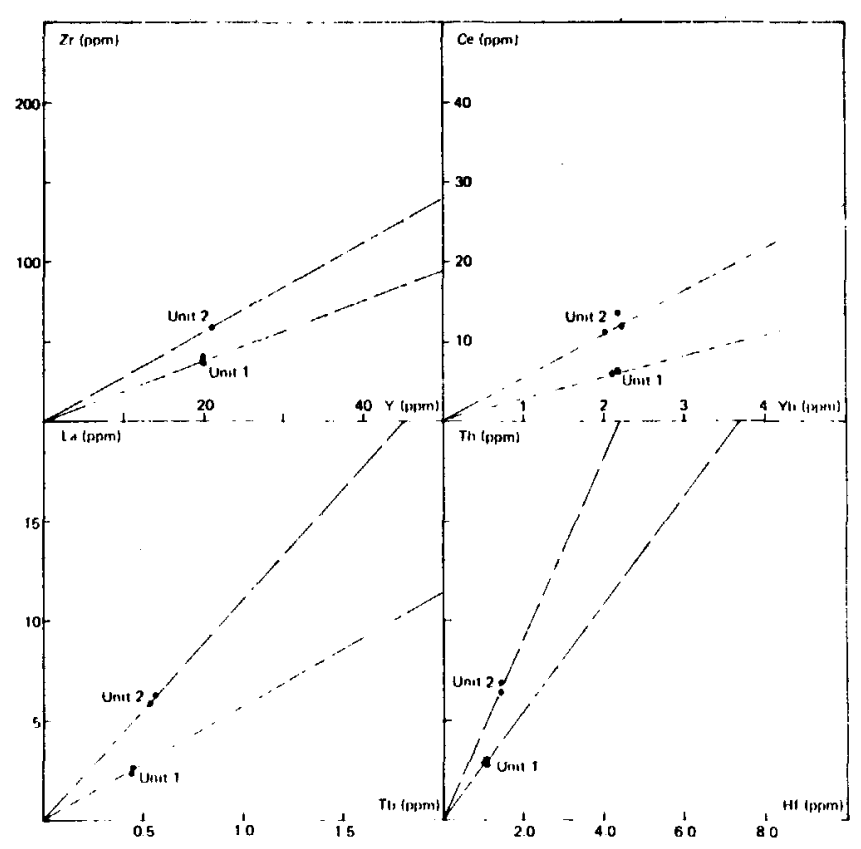

Figure 42. HYG-element plots for Hole 411 basalts. See Figure 6 for source of data. Units 1 and 2 are clearly distinguished.
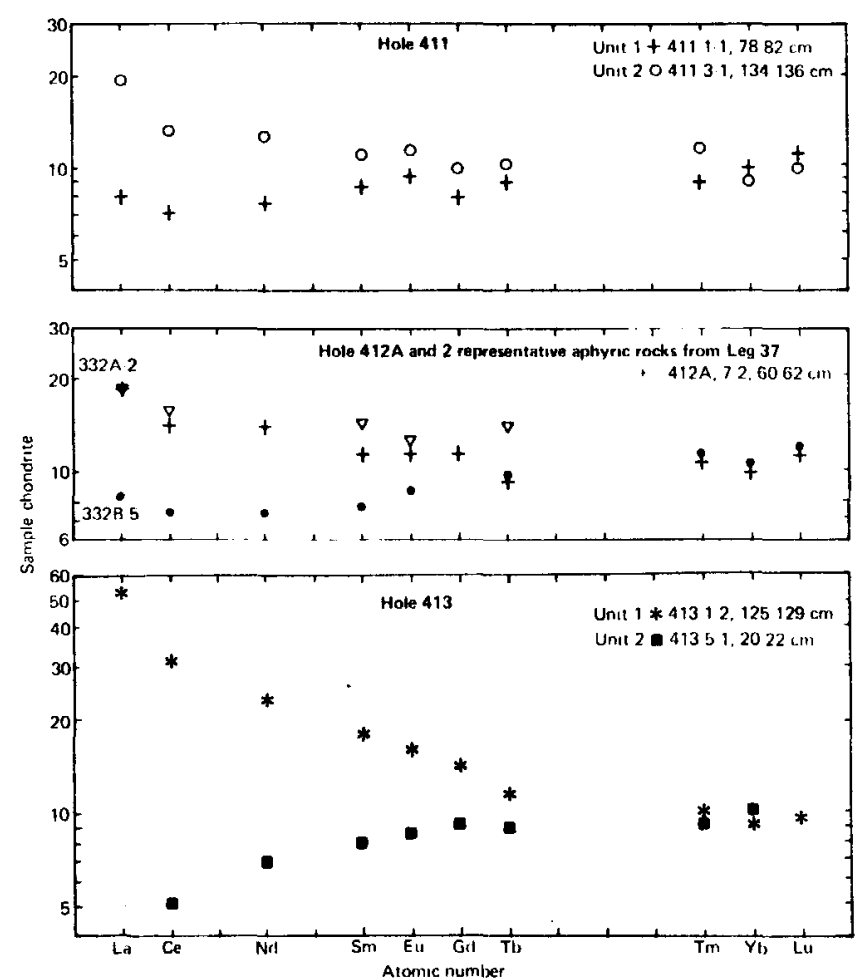

Figure 43. Masuda-Coryell plot for REE in basalts of $37^{\circ} \mathrm{N}$ sites. Hole $412 \mathrm{~A}$ values are compared with magma types $A$ and $B$ of Flower et al. (1977); REE from Schilling (1977).

basalts of this region. Partial melting of a homogeneous mantle source containing a refractory hydrous phase or phases enriched in some of the HYG elements (e.g., phlogopite and apatite) in which the phases do not equilibrate with each other or the melt, has been proposed to explain the range of ${ }^{87} \mathrm{Sr} /{ }^{86} \mathrm{Sr}$ and trace-element ratios in these basalts (O'Nions and Pankhurst, 1974; Flower et al., 1975). It is doubtful whether disequilibrium could be maintained during melting (Hofmann and Hart, 1976), or even if disequilibrium melting is capable of producing the observed chemical variations in the basalts ( $\mathrm{O}^{\prime}$ Nions et al., 1976). Also, the existence of $\mathrm{Pb}$-isotope variation, as well as $\mathrm{Sr}$-isotope variation, means that a minor mantle phase enriched in radiogenic lead isotopes is also required if this model is to explain all the chemical variation. Although these considerations make the disequilibrium melting process seem an unlikely alternative, the lack of present knowledge about the stability of minor phases in the upper mantle, and their effect on HYG elements at the relevant temperatures and pressures, makes it impossible to reject this model completely.

O'Hara (1977) has proposed an open-system crystal fractionation process which can significantly modify the ratios of HYG-element/less incompatible trace element. The model involves the fractionation of a liquid in a magma chamber, with intermittent replenishment with the parental liquid and partial extraction of the fractionated liquid. The behavior of a trace element in the steady-state liquid is governed by an equation dependent mainly on the $X / Y$ ratio (where $\mathrm{X}$ is the fraction of liquid which crystallizes and $\mathrm{Y}$ is the fraction of liquid erupted) and the bulk partition coefficient. Pankhurst (1977) has used this equation with optimum partition coefficients and the most favorable $X / Y$ ratio for fractionation of the $\mathrm{Ce} / \mathrm{Yb}$ ratio, and has shown that this process is incapable of explaining the range of $\mathrm{Ce} / \mathrm{Yb}$ ratios observed in the basalts of this region. Pankhurst (1977) has shown that this also holds for the zone refining process (Harris, 1974). Also, it is unlikely that either of these processes could modify radiogenic isotope ratios in the liquids.

Although we consider the processes discussed in this section incapable of explaining the total range of basalt chemistry found in the Iceland and Reykjanes Ridge area; we have mentioned them to emphasize the lack of agreement among geochemists concerning the petrogenesis of ocean-floor basalts. And the possibility that some of these processes have contributed to the overall chemical diversity of these basalts cannot be ruled out.

\section{GEOCHEMICAL RELATIONSHIPS BETWEEN THE MANTLE SOURCES OF MAR BASALTS}

It is clear from the discussion above that the wide range of chemical variation in the magma types recovered from all the Leg 49 holes cannot be explained in terms of a single-stage partial melting event of a homogeneous upper mantle. Nevertheless, there is evidence to suggest that all the basalts have originally been derived from a homogeneous source. Figure 56 is a plot of La versus Ta for all the analyzed samples from Leg 49 , showing that all the magma types have the same La/Ta ratio. This is also so for the $\mathrm{La} / \mathrm{Nb}$ ratio. The close similarity of the bulk solid/liquid partition coefficients of these elements (Bougault, in press) means that their ratios cannot be modified by solid-liquid processes, and are therefore representative of the primordial source material. The variation of the Th-versus-La diagram 


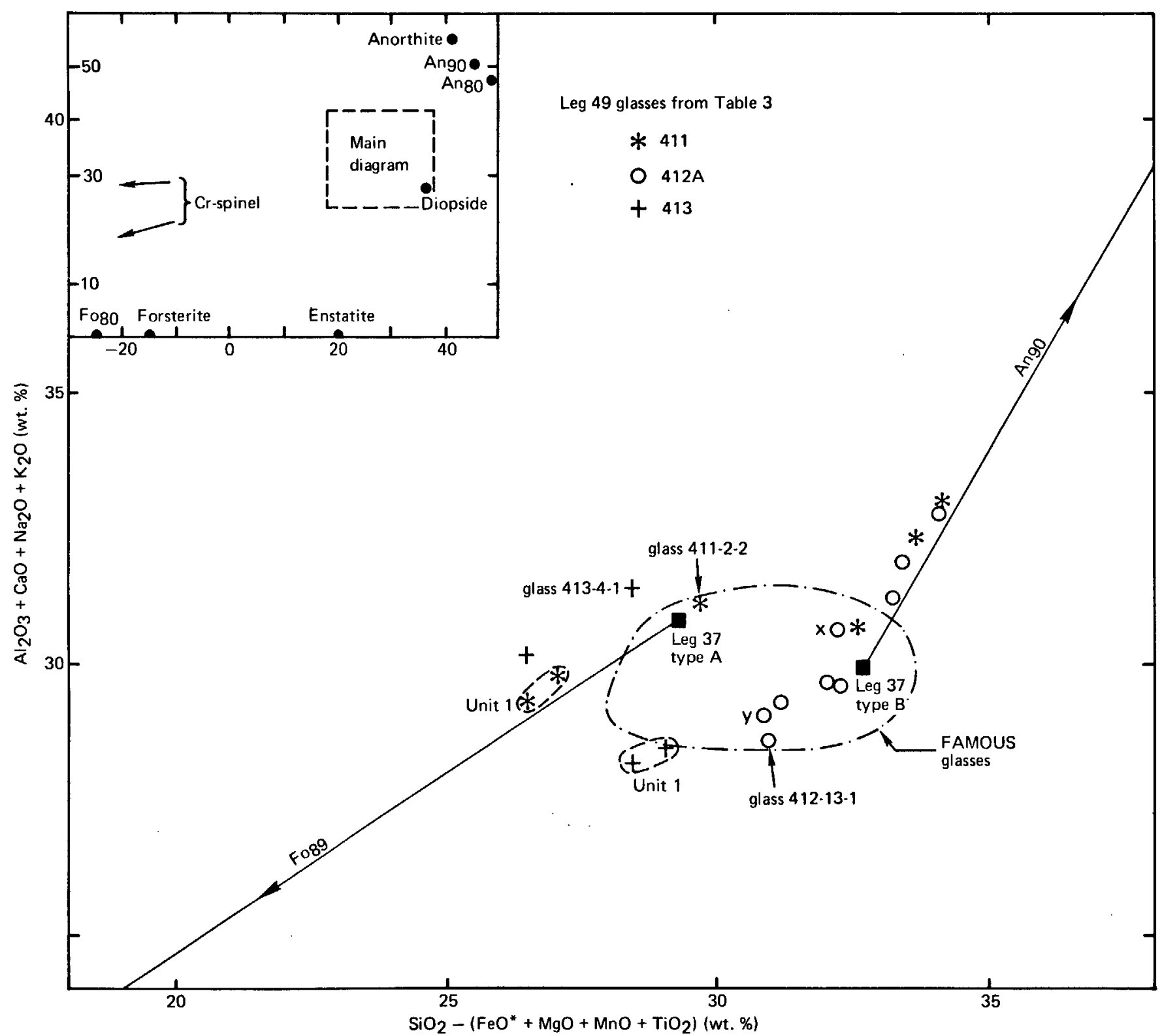

Figure 44. Plot of the major-element compositions for basalts from Holes 411,412A, and 413, compared with Flower et al. (1977) rock types $A$ and $B$ and field of composition of basaltic glasses in the FAMOUS area from Bryan and Moore (1977). Basalts from Holes 4.11 and $412 \mathrm{~A}$ lie on fractionation trend of plagioclase $(\mathrm{An} 90)$ or olivine $\left(\mathrm{Fo}_{89}\right)$.

(Figure 55[B]) suggests that the present upper mantle sources from which the MAR basalts have been derived are heterogeneous, and must therefore have suffered previous fractionation events if they have been derived from a homogeneous primordial mantle.

It is unlikely, considering the nature of the elements involved, that the heterogeneity of these HYG elements could be produced by the mobility of a volatile phase in the upper mantle (Green, 1972). The constant La/Ta ratio but variable $\mathrm{Th} / \mathrm{La}$ in the mantle sources is consistent with a model requiring an initially homogeneous mantle which suffered an incipient equilibrium partial melting event(s) (the primary source in the different regions undergoing different degrees and/or a different number of melting events) at an earlier stage of the earth's history (as suggested by the radiogenic isotope variations, Sun and Hanson,
1975). These incipient melting events may not have involved extraction of basaltic liquid from the primary source, but may have involved migration of an alkali and HYG-element-rich liquid, leaving residual secondary sources still fertile enough to produce significant volumes of basalt. The steeper oceanic geotherms in the Precambrian, supported by the eruption of ultrabasic liquids in this period, might have induced such an incipient melting event on a global scale. The residues of this early solid-liquid process would have the same La/Ta ratios, slightly different Th/La ratios, and widely different $\mathrm{Ce} / \mathrm{Yb}$ and $\mathrm{Rb} / \mathrm{Sr}$ ratios. Thus, over a period of approximately $2000 \mathrm{~m} . \mathrm{y}$., these residual sources would develop significantly different isotopic ratios. These residues would then act as secondary sources from which the basalts erupted at the MAR could be derived by subsequent partial melting events. 


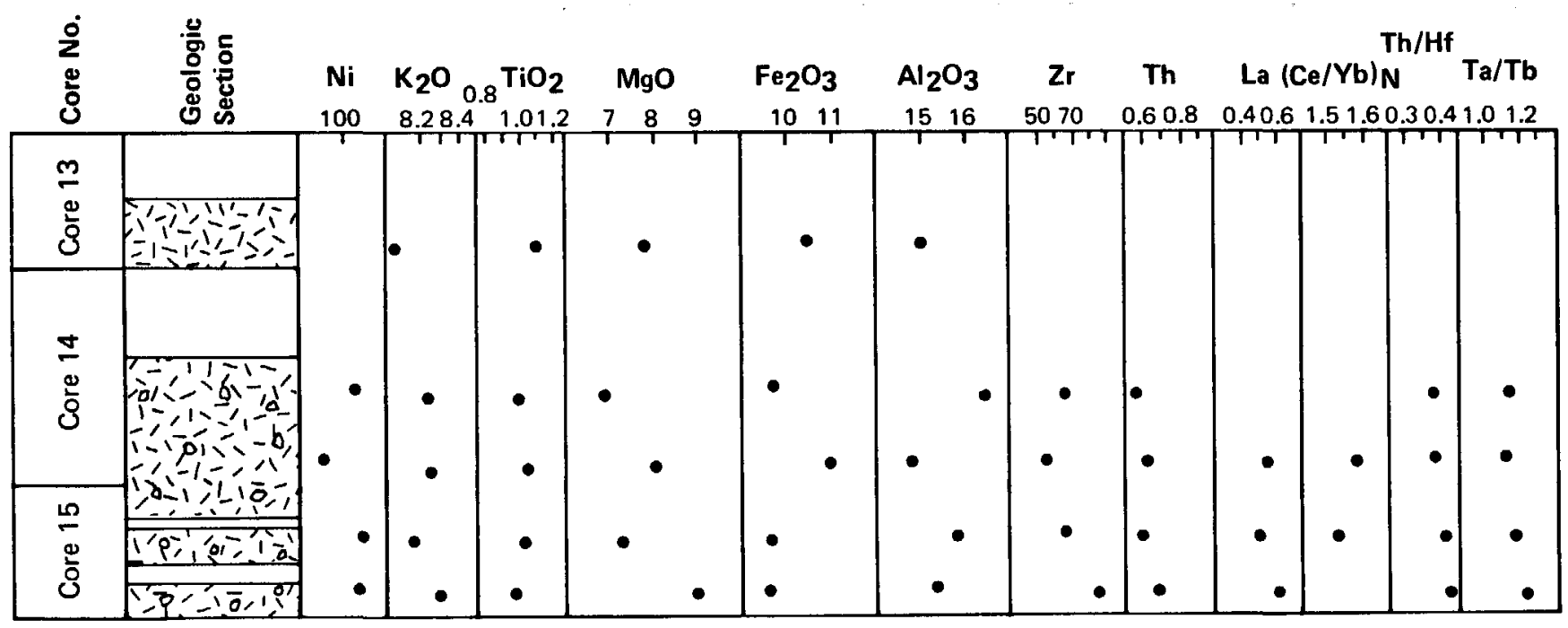

Figure 45. Detailed lithostratigraphic section for Hole 412. See Figure 3 for source of data.

We tentatively propose the model outlined above as an alternative to the mantle plume model for the origin of MAR basalts. In doing so, we stress that with our limited knowledge of the composition and nature of processes occurring in the upper mantle, the model is speculative. Although the model is capable of explaining the HYG-element and isotope variation in the MAR basalts, the overall chemical diversity in the magma types recovered by Leg 49 (Figure 57) suggests that the secondary mantle sources have undergone a range of partial melting and crystal fractionation processes.

\section{CONCLUSIONS}

The basalts constituting crustal Layer 2 of the Atlantic Ocean floor show considerable geochemical, petrological, and mineralogical diversity. Layer 2 is heterogeneous on a regional scale (longitudinally), on a local scale (latitudinally in crust produced from the same segment of the MAR at different times), and vertically (within one borehole) (Figure 57). Basalt compositions other than MORB are abundant, and form a substantially greater portion of the oceanic crust than was previously thought. All the Leg 49 basalts (except perhaps a few from $37^{\circ} \mathrm{N}$ ) have suffered significant crystal fractionation, which occurred in discrete rather than continuous magma chambers.

The range of some HYG-element ratios (e.g., Th/La) shown by the MAR basalts suggests that the upper mantle sources from which they have been derived are regionally and, in some areas at least, vertically heterogeneous. The constant values of other HYG-element ratios (e.g., La/Ta, $\mathrm{La} / \mathrm{Nb}$ ) in these basalts suggest, however, that the present upper mantle sources may have been derived from a homogeneous, primordial mantle by other, earlier fractionation events.

\section{ACKNOWLEDGMENTS}

DAW is grateful to Drs. N. Charnley and J. Long for providing time and technical advice for use of the EDS microprobe at the
Department of Mineralogy and Petrology, University of Cambridge, England.

\section{REFERENCES}

Aoki, K-I., 1964. Clinopyroxenes from alkaline rocks of Japan, American Mineralogist, v. 49. p. 1199-1223.

Arth, J.G., and Hanson, G.N., 1975. Geochemistry and origin of the early Precambrian crust of northeastern Minnesota, Geochimica et Cosmochimica Acta, v. 39, p. 325-362.

Aumento, F., 1968. The Mid-Atlantic Ridge near $45^{\circ} \mathrm{N}$. II. Basalts from the area of Confederation Peak, Canadian Journal of Earth Sciences, v. 5, p. 1-21.

Aumento, F., Loncarevic, B.D., and Ross, D.I., 1971. Hudson Geotraverse: geology of the Mid-Atlantic Ridge at $45^{\circ} \mathrm{N}$, Philosophical transactions of the Royal Society London, Series A, v. 268, p. 623-650.

Aumento. F., and Loubat, H., 1971. The Mid-Atlantic Ridge near $45^{\circ} \mathrm{N}$. XVI. Serpentinized ultramafic intrusions, Canadian Journal of Earth Sciences, v. 8, p. 631-663.

Blanchard, D.P., Rhodes, J.M., Dungan, M.A., Rodgers, K.V., Donaldson, C.H., Brannon, J.C., Jacobs, J.W., and Gibson, E.K., 1976. The chemistry and petrology of basalts from leg 37 of the Deep Sea Drilling Project, Journal of Geophysical Research, v. 81, p. 4231-4246.

Bougault, H., and Hekinian, R,, 1974. Rift valley in the Atlantic Ocean near $36^{\circ} 50^{\prime} \mathrm{N}$ : petrology and geochemistry of basaltic rocks, Earth and Planetary Science Letters, v. 24, p. 249-261.

Bougault. H., Cambon, P., and Toulhoat, H., 1977. X-ray spectrometric analysis of trace elements in rocks. Correction for instrumental interferences, $X$-ray Spectrometry, v. 6 , p. 66-72.

Bougault, H., Treuil, M., and Joron, L., in press. Trace elements: fractional crystallization and partial melting processes, heterogeneity of the upper mantle material. In Melson, W.G., Rabinowitz, P.D., et al., Initial Reports of the Deep Sea Drilling Project, v. 45: Washington (U.S. Government Printing Office).

Brown, G.M., and Vincent, E.A., 1963. Pyroxenes from the late stages of fractionation of the Skaergaard intrusion, East Greenland, Journal of Petrology, v. 4, p. 175-197.

Bryan, W.B., and Moore, J.G., 1977. Compositional variations of young basalts in the Mid-Atlantic Ridge rift valley near lat. $36^{\circ} 49^{\prime} \mathrm{N}$, Geological Society of America Bulletin, v. 88, p. $556-570$. 
PETROLOGY, GEOCHEMISTRY, AND MINERALOGY

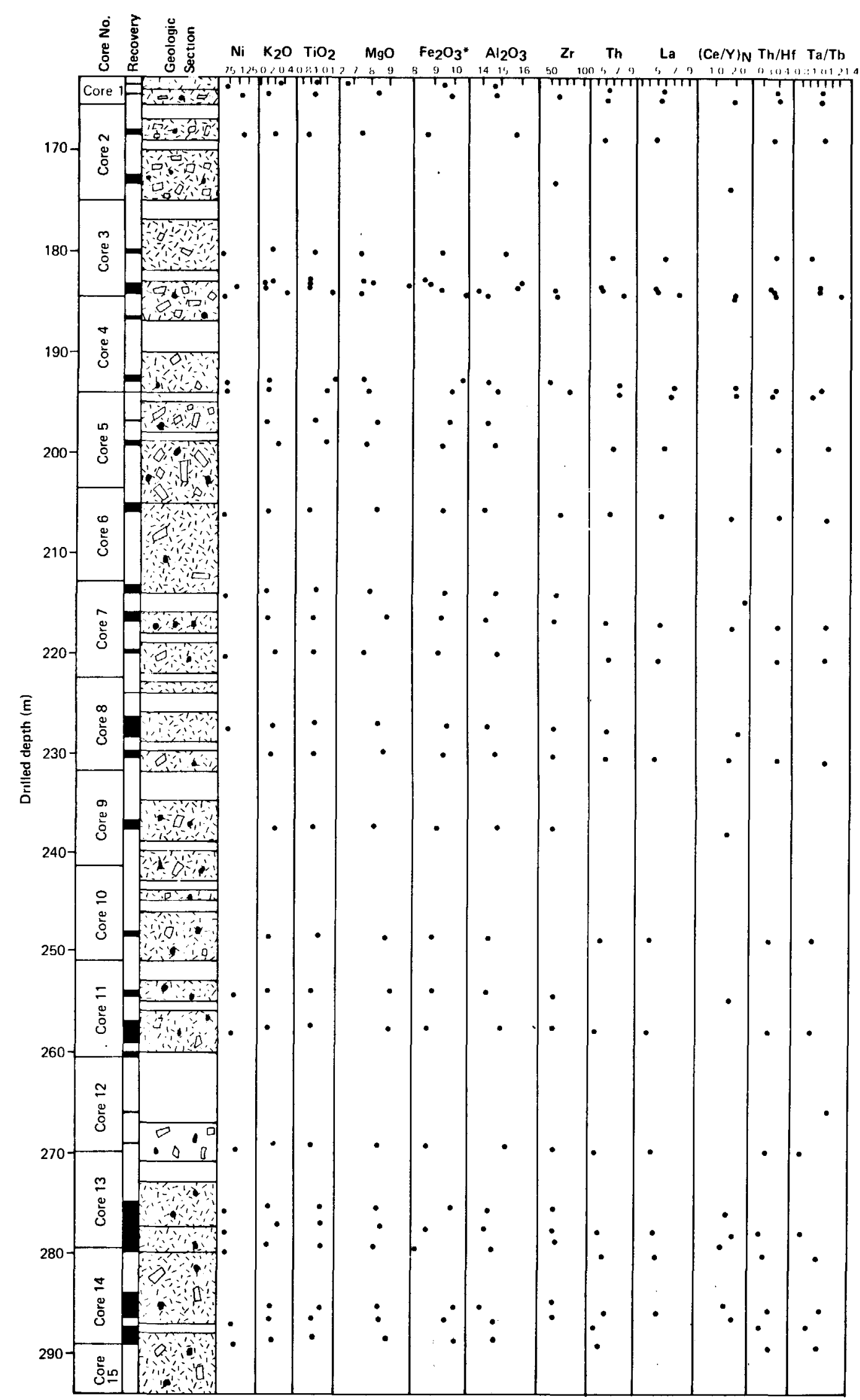

Figure 46. Detailed lithostratigraphic section for Hole 412A. See Figure 3 for source of data. Three cycles are distinguished. 
D. A. WOOD ET AL.
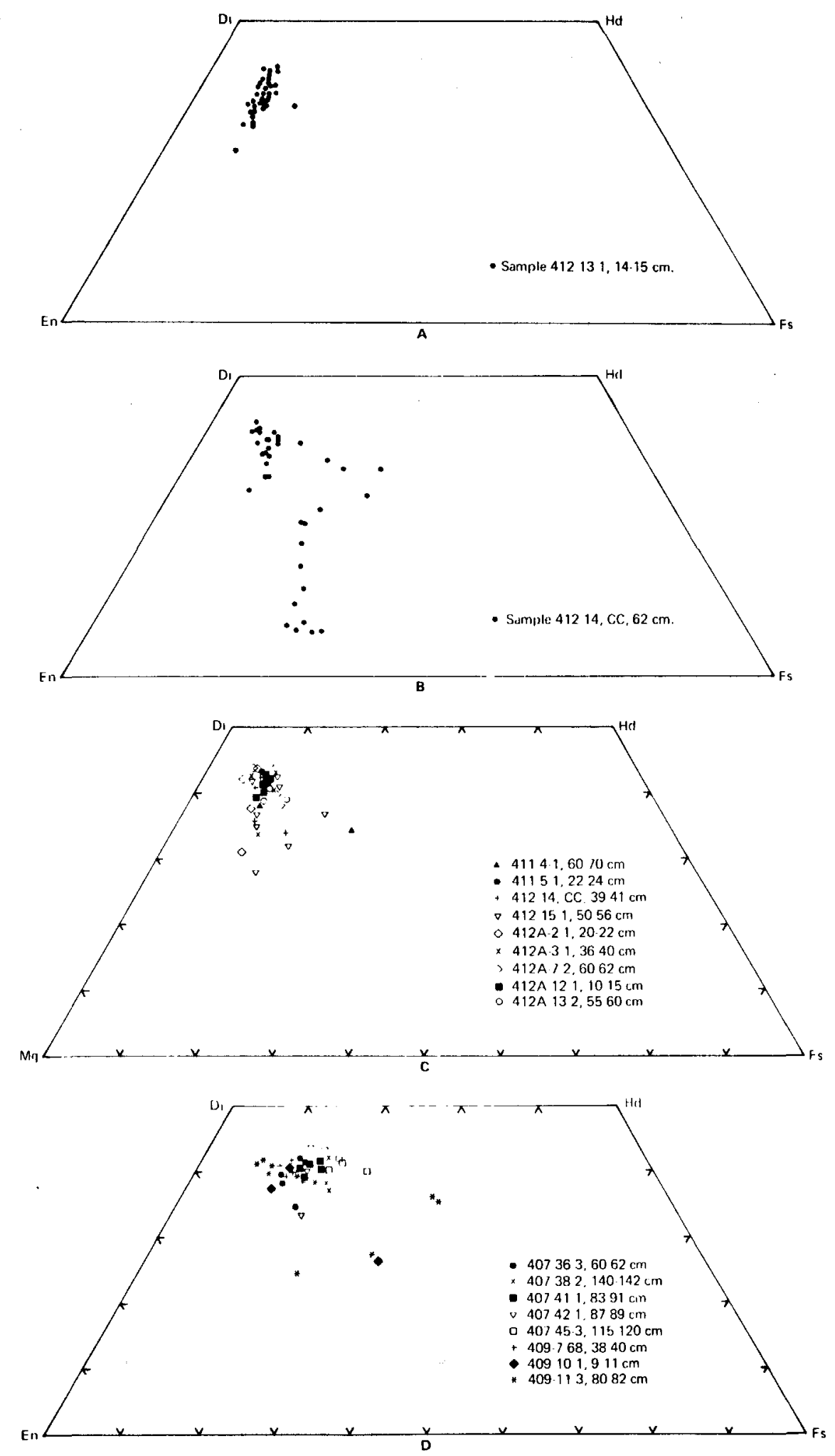

Figure 47. Microprobe analysis of pyroxene from $37^{\circ} \mathrm{N}$ sites of Leg 49. (A) Sample 412-13-1, 14-15 cm: trend towards Ca-poor compositions, with no iron enrichment (Bizouard, this paper). (B) Sample 412-14-CC, $62 \mathrm{~cm}$ : two trends, one versus pigeonitic composition, the second versus iron-enriched pvroxenes (Bizouard, this paper). (C) Analysis of various pyroxenes from Sites 411 and 412 (Wood, this paper). (D) Analysis of various pyroxenes from Sites 407 and 409 (Wood, this paper). 
TABLE 21

Representative Clinopyroxene Analyses (Holes 412 and 412A), Normalized to Six Oxygens

\begin{tabular}{|c|c|c|c|c|c|c|c|c|c|c|c|}
\hline $\begin{array}{c}\text { Sample } \\
\text { (Interval in } \mathrm{cm} \text { ) }\end{array}$ & 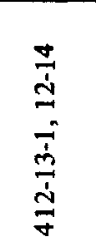 & 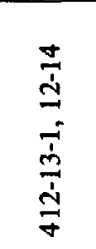 & 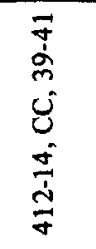 & 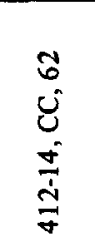 & 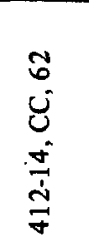 & 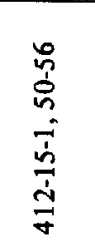 & 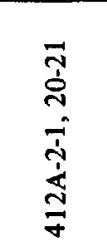 & 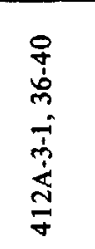 & 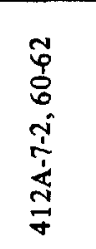 & 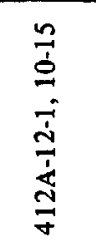 & 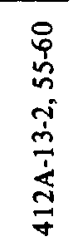 \\
\hline $\mathrm{SiO}_{2}$ & 52.68 & 52.21 & 53.04 & 51.69 & 50.69 & 52.78 & 53.79 & 52.53 & 52.04 & 52.57 & 52.41 \\
\hline $\mathrm{Al}_{2} \mathrm{O}_{3}$ & 2.99 & 3.27 & 2.48 & 3.61 & 2.44 & 2.66 & 2.77 & 2.91 & 3.51 & 4.33 & 2.41 \\
\hline $\mathrm{FeO}^{*}$ & 5.18 & 6.50 & 4.30 & 5.97 & 13.47 & 4.07 & 3.39 & 3.96 & 5.69 & 5.58 & 6.03 \\
\hline $\mathrm{MnO}$ & 0.16 & 0.27 & - & 0.25 & 0.32 & - & - & 0.20 & - & - & - \\
\hline $\mathrm{MgO}$ & 18.15 & 18.55 & 17.88 & 16.99 & 14.89 & 18.33 & 18.59 & 17.94 & 18.31 & 17.83 & 17.56 \\
\hline $\mathrm{CaO}$ & 19.50 & 17.80 & 20.44 & 19.48 & 16.75 & 20.42 & 21.01 & 20.78 & 18.38 & 19.49 & 19.95 \\
\hline $\mathrm{TiO}_{2}$ & 0.46 & 0.36 & 0.22 & 0.60 & 1.01 & 0.31 & - & - & 0.50 & - & 0.49 \\
\hline $\mathrm{Cr}_{2} \mathrm{O}_{3}$ & 0.47 & 0.25 & 0.54 & 0.49 & - & 0.42 & 0.68 & 0.66 & 0.30 & - & - \\
\hline $\mathrm{Na}_{2} \mathrm{O}$ & 0.26 & 0.21 & - & 0.24 & 0.17 & - & - & - & - & - & - \\
\hline Total & 99.85 & 99.42 & 98.88 & 99.32 & 99.74 & 99.00 & 100.23 & 98.98 & 98.73 & 99.80 & 98.85 \\
\hline $\mathbf{S i}$ & 1.92 & 1.92 & 1.95 & 1.91 & 1.91 & 1.93 & 1.94 & 1.93 & 1.91 & 1.91 & 1.94 \\
\hline $\mathrm{Al}^{\mathrm{IV}}$ & 0.08 & 0.08 & 0.05 & 0.09 & 0.09 & 0.07 & 0.06 & 0.07 & 0.09 & 0.09 & 0.06 \\
\hline $\mathrm{Al}^{\mathrm{VI}}$ & 0.05 & 0.06 & 0.05 & 0.07 & 0.02 & 0.04 & 0.06 & 0.06 & 0.06 & 0.10 & 0.04 \\
\hline $\mathrm{Fe}$ & 0.16 & 0.20 & 0.14 & 0.18 & 0.43 & 0.12 & 0.10 & 0.12 & 0.18 & 0.17 & 0.19 \\
\hline $\mathrm{Mn}$ & 0.01 & 0.01 & - & 0.01 & 0.01 & - & - & 0.01 & - & - & - \\
\hline $\mathbf{M g}$ & 0.99 & 1.01 & 0.98 & 0.93 & 0.84 & 1.00 & 1.00 & 0.98 & 1.00 & 0.97 & 0.97 \\
\hline $\mathrm{Cu}$ & 0.76 & 0.70 & 0.81 & 0.77 & 0.68 & 0.80 & 0.81 & 0.82 & 0.72 & 0.76 & 0.79 \\
\hline $\mathrm{Ti}$ & 0.01 & 0.01 & 0.01 & 0.02 & 0.03 & 0.01 & - & - & 0.01 & - & 0.01 \\
\hline $\mathrm{Cr}$ & 0.01 & 0.01 & 0.02 & 0.01 & - & 0.01 & 0.02 & 0.02 & 0.01 & - & - \\
\hline $\mathrm{Na}$ & 0.02 & 0.02 & & 0.02 & 0.01 & - & - & - & - & - & - \\
\hline $\mathrm{Mg} / \mathrm{Mg}+\mathrm{Fe}^{2+} \%$ & 85.8 & 83.0 & 88.12 & 82.9 & 65.8 & 88.91 & 90.73 & 88.98 & 85.14 & 85.07 & 83.85 \\
\hline Wo & 39.9 & 36.4 & 42.00 & 40.6 & 34.7 & 41.59 & 42.44 & 42.57 & 38.06 & 40.06 & 40.64 \\
\hline En & 51.6 & 52.8 & 51.11 & 49.3 & 42.9 & 51.93 & 52.22 & 51.10 & 52.74 & 50.99 & 49.77 \\
\hline Fs & 8.5 & 10.8 & 6.89 & 10.1 & 22.3 & 6.48 & 5.34 & 6.33 & 9.20 & 8.95 & 9.59 \\
\hline $\begin{array}{l}\text { Crystal } \\
\text { type } \\
\end{array}$ & $\mathrm{mp}$ & g & p & $\mathrm{mp}$ & $\mathrm{g}$ & $\mathbf{p}$ & $\mathbf{p}$ & $\mathbf{p}$ & $\mathrm{mp}$ & p & g \\
\hline
\end{tabular}

Bryan, W.B., Thompson, G., Frey, F.A., Dickey, J.S., and Roy, S., 1977. Petrology and geochemistry of basement rocks recovered on Leg 37, DSDP. In Aumento, F., Melson, W.G., et al., Initial Reports of the Deep Sea Drilling Project, v. 37: Washington (U.S. Government Printing Office), p. 695-704.

Campsie, J., Bailey, J.C., Rasmussen, M., and Dittmer, F., 1973. Chemistry of tholeiites from the Reykjanes Ridge and Charlie Gibbs Fracture Zone, Nature Physical Science, v. 244, p. $71-73$.

Chayla, B., Vafrezic, H., et Joron, J.L., 1973. Analyse par activation dans les mentions épithermiques. Application à la détermination d'éléments en trace dans les roches, C.R. Acad. Science Paris, v. 277, p. 273-275.

Dmitriev, L.V., 1974. Petrochemical study of the basaltic basement of the Mid-Indian Ridge; Leg 24. Djibouti to Mauritius. In Fisher, R., Bunce, E.T., et al., Initial Reports of the Deep Sea Drilling Project, v. 24: Washington (U.S. Government Printing Office), p. 767-779.

Erlank, A.J., and Kable, E.J.D., 1976. The significance of incompatible elements in the Mid-Atlantic Ridge basalts from $45^{\circ} \mathrm{N}$ with particular reference to $\mathrm{Zr} / \mathrm{Nb}$, Contributions to Mineralogy and Petrology, v. 54, p. 281-291.

Evans, B.W., and Wright, T.L., 1972, Composition of liquidus chromite from the 1959 (Kilauea Iki) and 1965 (Makaopuhi) eruptions of Kilauea Volcano, Hawaii, American Mineralogist, v. 57, p. $217-230$.
Flower, M.F.J., Schmincke, H.U., and Thompson, R.N., 1975. Phlogopite stability and the ${ }^{87} \mathrm{Sr} /{ }^{88} \mathrm{Sr}$ step in basalts along the Reykjanes Ridge, Nature, v. 254, p. 404-406.

Flower, M.F.J., Robinson, P.T., Schmincke, H.U., and Ohnmacht, W., 1977. Petrology and geochemistry of igneous rocks; DSDP Leg 37. In Aumento, F., Melson, W.G., et al., Initial Reports of the Deep Sea Drilling Project, v. 37: Washington (U.S. Government Printing Office), p. 658-680.

Frey, F.A., Haskin, M.A., Poetz, J.A., and Haskin, L.A., 1968. Rare earth abundances in some basic rocks, Journal of Geophysical Research, v. 73, p. 6085-6097.

Frey, F.A., Bryan, W.B., and Thompson, G., 1974. Atlantic Ocean floor: geochemistry and petrology of basalts from Legs 2 and 3 of the DSDP, Journal of Geophysical Research, v. 79, p. 5507-5527.

Gast, P.W., 1968. Trace element fractionation and the origin of tholeiitic and alkaline magma types, Geochimica et Cosmochimica Acta, v. 32, p. 1057-1086.

Green, H.W., 1972. A $\mathrm{CO}_{2}$ charged asthenosphere, Nature Physical Science, v. 238, p. 2-5.

Harris, P.G., 1974. Origin of alkaline magmas as a result of anatexis. In Sørenson, H. (Ed.), The alkaline rocks: New York (Wiley), p. 427-436.

Hart, S.R., 1971. K, Rb, Cs, $\mathrm{Sr}$ and Ba contents and $\mathrm{Sr}$ isotope ratios of ocean floor basalts, Philosophical Transactions of the Royal Society London, Series A, v. 268, p. 573-588. 


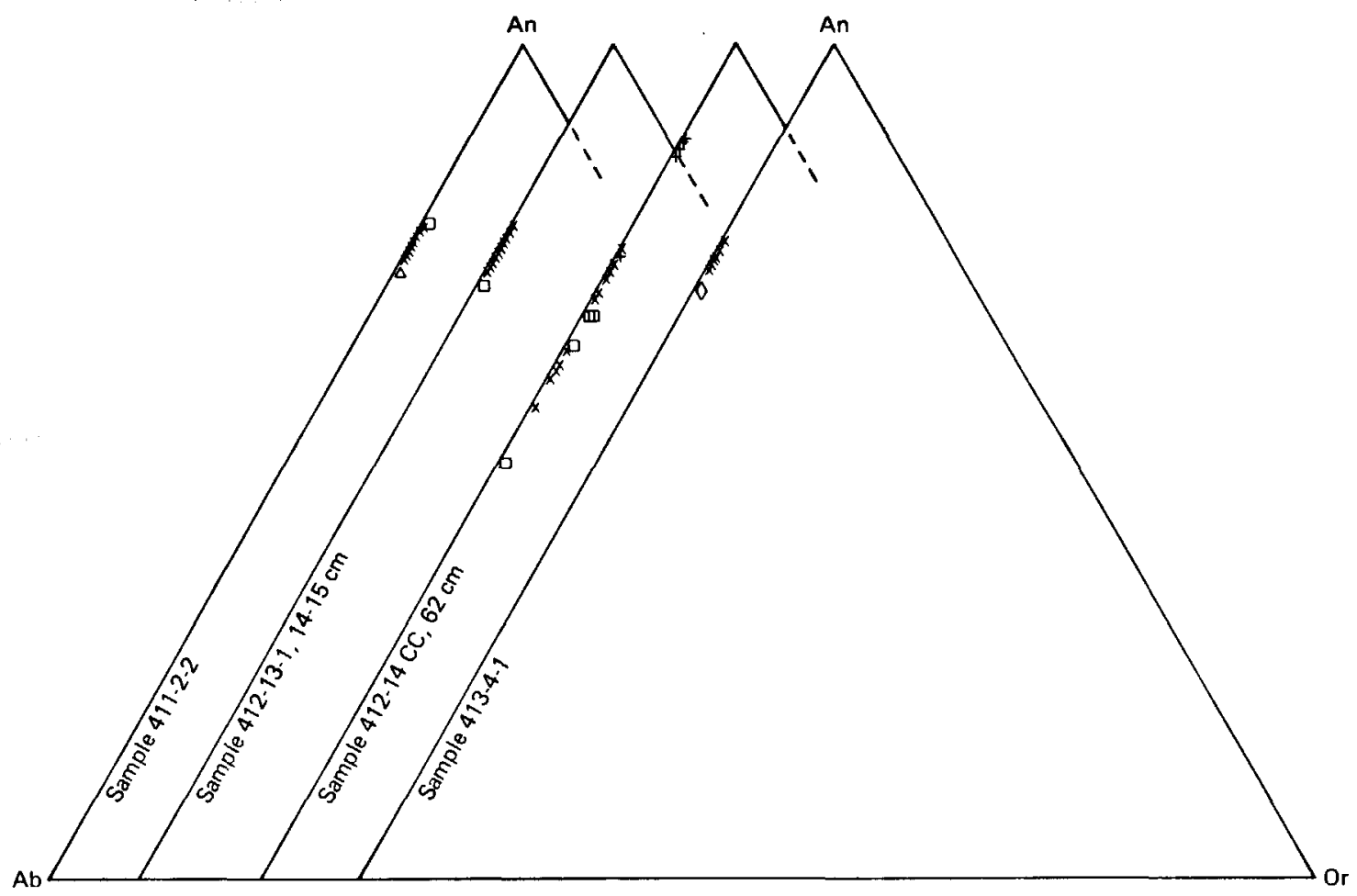

Figure 48. Plagioclase compositional variations for four selected samples from $3^{\circ} \mathrm{N}$ sites $($ Holes 411,412 , and 413). Note Ca-rich cores in Sample 412-14, CC.

TABLE 22

Representative Plagioclase Analyses (Holes 412, $412 \mathrm{~A}$, and 413), Normalized to Eight Oxygens

\begin{tabular}{|c|c|c|c|c|c|c|c|c|c|c|c|c|c|c|}
\hline $\begin{array}{c}\text { Sample } \\
\text { (Interval in cm) }\end{array}$ & 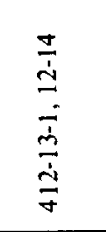 & 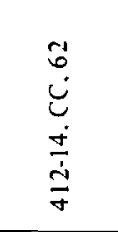 & $\begin{array}{l}\hat{b} \\
\dot{U} \\
\dot{ \pm} \\
\dot{\Xi} \\
\dot{J}\end{array}$ & 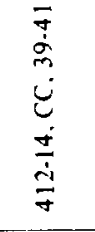 & 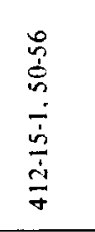 & 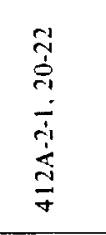 & 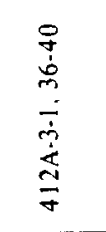 & $\begin{array}{l}\tilde{o} \\
\dot{0} \\
0 \\
i \\
\dot{I} \\
\dot{d} \\
\frac{1}{\sigma}\end{array}$ & $\begin{array}{l}\frac{i}{0} \\
\dot{0} \\
\frac{j}{\sigma} \\
\frac{j}{2} \\
\frac{1}{\sigma}\end{array}$ & 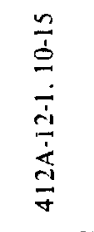 & $\begin{array}{l}\frac{n}{0} \\
0 \\
\frac{\dot{\sigma}}{\sim} \\
\frac{1}{d} \\
\frac{d}{\sigma}\end{array}$ & 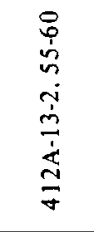 & 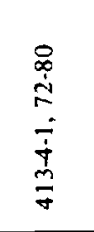 & 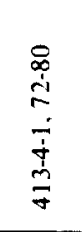 \\
\hline $\mathrm{SiO}_{2}$ & 50.61 & 47.05 & 51.42 & 47.94 & 45.59 & 46.56 & 46.75 & 46.80 & 47.51 & 49.70 & 50.84 & 46.75 & 50.14 & 50.25 \\
\hline $\mathrm{Al}_{2} \mathrm{O}_{3}$ & 30.49 & 35.13 & 31.31 & 32.81 & 34.37 & 33.51 & 33.90 & 33.71 & 32.76 & 32.13 & 30.97 & 34.66 & 30.93 & 30.61 \\
\hline $\mathrm{IcO}^{*}$ & 0.88 & 0.41 & 0.67 & 0.37 & 0.32 & 0.31 & & 0.39 & 0.50 & 0.29 & 0.33 & 0.49 & 0.68 & 0.75 \\
\hline $\mathrm{C} \cdot \mathrm{O}$ & 15.35 & 18.05 & 14.96 & 16.79 & 18.41 & 17.56 & 17.97 & 17.62 & 16.16 & 15.99 & 15.17 & 17.78 & 15.20 & 14.90 \\
\hline $\mathrm{Na}_{2} \mathrm{O}$ & 2.73 & 1.38 & 3.31 & 1.36 & 0.52 & 1.01 & 0.87 & 0.90 & 2.11 & 1.83 & 2.79 & 1.31 & 2.79 & 2.87 \\
\hline $\mathrm{K}_{2} \mathrm{O}$ & 0.08 & 0.03 & 0.04 & & & & & & & & & & 0.02 & 0.02 \\
\hline Total & 100.14 & 102.05 & 101.71 & 99.26 & 99.21 & 98.95 & 99.49 & 99.41 & 99.04 & 99.94 & 100.10 & 101.00 & 99.76 & 99.40 \\
\hline $\mathrm{Si}$ & 2.31 & 2.12 & 2.31 & 2.21 & 2.11 & 2.16 & 2.16 & 2.16 & 2.20 & 2.27 & 2.32 & 2.13 & 2.30 & 2.31 \\
\hline Al & 1.64 & 1.88 & 1.66 & 1.78 & 1.88 & 1.83 & 1.84 & 1.83 & 1.79 & 1.73 & 1.66 & 1.86 & 1.67 & 1.66 \\
\hline $\mathrm{re}$ & 0.03 & 0.01 & 0.02 & 0.01 & 0.01 & 0.01 & - & 0.01 & 0.02 & 0.01 & 0.01 & 0.02 & 0.02 & 0.02 \\
\hline Ca & 0.75 & 0.87 & 0.72 & 0.83 & 0.92 & 0.87 & 0.89 & 0.87 & 0.80 & 0.78 & 0.74 & 0.87 & 0.75 & 0.73 \\
\hline $\mathrm{Na}$ & 0.24 & 0.12 & 0.29 & 0.12 & 0.05 & 0.09 & 0.08 & 0.08 & 0.19 & 0.16 & 0.25 & 0.12 & 0.25 & 0.26 \\
\hline K & 0.00 & 0.00 & 0.00 & & & & & & & & & & 0.00 & 0.00 \\
\hline An & 75.37 & 87.70 & 71.25 & 87.22 & 95.15 & 90.56 & 91.99 & 91.58 & 80.85 & 82.84 & 75.01 & 88.21 & 74.98 & 74.13 \\
\hline$A b$ & 24.28 & 12.12 & 28.52 & 12.78 & 4.85 & 9.44 & 8.01 & 8.42 & 19.15 & 17.16 & 24.99 & 11.79 & 24.90 & 25.81 \\
\hline Or & 0.35 & 0.17 & 0.23 & & & & & & & & & & 0.12 & 0.06 \\
\hline $\begin{array}{l}\text { Crystal } \\
\text { type }\end{array}$ & $\mathrm{mp}$ & $p$ (core) & $p(\mathrm{rim})$ & p & mega $p$ & mega p & mega p & mega $p$ & $\mathrm{mp}$ & $m p$ & $g$ & $\mathrm{mp}$ & $\mathrm{mp}$ & $\mathrm{g}$ \\
\hline
\end{tabular}


TABLE 23

Representative Olivine Analyses (Holes 412,412A, and 413), Normalized to Four Oxygens

\begin{tabular}{|c|c|c|c|c|c|c|c|c|c|c|c|}
\hline $\begin{array}{c}\text { Sample } \\
\text { (Interval in } \mathrm{cm} \text { ) }\end{array}$ & $\begin{array}{l}\vec{\forall} \\
o \\
\dot{m} \\
0 \\
0 \\
\dot{J} \\
\vec{d} \\
\vec{\nabla}\end{array}$ & 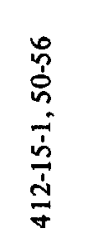 & 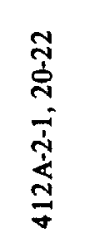 & 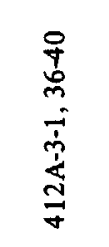 & 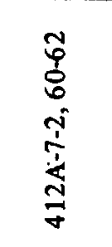 & 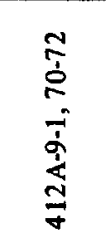 & 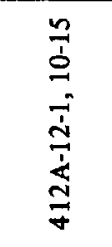 & 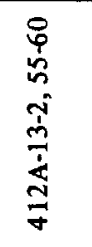 & 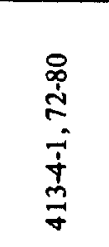 & 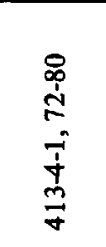 & $\begin{array}{l}\stackrel{m}{n} \\
\stackrel{n}{n} \\
\vec{n} \\
\stackrel{m}{*}\end{array}$ \\
\hline $\mathrm{SiO}_{2}$ & 41.39 & 40.60 & 40.21 & 40.72 & 39.48 & 40.19 & 40.49 & 39.72 & 40.15 & 39.85 & 40.15 \\
\hline $\mathrm{FeO}^{*}$ & 9.90 & 9.96 & 12.67 & 15.08 & 16.84 & 15.41 & 13.78 & 15.01 & 13.16 & 14.69 & 12.44 \\
\hline $\mathrm{MnO}$ & - & - & - & - & 0.23 & 0.26 & - & - & 0.17 & 0.22 & 0.23 \\
\hline $\mathrm{MgO}$ & 48.40 & 49.06 & 46.62 & 44.72 & 43.80 & 44.47 & 45.68 & 43.51 & 46.17 & 45.16 & 46.44 \\
\hline $\mathrm{CaO}$ & 0.35 & 0.24 & 0.33 & 0.32 & 0.34 & 0.33 & 0.28 & 0.36 & 0.24 & 0.33 & 0.29 \\
\hline $\mathrm{CoO}$ & - & - & - & 0.25 & 0.32 & - & - & - & - & - & - \\
\hline $\mathrm{NiO}$ & 0.30 & - & - & - & - & - & 0.35 & - & 0.41 & 0.26 & 0.26 \\
\hline Total & 100.34 & 99.86 & 99.82 & 100.50 & 101.00 & 100.66 & 100.58 & 98.59 & 100.30 & 100.57 & 99.81 \\
\hline $\mathrm{Si}$ & 1.01 & 1.00 & 1.00 & 1.00 & 0.99 & 1.00 & 1.00 & 1.01 & 1.00 & 1.00 & 1.00 \\
\hline $\mathrm{Fe}$ & 0.20 & 0.20 & 0.26 & 0.32 & 0.35 & 0.32 & 0.29 & 0.32 & 0.27 & 0.31 & 0.26 \\
\hline Mn & - & - & - & - & 0.00 & 0.01 & - & - & 0.00 & 0.00 & 0.00 \\
\hline $\mathrm{Mg}$ & 1.76 & 1.80 & 1.73 & 1.67 & 1.64 & 1.66 & 1.69 & 1.65 & 1.72 & 1.68 & 1.72 \\
\hline $\mathrm{Ca}$ & 0.01 & 0.01 & 0.01 & 0.01 & 0.01 & 0.01 & 0.01 & 0.01 & 0.01 & 0.01 & 0.01 \\
\hline Co & - & - & - & 0.01 & 0.01 & - & - & - & - & - & - \\
\hline $\mathrm{Ni}$ & 0.01 & - & - & - & - & - & 0.01 & - & 0.01 & 0.01 & 0.01 \\
\hline $\mathrm{Mg} / \mathrm{Mg}+\mathrm{Fe}^{2+} \%$ & 89.70 & 89.77 & 86.77 & 84.09 & 82.25 & 83.72 & 85.53 & 83.78 & 86.22 & 84.57 & 86.93 \\
\hline $\begin{array}{l}\text { Crystal } \\
\text { type }\end{array}$ & p & p & $\mathbf{p}$ & $\mathrm{mp}$ & $m p$ & $\mathrm{mp}$ & $\mathrm{mp}$ & $\mathrm{mp}$ & $\mathrm{mp}$ & $\mathrm{g}$ & p \\
\hline
\end{tabular}

Hart, S.R., Glassley, W.E., and Karig, D.E., 1972. Basalts and sea floor spreading behind the Mariana Island Arc, Earth and Planetary Science Letters, v. 15, p. 12-18.

Hart, S.R., Schilling, J.G., and Powell, J.L., 1973. Basalts from Iceland and the Reykjanes Ridge: Sr isotope geochemistry, Nature, v. 246, p. 104-107.

Hekinian, R., Moore, J.G., and Bryan, W.B., 1976. Volcanic rocks and processes of the Mid-Atlantic Ridge rift valley near $36^{\circ} 49^{\prime} \mathrm{N}$, Contributions to Mineralogy and Petrology, v. 58, p. 83-110.

Hofmann, A.W. and Hart, S.R., 1976. An assessment of local and regional isotopic equilibrium in a partially molten mantle, Carnegie Institute Washington Year Book, v. 75, p. 195-210.

Irvine, T.N., 1967. Chromian spinel as a petrogenetic indicator, 2. Petrologic applications, Canadian Journal of Earth Sciences, v. 4 , p. $71-103$.

Irvine, T.N., and Baragar, W.R.A., 1971. A guide to the chemical classification of common volcanic rocks, Canadian Journal of Earth Sciences, v. 8, p. 523-548.

Jackson, E.D., 1969. Chemical variation in coexisting chromite and olivine in chromitite zones of the Stillwater Complex, Economic Geology Monograph, v. 4, p. 41-71.

Lambert, R.S., and Holland, J.G., 1977. Trace elements and petrogenesis of DSDP leg 37 basalts, Canadian Journal of Earth Sciences, v. 14, p. 809-836.

Langmuir, C.H., Bender, J.F., Bence, A.E., Hanson, G.N., and Taylor, S.R., 1977. Petrogenesis of basalts from the FAMOUS area: Mid-Atlantic Ridge, Earth and Planetary Science Letters, v. 36, p. $133-156$.

Langmuir, C.H., Vocke, R.D., and Hanson, G.N., in press. A general mixing equation with applications to Icelandic basalts, Earth and Planetary Science Letters.
Mitchell, W.S. and Aumento, F., 1977. Uranium in oceanic rocks: DSDP Leg 37, Canadian Journal of Earth Sciences, v. 14, p. $794-808$.

Morgan, W.J. 1971. Convection plumes in the lower mantle, Nature, v. 230 , p. 42.

Muir, I.D., and Tilley, C.E., 1964. Basalts from the northern part of the rift zone of the Mid-Atlantic Ridge, Journal of Petrology, v. 5, p. 409-434.

Nakamura, K., 1974. Determination of REE, $\mathrm{Ba}, \mathrm{Fe}, \mathrm{Mg}, \mathrm{Na}$ and $\mathrm{K}$ in carbonaceous and ordinary chondrites, Geochimica et Cosmochimica Acta, v. 38, p. 757-775.

O'Hara, M.J., 1977. Geochemical evolution during fractional crystallization of a periodically refilled magma chamber, Nature, v. 266, p. 503-507.

O'Nions, P.K., and Pankhurst, R.J., 1974. Petrogenetic significance of isotope and trace element variations in volcanic rocks from the Mid-Atlantic, Journal of Petrology, v. 15, p. 603-634.

, 1976. Sr isotope and rare earth element geochemistry of DSDP Leg 37 basalts, Earth and Planetary Science Letters, v. 31 , p. $255-261$.

O'Nions, P.K., Pankhurst, R.J., and Gronvold, K., 1976. Nature and development of basaltic magma sources beneath Iceland and the Reykjanes Ridge, Journal of Petrology, v. 17, p. 3-30.

O'Nions, P.K., Pankhurst, R.J., Fridleifsson, I.B., and Jakobsson, S.P., 1973. Sr isotopes and rare earth elements in basalts from Heimaey and Surtsey volcanic enuptions, Nature, v. 243 , p. $213-214$.

Pankhurst, R.J., 1977. Open system crystal fractionation and incompatible element variation in basalts, Nature, v. 268 , p. 36-38. 
D. A. WOOD ET AL.

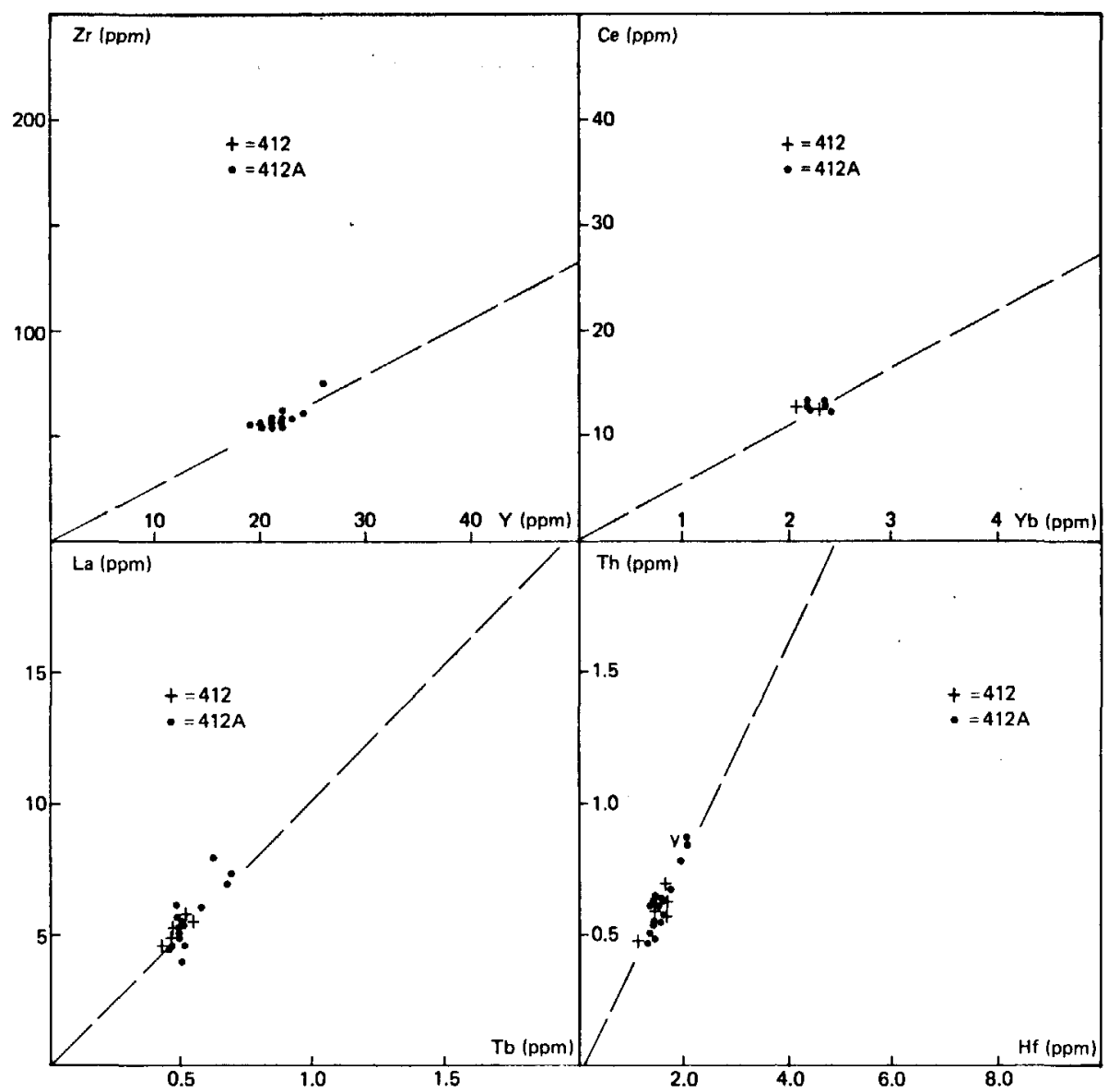

Figure 49. HYG-element plot for analyzed samples from Holes 412 (crosses) and $412 \mathrm{~A}$ (filled circles). All analyses lie on a single line passing through the origin. Dispersion indicates that variation was produced by crystal fractionation from a single magma type.

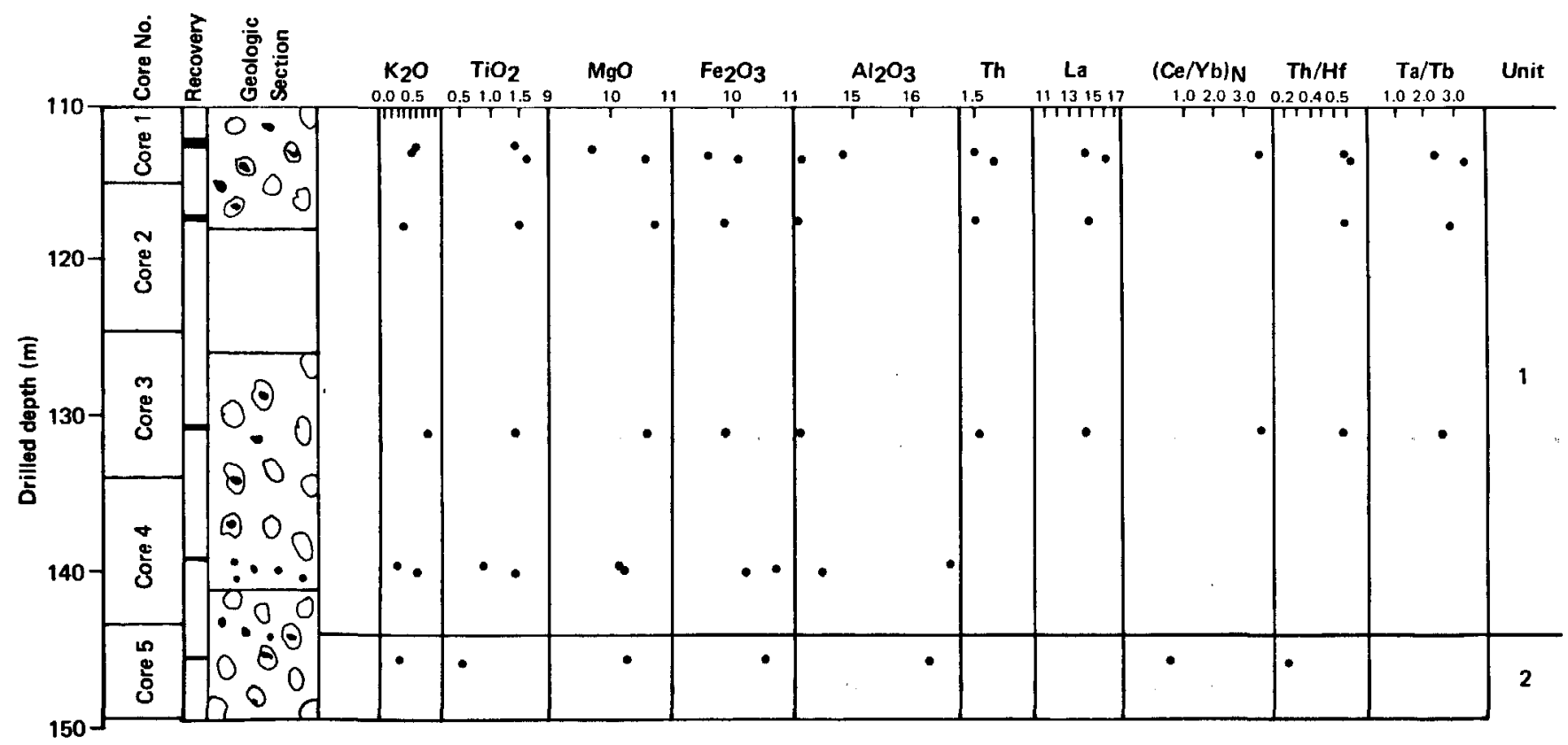

Figure 50. Detailed lithostratigraphic section for Hole 413. See Figure 3 for source of data. Two geochemical types of magma are distinguished (Units 1 and 2 /, mainly on the basis of HYG-element ratios. 
TABLE 24

Representative Magnesiochromites From Holes 412A and 413

\begin{tabular}{|c|c|c|c|c|c|c|}
\hline $\begin{array}{c}\text { Sample } \\
\text { (Interval in } \mathrm{cm} \text { ) }\end{array}$ & 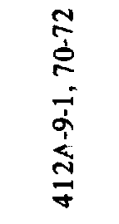 & 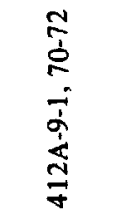 & 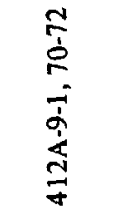 & $\begin{array}{l}\frac{i}{j} \\
\frac{i}{j} \\
\frac{i}{j} \\
\frac{j}{\sigma}\end{array}$ & $\begin{array}{l}8 \\
5 \\
\dot{5} \\
\overline{5} \\
\stackrel{5}{7} \\
7\end{array}$ & 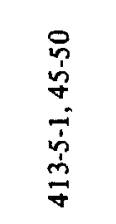 \\
\hline $\mathrm{SiO}_{2}$ & 0.48 & 0.27 & 0.34 & 0.42 & 0.24 & 0.46 \\
\hline $\mathrm{TiO}_{2}$ & 0.37 & 0.41 & 0.27 & 0.31 & 0.51 & 0.42 \\
\hline $\mathrm{Al}_{2} \overrightarrow{\mathrm{O}}_{3}$ & 19.58 & 22.48 & 20.92 & 20.84 & 31.16 & 31.31 \\
\hline $\mathrm{Cr}_{2} \mathrm{O}_{3}$ & 48.14 & 44.56 & 46.12 & 46.19 & 33.98 & 34.52 \\
\hline $\mathrm{Fe}_{2} \mathrm{O}_{3}$ & 5.28 & 5.30 & 5.75 & 4.86 & 5.76 & 5.10 \\
\hline $\mathrm{FeO}$ & 11.28 & 11.25 & 11.32 & 13.62 & 13.17 & 13.07 \\
\hline MnO & 0.42 & 0.25 & 0.34 & 0.40 & - & - \\
\hline $\mathrm{MgO}$ & 15.18 & 15.26 & 15.17 & 13.59 & 15.03 & 15.41 \\
\hline $\mathrm{CoO}$ & - & - & - & 0.31 & 0.30 & - \\
\hline $\mathrm{NiO}$ & - & 0.26 & - & - & - & - \\
\hline Total & 100.74 & 100.04 & 100.24 & 100.53 & 100.15 & 100.29 \\
\hline $\mathbf{S i}$ & 0.118 & 0.069 & 0.079 & 0.099 & 0.056 & 0.108 \\
\hline $\mathrm{Ti}$ & 0.069 & 0.069 & 0.049 & 0.059 & 0.090 & 0.074 \\
\hline Al & 5.617 & 6.412 & 5.997 & 6.016 & 8.590 & 8.586 \\
\hline $\mathrm{Cr}$ & 9.253 & 8.520 & 8.858 & 8.945 & 6.284 & 6.350 \\
\hline $\mathrm{Fe}^{3+}$ & 0.966 & 0.965 & 1.053 & 0.898 & 1.015 & 0.893 \\
\hline $\mathrm{Fe}^{2+}$ & 2.296 & 2.276 & 2.300 & 2.791 & 2.575 & 2.543 \\
\hline $\mathbf{M n}$ & 0.089 & 0.049 & 0.069 & 0.079 & - & - \\
\hline $\mathrm{Mg}$ & 5.499 & 5.506 & 5.496 & 4.961 & 5.241 & 5.345 \\
\hline Co & - & - & - & 0.059 & 0.056 & - \\
\hline $\mathrm{Ni}$ & - & 0.049 & - & - & - & - \\
\hline $\mathrm{Mg} / \mathrm{Mg}+\mathrm{Fe}^{2+}$ & 0.705 & 0.708 & 0.705 & 0.640 & 0.671 & 0.678 \\
\hline $\mathrm{Cr} / \mathrm{Cr}+\mathrm{Al}$ & 0.622 & 0.571 & 0.596 & 0.598 & 0.422 & 0.425 \\
\hline $\mathrm{Fe}^{3+} / \mathrm{Fe}^{3+}+\mathrm{Cr}+\mathrm{Al}$ & 0.061 & 0.061 & 0.066 & 0.057 & 0.064 & 0.056 \\
\hline $\begin{array}{l}\mathrm{Mg} / \mathrm{Mg}+\mathrm{Fe}^{2+} \\
\text { of host } \mathrm{Ol}\end{array}$ & 0.902 & 0.902 & 0.902 & 0.836 & 0.869 & 0.871 \\
\hline
\end{tabular}

Reed, S.J.B., and Ware, N.G., 1975. Quantitative electron microprobe analysis of silicates using energy dispersive X-ray spectrometry, Journal of Petrology, v. 16, p. 499-519.

Rucklidge, J.C., Gibb, F.G.F., Fawcett, J.J., and Gasparrini, E.L., 1970. Rapid rock analysis by electron probe, Geochimica et Cosmochimica Acta, v. 34, p. 243-247.

Schilling, J.G., 1973. Iceland mantle plume: geochemical study of the Reykjanes Ridge; Nature, v. 242, p. 565-571.

, 1975. Azores mantle blob: rare earth evidence, Earth and Planetary Science Letters, v. 25, p. 103-115.

, 1977. Rare-earth, $\mathrm{Sc}, \mathrm{Cr}, \mathrm{Fe}, \mathrm{Co}$ and $\mathrm{Na}$ abundances in DSDP Leg 38 basalts: some additional evidence on the evolution of the Thulean volcanic province. In Talwani, M., Udintsev, G., et al., Initial Reports of the Deep Sea Drilling Project, v. 38: Washington (U.S. Government Printing Office), p. 741-750.

Schilling, J.G. and Noe-Nygaard, A., 1974. Faeroe-Iceland mantle plume: rare earth evidence, Earth and Planetary Science Letters, v. 24, p. 1-12.

Shaw, D., 1970. Trace element fractionation during anatexis; Geochimica et Cosmochimica Acta, v. 34, p. 237-243.

Shimizu, N., and Kushiro, I., 1975. The partitioning of rare earth elements between garnet and liquid at high pressures: preliminary experiments, Geophysical Research Letters, v. 2, p. 413-416.
Sigurdsson, H., 1977. Spinels in Leg 37 basalts and peridotites: phase chemistry and zoning. In Aumento, F., Melson, W.G., et al., Initial Reports of the Deep Sea Drilling Project, v. 37: Washington (U.S. Government Printing Office), p. 883-891.

Sigurdsson, H. and Brown, G.M., 1970. An unusual enstatiteforsterite basalt from Kobleinsey Island, north of Iceland, Journal of Petrology, v. 11, p. 205-220.

Sigurdsson, H. and Schilling, J.G., 1976. Spinels in Mid-Atlantic Ridge basalts: chemistry and occurrence, Earth and Planetary Science Letters, v. 29, p. 7-20.

Sigvaldason, G.E., Steinthorsson, S., Imsland, P., and Oskarsson, N., 1976. The simultaneous production of basalts enriched and depleted in large lithophile trace ions (LIL), within the same fissure swarms in Iceland, Bulletin Société Geologique France, v. 18, p. 863-867.

Sun, S.S., and Hanson, G.N., 1975. Evolution of the mantle: geochemical evidence from alkali basalts, Geology, v. 3, p. 297-302.

Sun, S.S., Tatsumoto, M., and Schilling, J.G., 1975. Mantle plume mixing along the Reykjanes Ridge axis: lead isotope evidence, Science, v. 190, p. 143-147.

Tilley, C.E., Yoder, H.S., and Schairer, J.F., 1966. Melting relations of volcanic rock series, Carnegie Institute Washington Year Book, v. 65, p.260-269. 


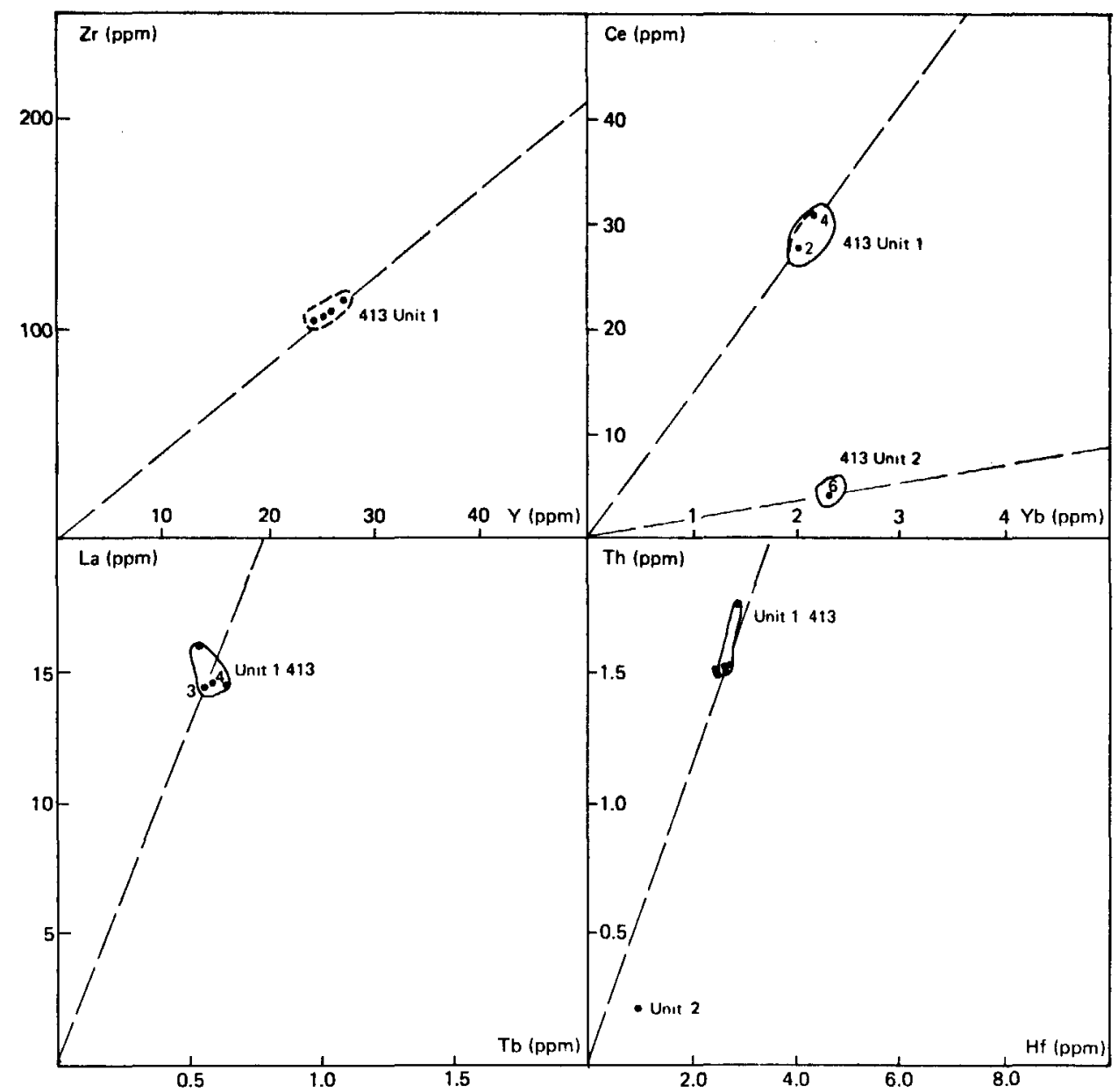

Figure 51. HYG-element variations in Hole 413. Units 1 and 2 are clearly distinguished.

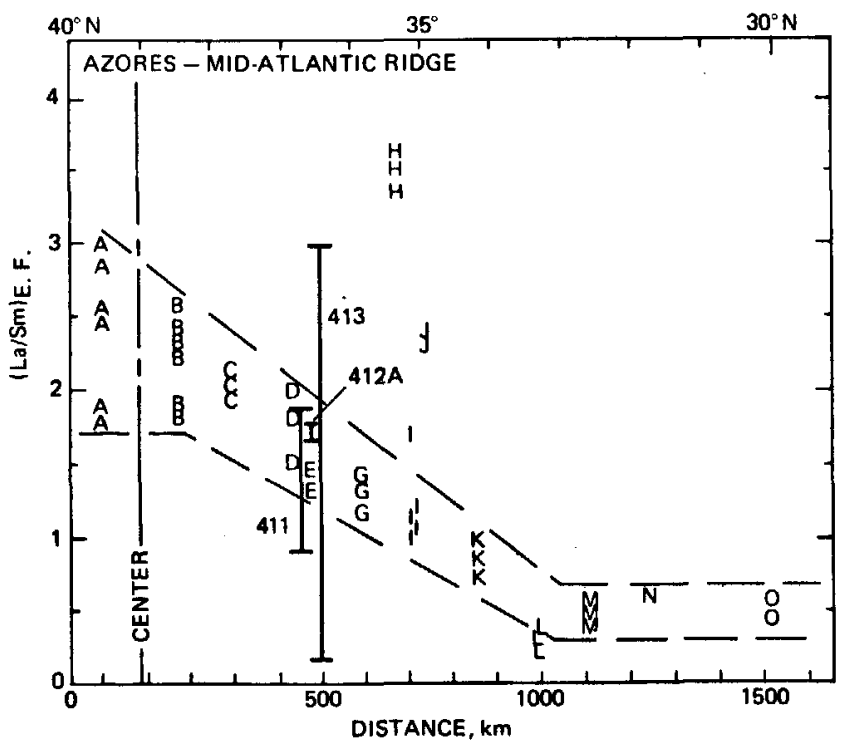

Figure 52. Variation of chondrite-normalized $\mathrm{La} / \mathrm{Sm}$ ratio in Holes 411, 412A, and 413, compared with the geochemical traverse of Schilling (1975), where ratios are plotted against latitude or radial distance from the Azores platform.
Treuil, M.M., Jafrezic, H., Deschamps, N., Derre, C., Prichard, S., Joron, J.L., Pelletier, B., Novotny, S., Courtois, C. 1973. L'analyse des lanthanides, du hafnium, du Scandium, du chrome, du manganèse, du cobalt, du cuivre et du zinc dans les minéraux et les roches par activation non tronique. Rad. Chemistry, Sp. Issue, Cong. Int. Anal, Activ. Paris, 1972.

Treuil, M. and Joron, J.L., 1975. Utilisation des éléments hygromagmatophiles pour la simplification de la modélisation quantitative des processus magmatiques: exemples de l'Afar et de la dorsale médioatlantique, Societa Italiana Mineralogia $e$ Petrologia - Milano, v. 31, p. 125-174.

Treuil, M. and Varet, J., 1973. Critères volcanologiques, pétrologiques et géochimiques de la genèse et de la différentiation des magmas basaltiques: exemple de l'Afar, Bulletin Société Géologique France, v. 15, p. 506-540.

Vogt, P.R., 1972. Evidence for global synchronism in mantle plume convection, and possible significance for geology, Nature, v. 240, p. 338-342.

Watkins, N.D. and Walker, G.P.L., 1977. Magnetostratigraphy of eastern Iceland, American Journal of Science, v. 277 , p. 513-584.

White, W.R. and Bryan, W.B., 1977. Sr isotope, K, Rb, Cs, Sr, $\mathrm{Ba}$, and rare earth geochemistry of basalts from the FAMOUS area, Geological Society of America Bulletin, v. 88, p. 571-576.

White, W.R. Hart, S.R., and Schilling, J.G., 1975. Geochemistry of the Azores and the Mid-Atlantic Ridge: $29^{\circ} \mathrm{N}$ 

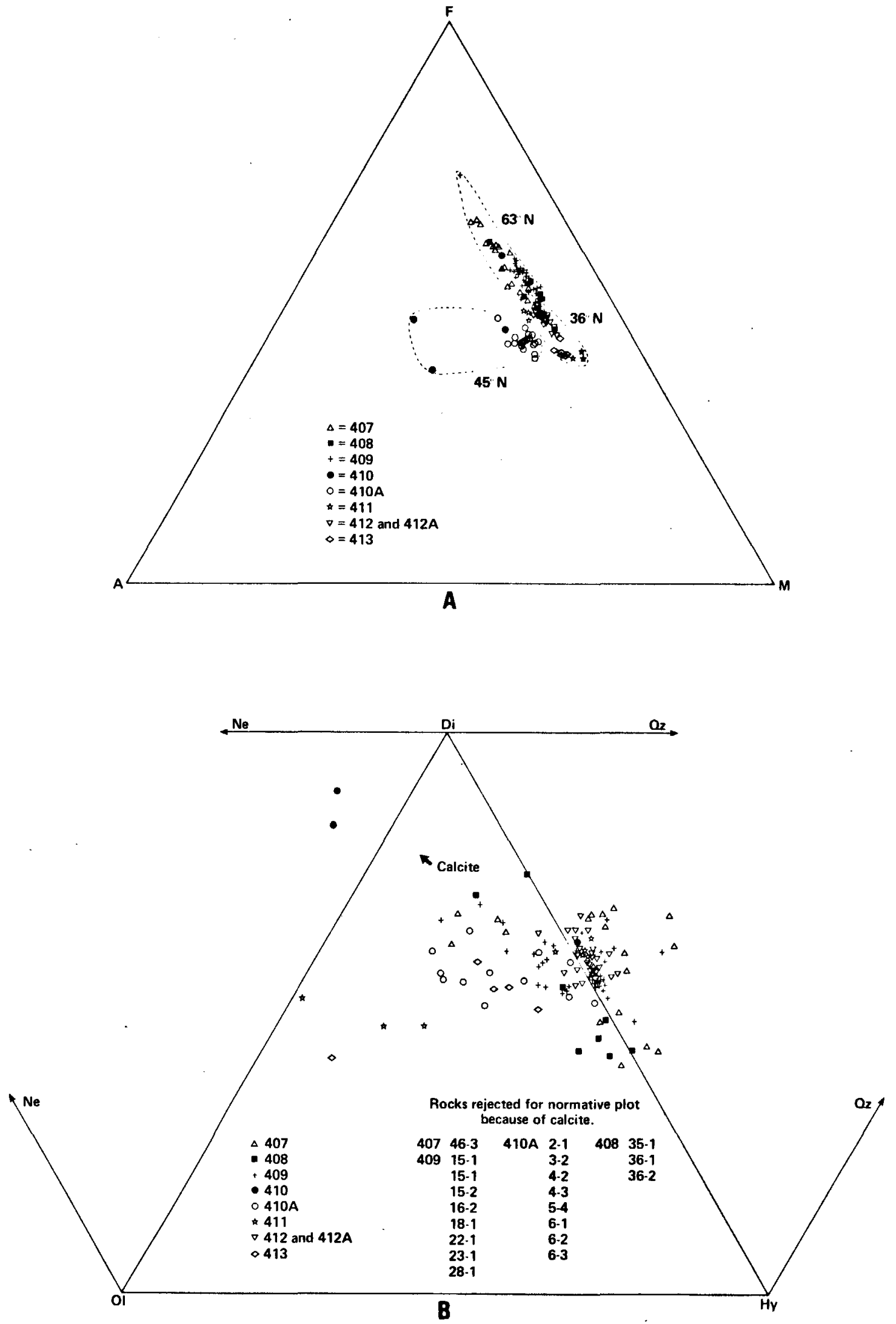

Figure 53. (A) AFM diagram for all basalt major-element analyses obtained in this paper on Leg 49. $37^{\circ} \mathrm{N}, 45^{\circ} \mathrm{N}$, and $63^{\circ} \mathrm{N}$ areas are distinguished by different contours. (B) $Q-$ di - hy - Ol - ne normative plot for all basalts analyzed in this paper. Basalts from various holes are distinguished by various indexes. Samples with more than 1 per cent modal calcite have been omitted. 


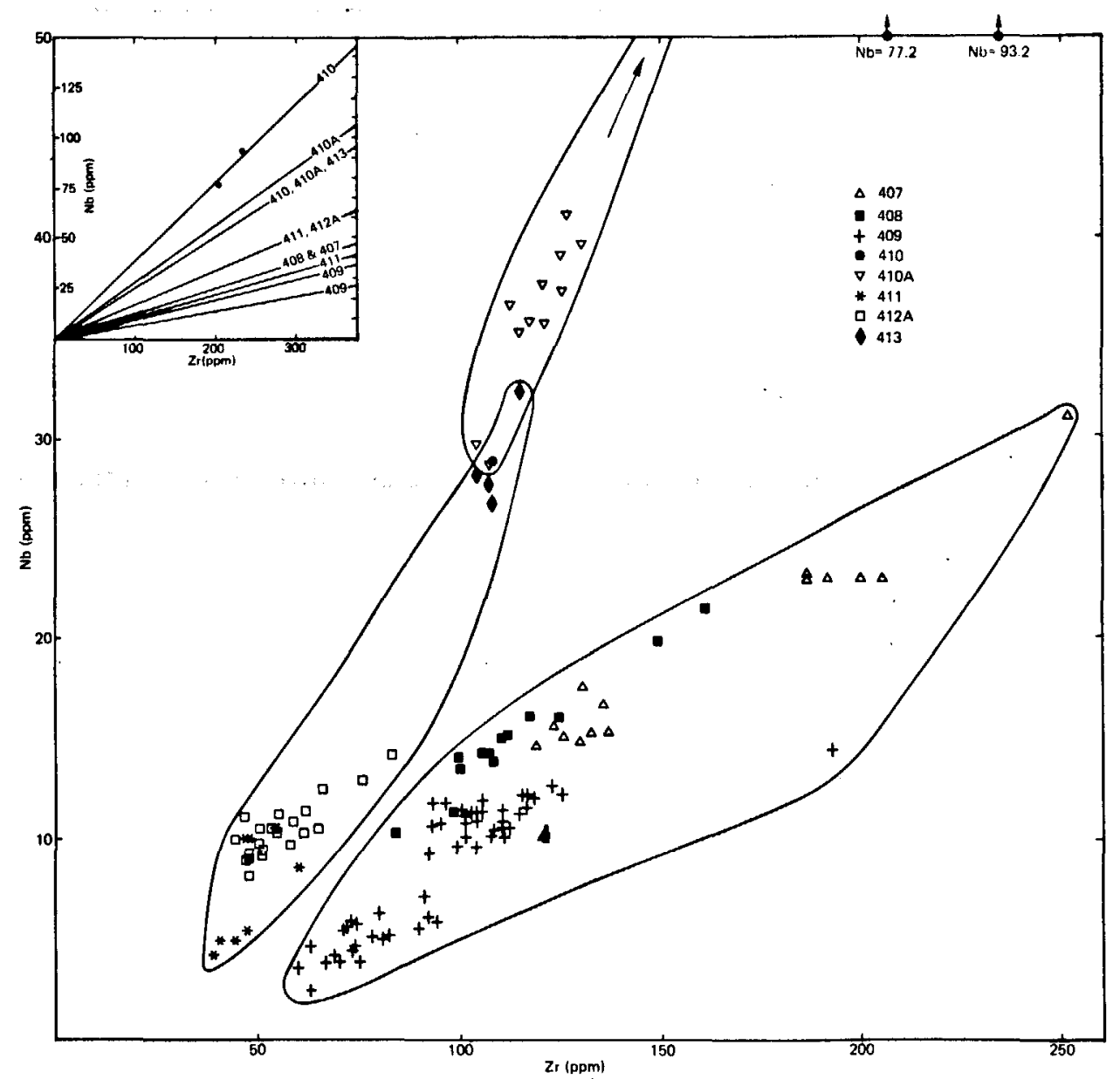

Figure 54. $\mathrm{Nb} / \mathrm{Zr}$ (ppm) plot for all analyzed samples from $\mathrm{Leg} 49.37^{\circ} \mathrm{N}, 45^{\circ} \mathrm{N}$, and $63^{\circ} \mathrm{N}$ areas are all distinguished by different contours.

to $60^{\circ} \mathrm{N}$, Carnegie Institute Washington Year Book, v. 74, p. 224-234.

Wood, D.A., 1976. Spatial and temporal variation in the trace element geochemistry of the eastern Iceland flood basalt succession, Journal of Geophysical Research, v. 81, p. $4353-4360$.
, in press. Major and trace element variations in the Tertiary lavas of eastern Iceland with respect to the Iceland geochemical anomaly, Journal of Petrology.

Wright, T.L. and Doherty, P.C., 1970. A linear programming and least squares computer method for solving petrologic mixing problems, Geological Society of America Bulletin, v. 81, p. $1995-2008$. 

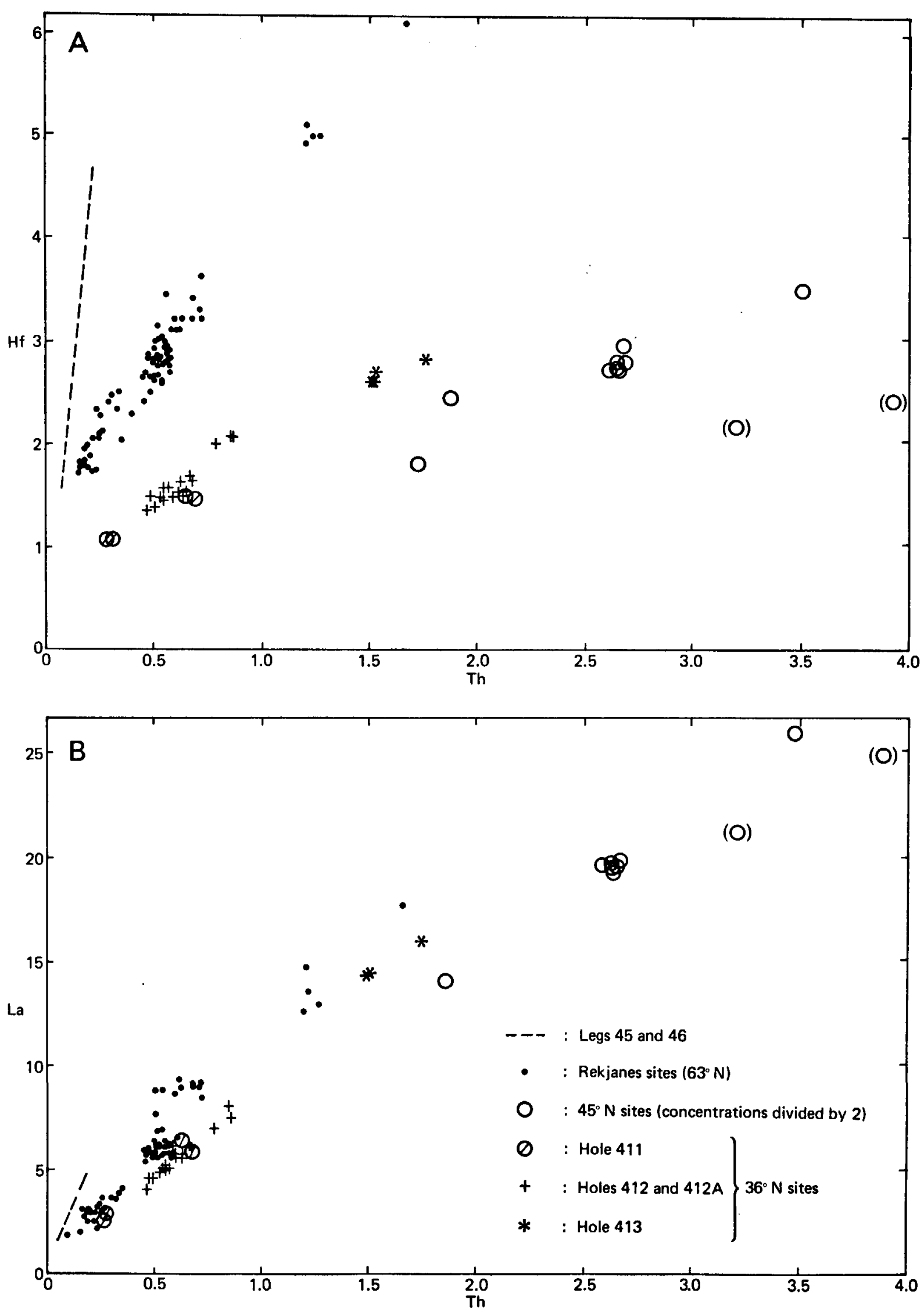

Figure 55. Hf/Th and La/Th (ppm) plots for analyzed samples from Leg 49, compared with Legs 45 and 46 (Bougault et al., 1978). 
TABLE 25

Least-Squares Crystal Fractionation Solution for Cycle 2 Hole 412A

\begin{tabular}{|c|c|c|c|c|c|c|c|}
\hline & $\begin{array}{c}\text { Deriv. } \\
412 \mathrm{~A}-4-1 \text {, } \\
20-25 \mathrm{~cm}\end{array}$ & $\operatorname{cpx}$ & ol & pl & $\begin{array}{c}\text { Parent } \\
412 \mathrm{~A}-11-2, \\
17-21 \mathrm{~cm}\end{array}$ & $\begin{array}{c}\text { Parent } \\
\text { calculated }\end{array}$ & Residuals \\
\hline $\mathrm{SiO}_{2}$ & 50.87 & 53.92 & 40.22 & 48.93 & 50.73 & 50.73 & 0.00 \\
\hline $\mathrm{TiO}_{2}$ & 1.30 & 0.22 & - & - & 0.90 & 1.00 & 0.10 \\
\hline $\mathrm{Al}_{2} \mathrm{O}_{3}$ & 14.77 & 2.52 & - & 32.42 & 15.29 & 15.32 & 0.03 \\
\hline $\mathrm{FeO}^{*}$ & 10.53 & 4.37 & 14.90 & 0.57 & 8.73 & 8.77 & 0.05 \\
\hline $\mathrm{MnO}$ & 0.18 & - & 0.40 & - & 0.15 & 0.15 & 0.00 \\
\hline $\mathrm{MgO}$ & 7.87 & 18.18 & 44.17 & - & 8.77 & 8.77 & 0.00 \\
\hline $\mathrm{CaO}$ & 11.88 & 20.78 & 0.32 & 15.96 & 13.03 & 13.06 & 0.06 \\
\hline $\mathrm{Na}_{2} \mathrm{O}$ & 2.24 & - & - & 2.12 & 2.18 & 1.94 & 0.23 \\
\hline $\mathrm{K}_{2} \mathrm{O}$ & 0.19 & - & - & - & 0.12 & 0.15 & 0.03 \\
\hline $\mathrm{P}_{2} \mathrm{O}_{5}$ & 0.15 & - & - & - & 0.10 & 0.11 & 0.01 \\
\hline \multicolumn{8}{|l|}{ Note: } \\
\hline $\begin{array}{l}\text { Mix } \\
\Sigma r^{2}= \\
\text { Diops } \\
\text { Olivir } \\
\text { An } 80\end{array}$ & $\begin{array}{l}75.24 \\
0696 \text {. } \\
\text { ic augite } \\
-412 \mathrm{~A}-3 \text { - } \\
\text { alculated (c }\end{array}$ & $\begin{array}{r}112-14 \\
36-40 \\
\text { Table }\end{array}$ & (io & $\mathrm{Mg} / \mathrm{Mg}$ & $\begin{array}{l}\mathrm{ic} \mathrm{Mg} / \mathrm{Mg} \\
\mathrm{e}=0.84 \text {, }\end{array}$ & $\begin{array}{l}e=0.88 \\
\text { le } 23) .\end{array}$ & loclase - \\
\hline
\end{tabular}

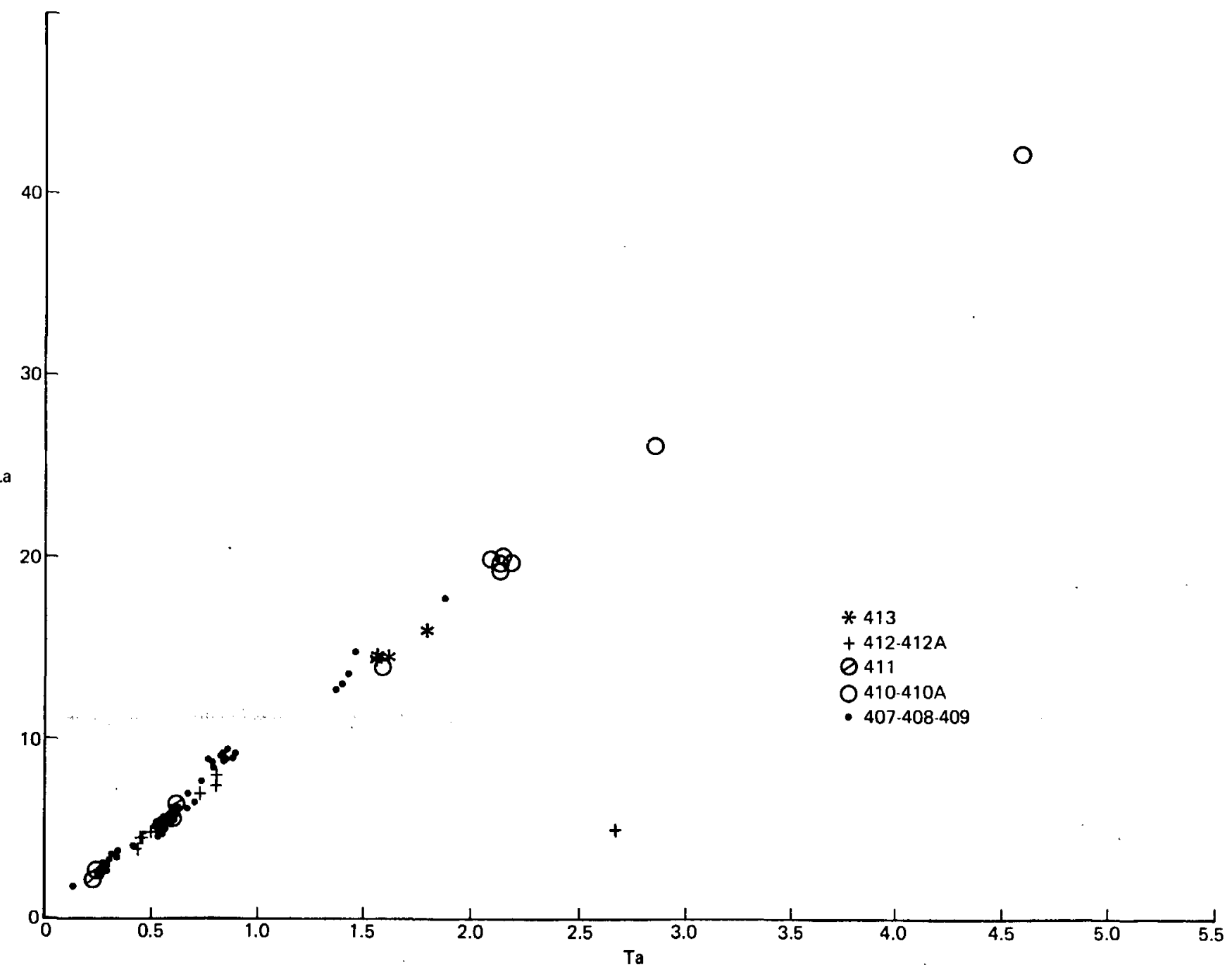

Figure 56. La/Ta plot for all analyzed samples from Leg 49. 

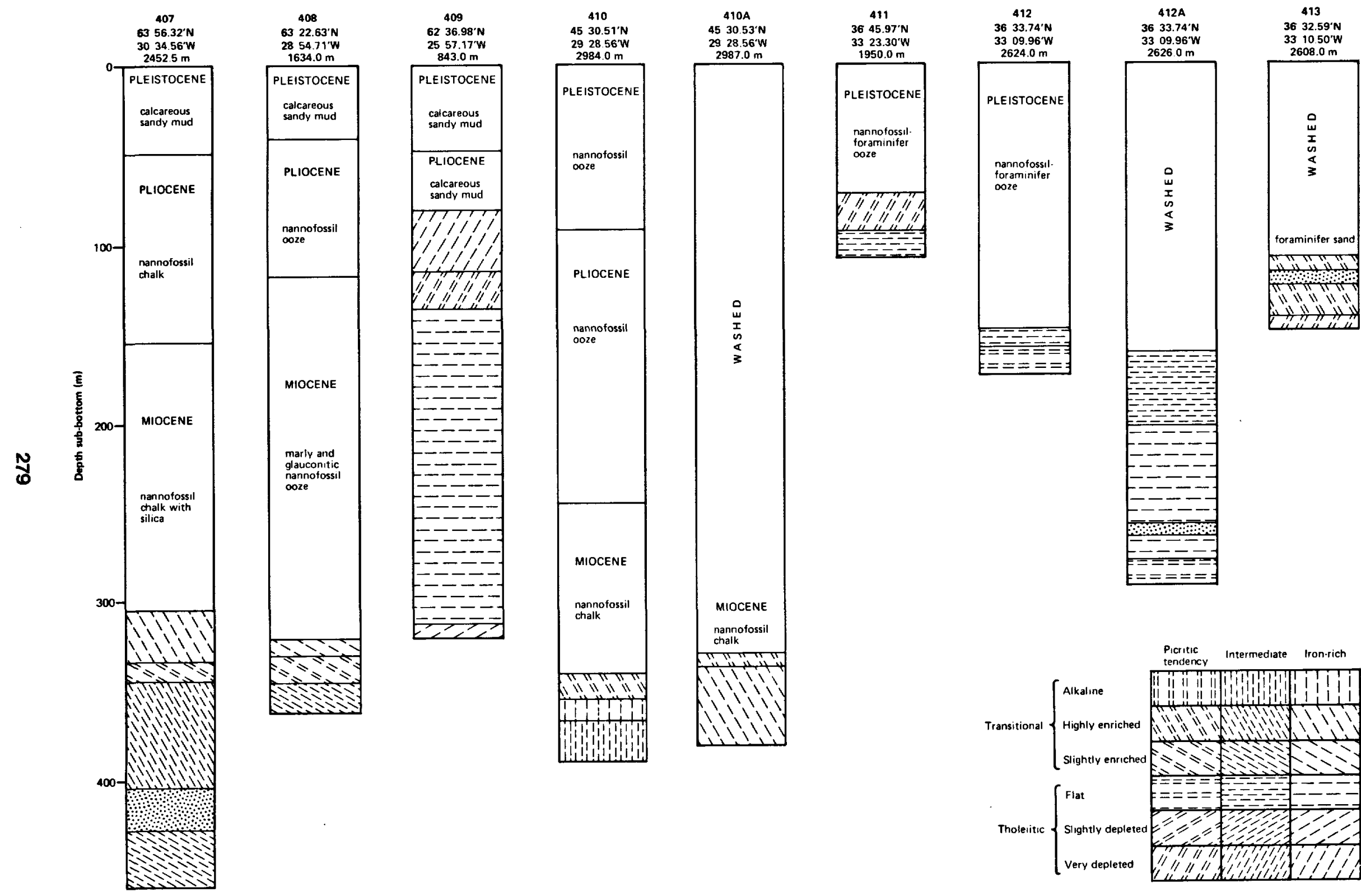

Figure 57. Simplified lithostratigraphic sections of Leg 49 holes. Major geochemical units are illustrated. 


\section{PLATE 1}

Photomicrographs* of Some Leg 49 Basalts and Basaltic Glasses From the $63^{\circ} \mathrm{N}$ and $45^{\circ} \mathrm{N}$ Sites

Figure 1 Field of view is $3 \times 4 \mathrm{~mm}$ (crossed polars). Sample 407-36-3, 60-62 cm. Zoned plagioclase phenocryst with very calcic core (Ang4, Table 1) in a variolitic groundmass.

Figure 2 Field of view is $0.75 \times 1 \mathrm{~mm}$ (plane polarized light). Sample 407-39-1, 55-59 $\mathrm{cm}$. Plagioclase laths $\left(\sim\right.$ Ant5 $\left._{7}\right)$ in a quenched groundmass.

Figure 3 Field of view is $3 \times 4 \mathrm{~mm}$ (plane polarized light). Sample $407-46-4,3-5 \mathrm{~cm}$. Fresh glassy pillow selvage with sparse olivine (Foso, Table 4) and plagioclase ( Anso) phenocrysts. The olivine phenocryst contains rare titaniferous magnesiochromites (Table 5). The glass becomes progressively more palagonitized away from the pillow margin, and is cut by $\mathrm{K}$-rich zeolite veins (cf. Pritchard et al., this volume).

Figure 4 Field of view is $3 \times 4 \mathrm{~mm}$ (plane polarized light). Sample 409-7-6, 38-40 cm. Olivine phenocryst (Fos 1, Table 10) in the fresh glassy contact between the uppermost basalt and sediment of this hole.

Figure 5 Field of view is $3 \times 4 \mathrm{~mm}$ (plane polarized light). Sample 410-39-1, 90-92 cm. Fresh to palagonitized glassy selvage of a basalt block in the upper breccia unit of this hole. The glass contains rare olivine phenocrysts ( $\sim$ Fos8- 86).

Figure 6 Field of view is $3 \times 4 \mathrm{~mm}$ (plane polarized light). Sample 410A-2-5, 11-14 cm. Fresh glassy selvage with rare olivine phenocrysts (Fos7, Table 16), showing typical quenched forms.

*Photomicrographs were taken by DAW on a Zeiss microscope using FP4 film at ASA 125 
Plate 1
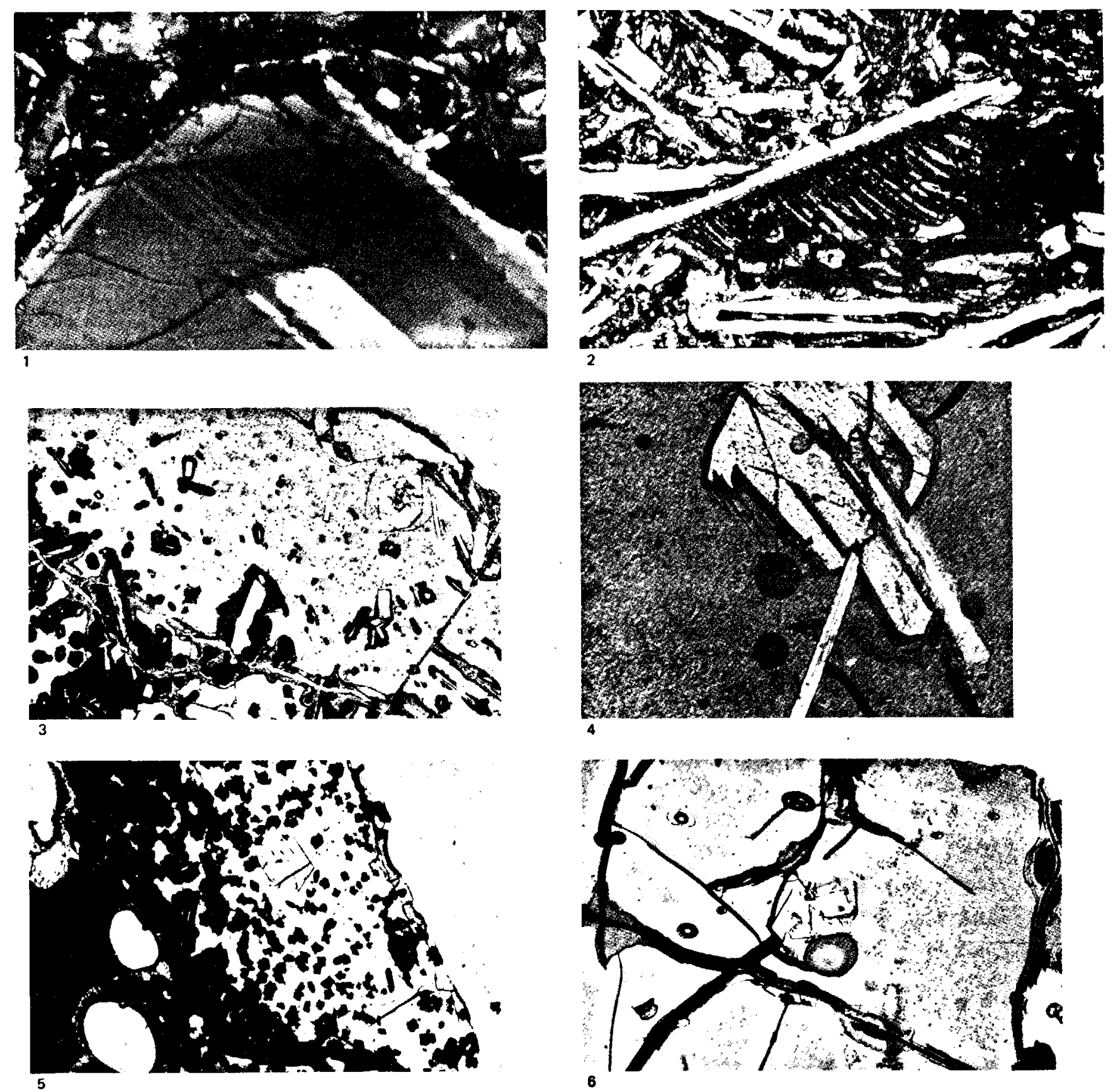
PLATE 2

Photomicrographs of Some Leg 49 Basalts From the $37^{\circ} \mathrm{N}$ Sites

Figure 1 Field of view is $3 \times 4 \mathrm{~mm}$ (plane polarized light). Sample 411-1-1, 32-34 cm. Olivine phenocrysts (Foss. Table 17) with abundant magnesiochromite inclusions (Table 18) in a very fine grained, glassy groundmass.

Figure 2 Field of view is $3 \times 4 \mathrm{~mm}$ (plane polarized light). Sample 411-3-1, 134-136 cm. Zoned plagioclase megacryst with a partially resorbed calcic (Ans9, Table 19) core in a very fine grained, glassy groundmass.

Figure 3 Field of view is $3 \times 4 \mathrm{~mm}$ (plane polarized light). Sample 412-15-1, 50-56 cm. Zoned plagioclase megacryst with partially resorbed, very calcic (Angi, Table 22) core in a coarsely plagioclase, clinopyroxene, and olivine phyric basalt.

Figure 4 Field of view is $3 \times 4 \mathrm{~mm}$ (plane polarized light). Sample 412A-2-1, 20-22 cm. Zoned plagioclase megacryst with a partially resorbed calcic (Ango, Table 22) core in a coarsely plagioclase, clinopyroxene, and olivine phyric basalt. The distribution of inclusions in the megacryst distinguish the different stages in its growth.

Figure 5 Field of view of $0.75 \times 1 \mathrm{~mm}$ (plane polarized light). Sample 412A-9-1, 70-72 cm. Olivine phenocryst (Fogo) with large magnesiochromite inclusions (Table 24).

Figure 6 Field of view is $3 \times 4 \mathrm{~mm}$ (plane polarized light). Sample 413-5-1, 45-50 cm. Olivine phenocrysts (Fo87, Table 23) in a "feathery" groundmass of plagioclase, olivine, and glass. The olivine phenocrysts contain rare magnesiochromite inclusions (Table 24). 
PLATE 2
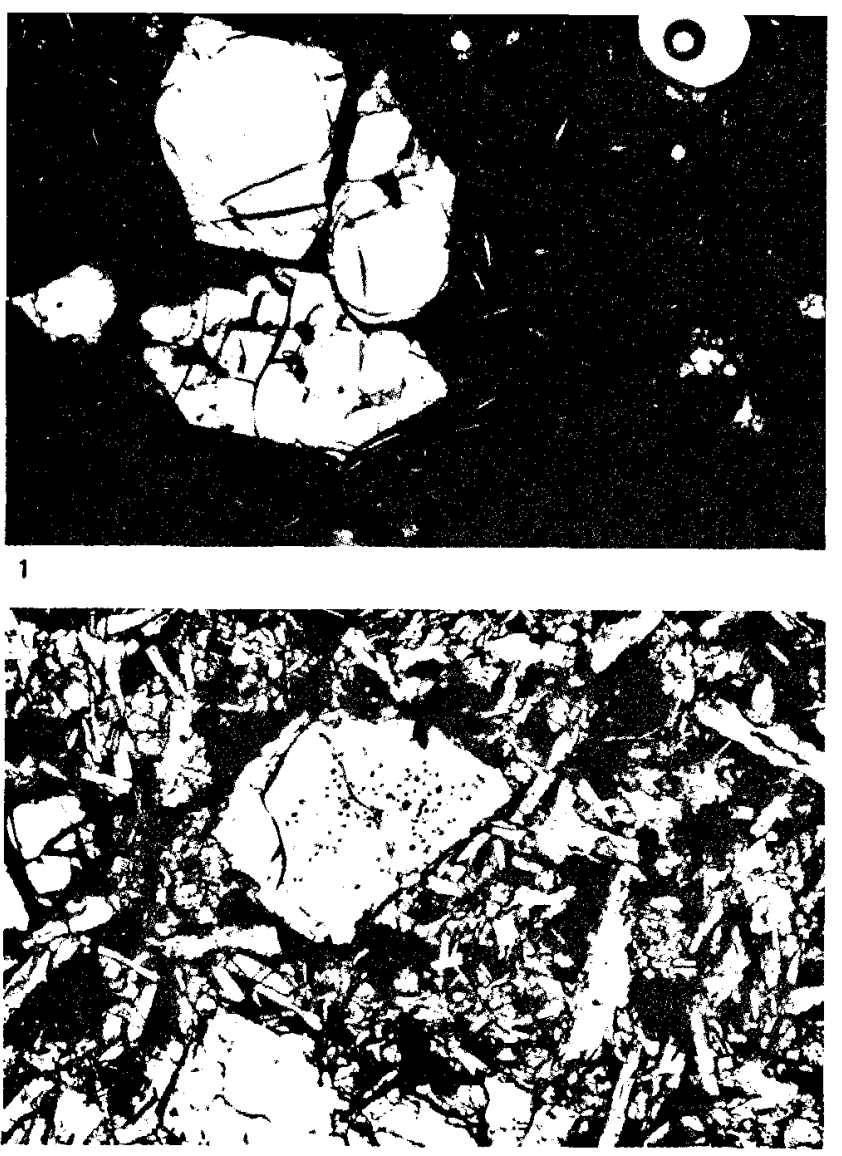
3

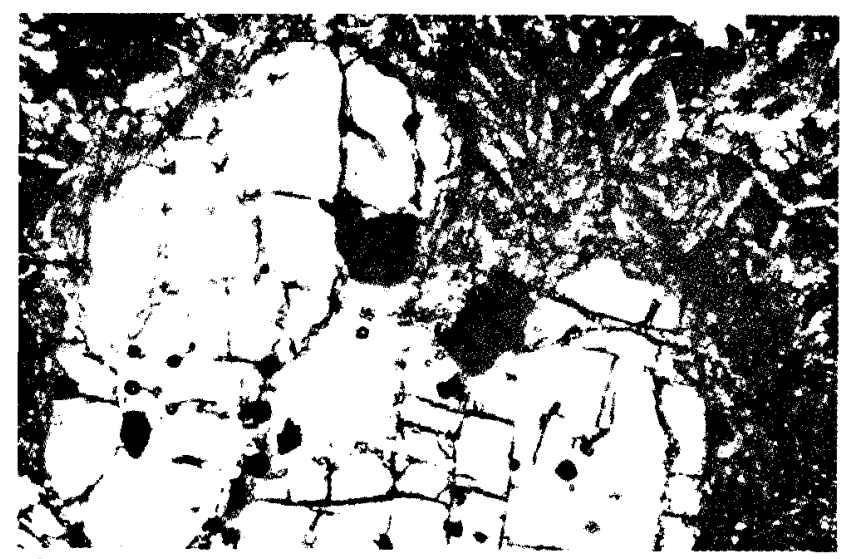

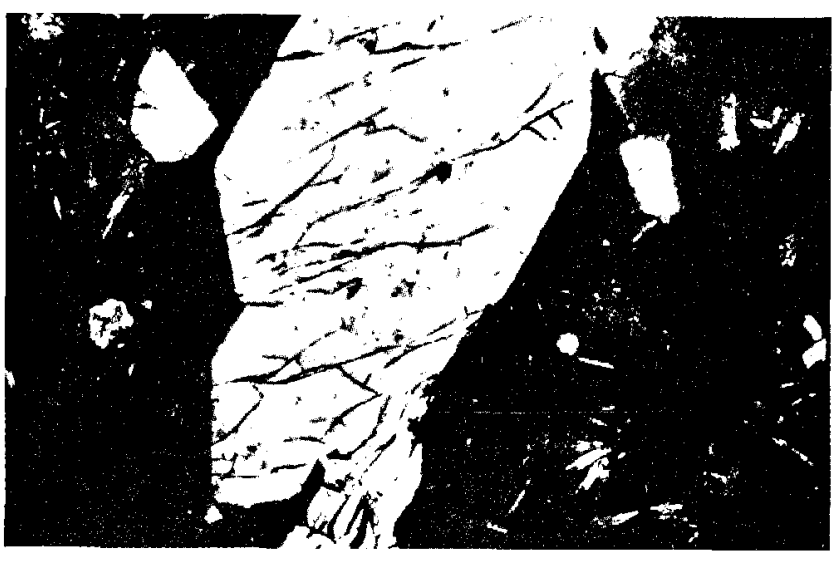

2

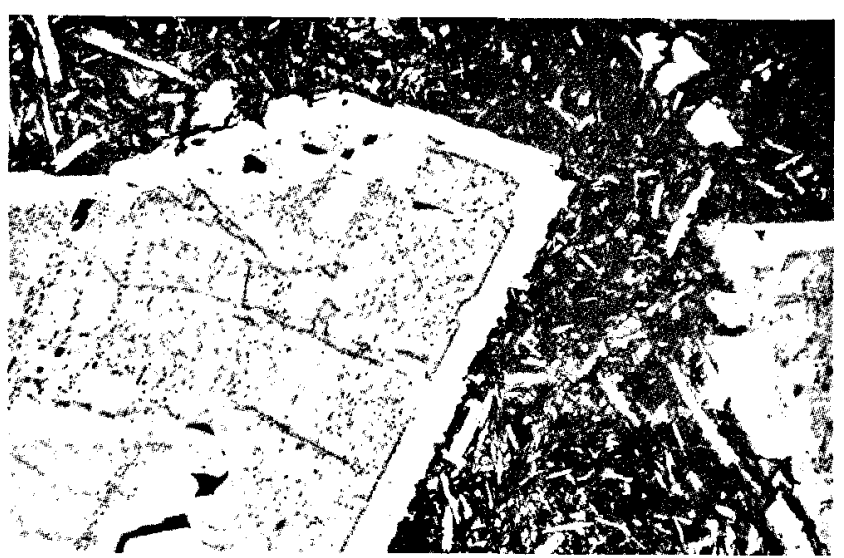

4

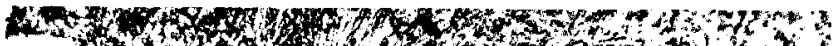

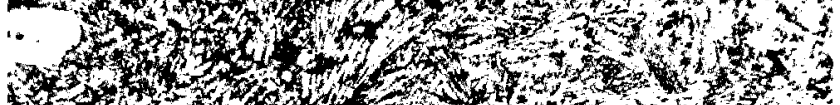

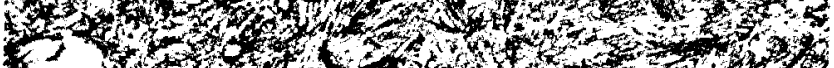

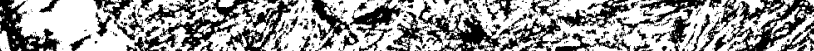

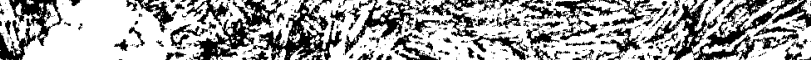

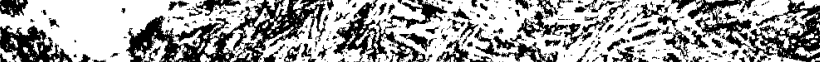

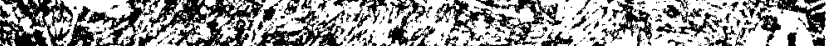

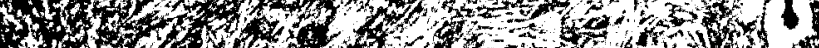

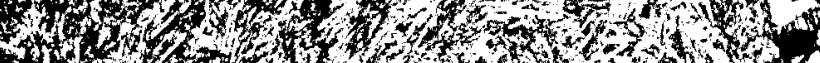

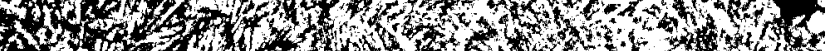

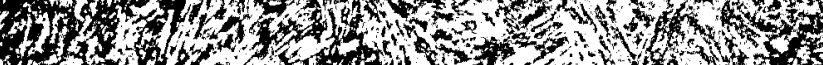

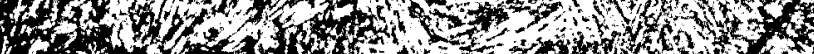
6 